Portland State University

PDXScholar

1986

\title{
A groundwater flow model of the aquifer intercommunication area, Hanford site, Washington
}

\author{
Elizabeth Gail Simkover \\ Portland State University
}

Follow this and additional works at: https://pdxscholar.library.pdx.edu/open_access_etds

Part of the Geology Commons, and the Hydrology Commons

Let us know how access to this document benefits you.

\section{Recommended Citation}

Simkover, Elizabeth Gail, "A groundwater flow model of the aquifer intercommunication area, Hanford site, Washington" (1986). Dissertations and Theses. Paper 3690.

https://doi.org/10.15760/etd.5574

This Thesis is brought to you for free and open access. It has been accepted for inclusion in Dissertations and Theses by an authorized administrator of PDXScholar. Please contact us if we can make this document more accessible: pdxscholar@pdx.edu. 
AN ABSTRACT FOR THE THESIS OF Elizabeth Gail Simkover for the Master of Science in Geology presented December 8, 1986.

Title: A Groundwater Flow Model of the Aquifer Intercommunication Area, Hanford Site, Washington.

APPROVED BY MEMBERS OF THE THESIS COMMITTEE:

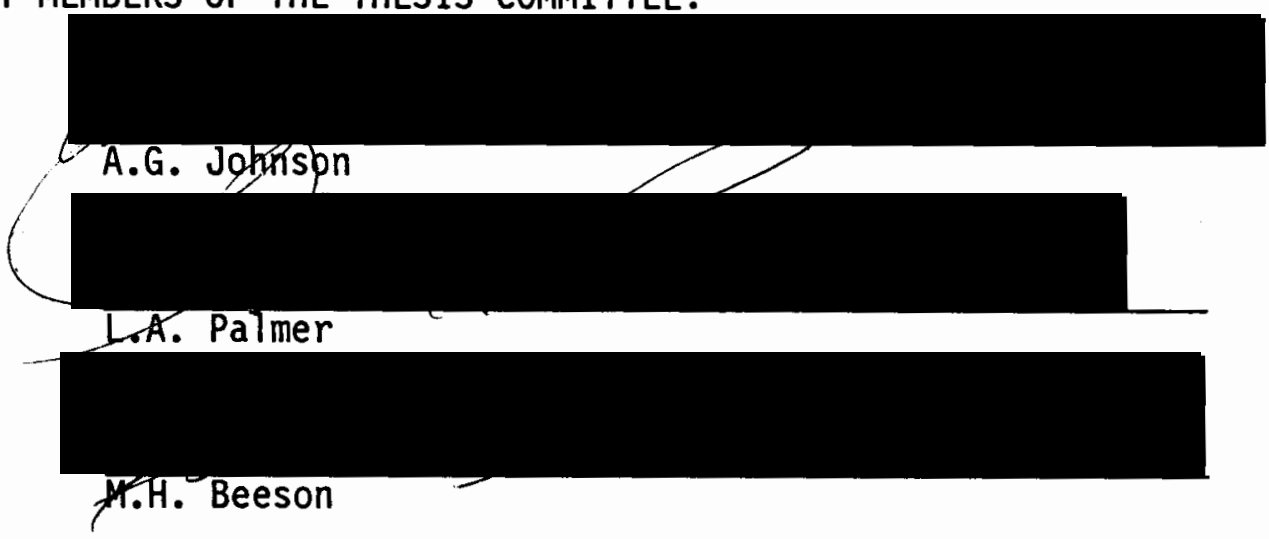

Intercommunication has been identified between the unconfined and uppermost confined aquifer systems underlying a portion of the U.S. Department of Energy's Hanford Site. Erosional thinning and fracturing of the basalt confining layer within the study area allows physical contact between the two aquifers, but the vertical hydraulic gradient (a required driving force) is small. To better conceptualize the distribution and volume of the leakage occuring between the aquifer systems, this study investigates the confined Rattlesnake Ridge Aquifer flow system, which appears to be more sensitive to the vertical leakage than the overlying unconfined aquifer. 
The flow system of the Rattlesnake Ridge Aquifer is poorly understood. The flow direction of this aquifer in the study area is difficult to define because most of the wells used to obtain data are concentrated in one area. The complexity of the flow in the study area makes extrapolation from these data points difficult.

Several scenarios are formulated to describe plausible hydrogeologic settings that could produce the confined flow pattern observed. These scenarios include recharge to the aquifer derived from leakage from the overlying unconfined aquifer and the underlying deep confined aquifer system. Leakage amounts were computed from estimations of vertical head differentials between the unconfined and confined aquifer and from hydraulic conductivity data of the basalt confining layer. The hydraulic conductivity values of the basalt are controlled by vertical fractures.

Results of modeling show that the observed flow configuration can be simulated as the westward flanks of a ground-water mound produced from leakage between the unconfined and confined aquifers. This implies that leakage through vertical fractures and erosional windows in the basalt can play an important role in the interpretation of the Rattlesnake Ridge Aquifer's flow system and in our understanding of aquifer intercommunication in the study area. 
A GROUNDWATER FLOW MODEL OF THE AQUIFER INTERCOMMUNICATION AREA, HANFORD SITE, WASHINGTON

\title{
by
}

\author{
ELIZABETH G. SIMKOVER
}

\begin{abstract}
A thesis submitted in partial fulfillment of the requirements for the degree of

MASTER OF SCIENCE

in

GEOLOGY
\end{abstract}

Portland State University

1986 
TO THE OFFICE OF GRADUATE STUDIES AND RESEARCH:

The members of the Committee approve the thesis of Elizabeth Gail Simkover presented December 8, 1986.

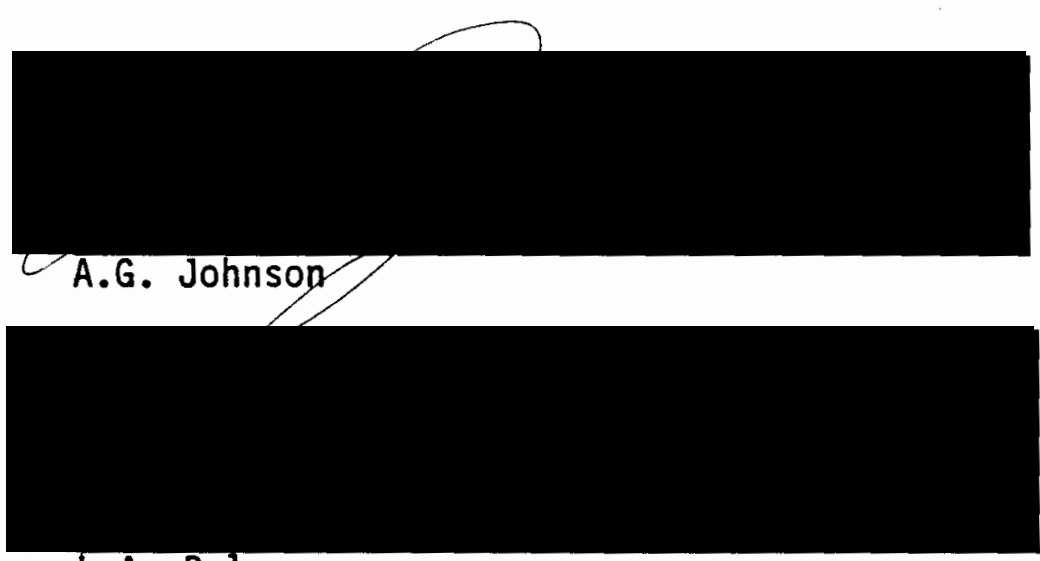

L.A. Palmer

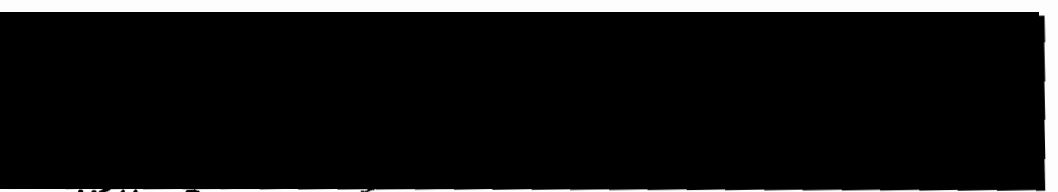

H.H. Beeson

APPROVED:

P.E. Hapmond, Head, Department of Geology

B. Ross, Uean of Graduate Studies and Research 


\section{ACKNOWLEDGEMENTS}

I would like to thank my advisor Dr. Ansel Johnson and the Northwest College and University Association for Science (University of Washington) which supported my research under Contract DE-AM0676-RL02225 with the U.S. Department of Energy. Special thanks to Gregg Petrie, Charlie Cole, and Randy Hagen. 


\section{PREFACE}

This study is divided into four sections. The INTRODUCTION section summarizes background information (i.e. hydrology, geology) to aid in the understanding of the problem definition and the methods of investigation. A more detailed description of the hydrogeology, that is required for model development, is presented in the CONCEPTUAL MODEL section. The study's plan and premises are found in the MOOEL STRATEGY AND ASSUMPTIONS section. MODEL CALIBRATION AND RESULTS present the simulated flow regime and leakage for a range of plausible input parameters. The development of the unconfined aquifer model is presented in Appendix $A$. The numerical model, presented in Appendix $B$, discusses the translation of this physical framework into mathematical terms, and how it is solved by a digital computer. A glossary of terms is included in Appendix C. 
TABLE OF CONTENTS

PAGE

ACKNOWLEDGEMENTS .........................

PREFACE ............................. iv

LIST OF TABLES ................................. vii

LIST OF FIGURES ...................................

\section{CHAPTER}

I INTRODUCTION ......................... 1

Background ................ 1

Site Description ............... 3

Climate

Geology

Hydrology

Previous Studies ................ 14

Ground-water Flow Modeling ....... 19

Methodology for Model Development

The Conceptual Model

The Numerical Model

Model Calibration and Validation

Problem Definition .......... 22

Purpose and Scope ............ 23

Code and Equipment .......... 25

II CONCEPTUAL MODEL . . . . . . . . . 27

Hydrogeological Properties ........ 27

Aquifer and Confining Layer Thicknesses

Hydraulic Conductivity/Transmissivity

Storage Coefficient 
Recharge/Discharge ........ 34

Flow System Geometry . . . . . . . 37

Ground Water Movement

Hydraulic Conductivity

Hydraulic Boundaries

III MODEL STRATEGIES AND ASSUMPTIONS . . . . . 44

Sensitivity Analysis ......... 45

Time Frame ............. 50

Boundary Conditions for the Confined Aquifer . . 53

Assumptions .............. 56

IV MODEL CALIBRATION AND RESULTS ........ 59

Input Parameters Adjusted in Calibration . . . . 59

Source Term

Interaquifer Transfer Coefficient

Hydraulic Conductivity

Boundary Conditions

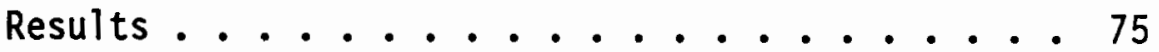

Summary and Conclusions ........ 86

Source Term

Interaquifer Transfer Coefficient

Hydraulic Conductivity of Interbed

Boundary Conditions

Recommendations ............ 90

REFERENCES CITED . . . . . . . . . . . . . 92

APPENDIX A . . . . . . . . . . . . . . 96

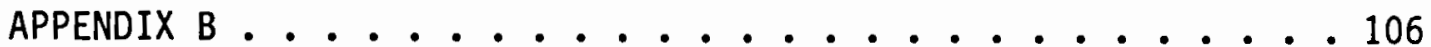

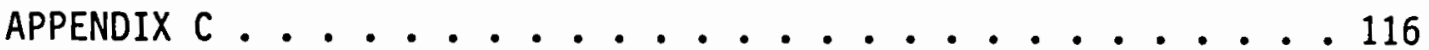




\section{LIST OF FIGURES}

FIGURE

PAGE

1. General Location Map of Study Area ......... 2

2. Stratigraphy of the Yakima Basalt Subgroup and the

Unconsolidated Sediments Within the Pasco Basin . . 7

3. Location of Topographic Ridges Defining the Structural

Boundary of the Pasco Basin ......... 9

4. Map of Faults and Folds Within the Study Area . . . . 10

5. Cross-section Depicting Unconfined and Confined Aquifers and Erosional Windows ......... 12

6. Potentiometric Surface Map of the Confined Aquifer . . 15

7. Hydraulic Conductivity of the Confined Aquifer . . . . 28

8. Isopach Map of the Rattlesnake Ridge Interbed . . . 30

9. Recharge/Discharge Components of the Rattlesnake

Ridge Aquifer ................. 35

10. Potentiometric Surfaces for Regional and Intermediate

Surfaces Flow Systems .......... 39

11. Observed Head Potentials Between the Mabton and Rattlesnake

Ridge Interbeds and the Unconfined Aquifer .... 40

12. Estimated Head Differentials Between the Confined and Unconfined Aquifers ......... 4 46

13. Water Level and Discharge Histories ......... 51 
14. Plot of Source Term Distribution of Upward

Leakage from Deep Confined Aquifer System . . . . 63

15. Isopach Map of the Elephant Mountain Member . . . . . 64

16. Plot of Source Term Distribution of Downward Leakage

from Disposal Ponds . . . . . . . . 68

17. Plot of Distribution of Interaquifer

Transfer Coefficient . . . . . . . 72

18. Plot of Residual Errors . . . . . . . . 77

19. Results of Run 27 with Boundary Conditions Derived from

Planar Extrapolation of Data Points . . . . . 83

20. Results of Run 19 with Boundary Conditions Derived from

Unconfined Aquifer Potentials . . . . . . 84

A.1. Water Table Map of the Hanford Site . . . . . . . 98

A.2. Water Table Map of the Study Area . . . . . . . . 99

A.3. Aquifer Bottom Surface . . . . . . . . . 101

A.4. Grid of Unconfined Aquifer .......... 103

A.5. Residual Error of Unconfined Model's Results ..... 105

B.1. Representative Elemental Volume Cube . . . . . . 108

B.2. Function Plot ......................... 111

B.3. Finite Difference Grid . . . . . . . . . 112

B.4. Model Grids ................ 115 


\section{LIST OF TABLES}

TABLE

PAGE

I Geology/Stratigraphy of the Unconfined and Uppermost

Confined Aquifers in the Separations Area ..... 5

II Geologic and Hydrologic Studies ........ 16

III Groundwater Modeling Studies . . . . . . . . 17

IV Ranges of Hydraulic Conductivity

in the Study Area ............. 32

V Summary of 28 Simulations Representing

Various Conditions ............. 48

VI Upward Leakage Values . . . . . . . . . 62

VII Downward Leakage Values ............ 67

VIII Values of Interaquifer Transfer Coefficient . . . . 71 


\title{
CHAPTER I
}

\section{INTRODUCTION}

\author{
BACKGROUND
}

The federally operated Hanford Site was set up in 1943, by the Manhattan District of the Corps of Engineers, to produce plutonium. The site contains $1476 \mathrm{sq}$. $\mathrm{km}$, just north of the town of Richland (Figure 1). Tasks conducted on the Hanford Site include the management of nuclear wastes from national sources. Rockwe1l Hanford Operations manages the chemical processing, waste storage, and waste disposal operations on the Hanford Site for the U.S. Dept. of Energy (DOE). Battelle Pacific Northwest Laboratory performs research tasks for Rockwell and DOE.

The Separations Area is the site of major liquid waste disposal for the Hanford Site (see Figure 1). This area contains the facilities for irradiated uranium fuels processing, plutonium separations, and the major radioactive waste storage and disposal. Liquid Wastes, primarily consisting of large volumes of cooling water carrying low level radioactive wastes, are released to surface radioactive waste management facilities.

The study area for this thesis is situated in the Separations Area. This location was chosen for study for two reasons: its proximity to the disposal area where liquid wastes perculate down to provide recharge to the unconfined aquifer, and to a Pleistocene 


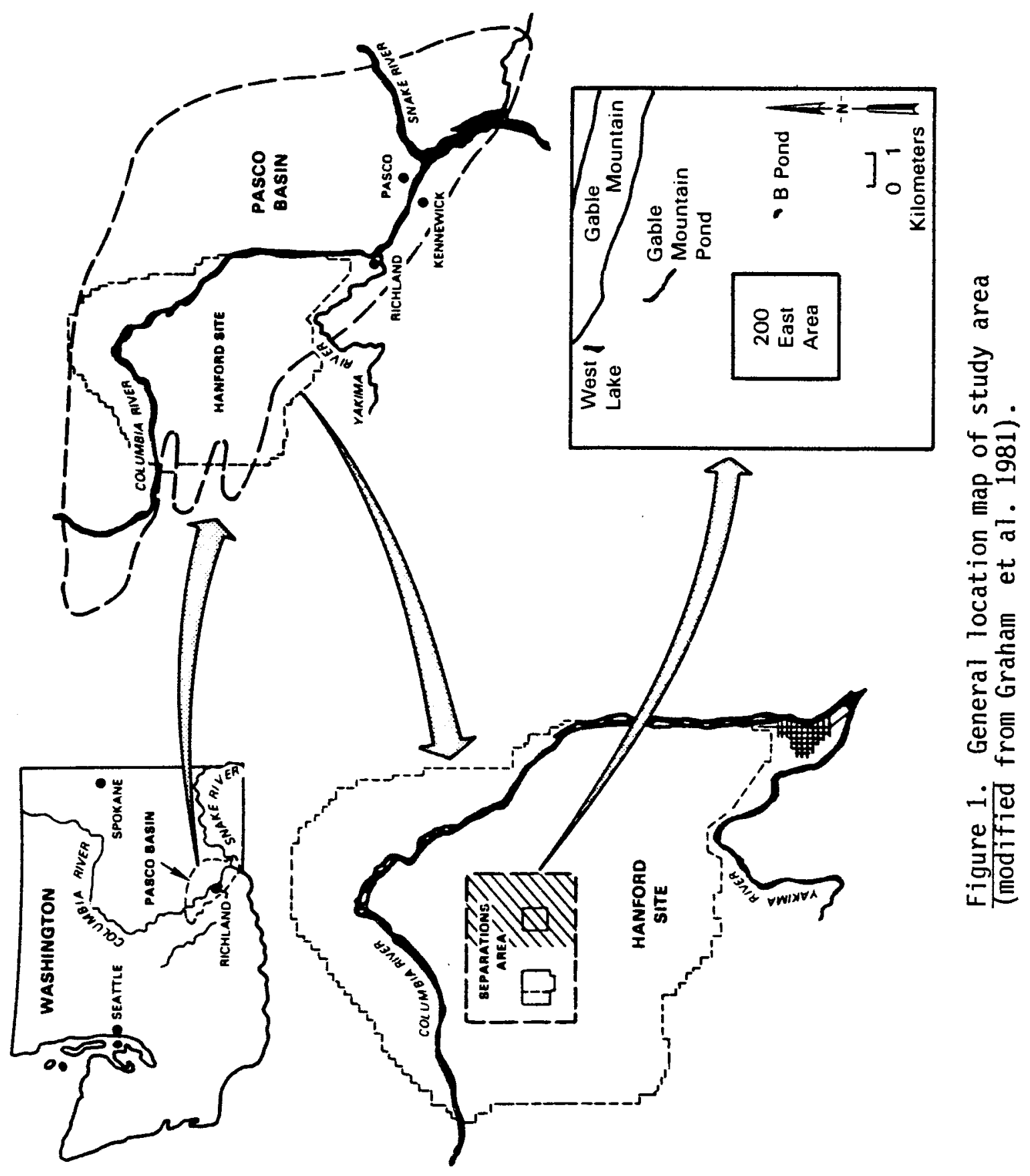


scabland channel, that eroded througn the site's upper most stratigraphic units (Gephart et al., 1976).

\section{SITE DESCRIPTION}

\section{Climate}

The Pasco Basin is classified as a semi-arid desert (Stone et al., 1972). Summers are normally hot and dry with July average maximum temperatures of $33.2 \mathrm{C}$, and average minimum temperatures of 16.1 degree $C$. Winters in the region are generally mild, with average maximum temperatures in January of 2.6 degree $C$ and average minimum temperatures of -5.5 degree $C$.

The climate in the Pasco Basin is dominated by the Cascade Range, which controls the regions temperature, winds, and precipitation. The range produces a rain shadow for the site, which only receives an average percipitation of 15 to $18 \mathrm{~cm}$. (Stone et al., 1972)

The climatological variables, precipitation and evaporation, can influence the groundwater system. Maximum precipitation occurs during months of low evaporation (37\% of annual precipitation occurs during the months of November, December and January) and maximum evaporation occurs during the months of low precipitation (10\% of annual precipitation occurs during the months of July, August, and September). Average pan evaporation is between 140 to $152 \mathrm{~cm}$ per year (Stone et a1., 1972). 
Geology

This study focuses on a portion of the Pasco Basin, a structural and topographic low within the Columbia Plateau, located in south-eastern Washington. The Pasco Basin contains fluvial plains and scabland features, with basalt anticlinal ridges as its boundaries. The stratigraphy is summarized in Table I. 


\section{TABLE I}

GEOLOGY/STRATIGRAPHY OF THE UNCONFINED AND UPPEPMOST CONFINED AQUIFER IN THE SEPARATIONS AREA

(modified from Last and Fecht, 1984)

\begin{tabular}{|c|c|c|c|c|}
\hline \multicolumn{3}{|c|}{$\begin{array}{l}\text { FOPMATION MEBER/ THICWNESS } \\
\text { INTERBED }\end{array}$} & LITHOLOGY & COMMENTS \\
\hline Hanford & $\begin{array}{l}\text { Pasco } \\
\text { Gravels }\end{array}$ & $20-90 \mathrm{~m}$ & $\begin{array}{l}\text { high energy facies- } \\
\text { variable size and } \\
\text { sorting of sand } \\
\text { and gravel }\end{array}$ & $\begin{array}{l}\text { found in basin's } \\
\text { center. low energy } \\
\text { facie not found in } \\
\text { study area. }\end{array}$ \\
\hline \multirow[t]{3}{*}{ Ringold } & Upper & 0 & \multirow{3}{*}{$\begin{array}{l}\text { low energy-silt } \\
\text { and sand } \\
\text { high energy-sand, } \\
\text { gravel. compact } \\
\text { low energy sand } \\
\text { silt, clay inter- } \\
\text { bedded gravel and } \\
\text { sand } \\
\text { high energy sand } \\
\text { gravel with silt. } \\
\text { poorly cemented. }\end{array}$} & \multirow{3}{*}{$\begin{array}{l}\text { generally not found } \\
\text { in study area. } \\
\text { thickens to SE and } \\
\text { west. east-central } \\
\text { only found in parts } \\
\text { of } 200 \text { West area. } \\
\text { Thickens to the } \\
\text { south } \\
\text { only found in south } \\
\text { and west portion } \\
\text { of area. Thickens } \\
\text { to the south. }\end{array}$} \\
\hline & Middle & $0-100 \mathrm{~m}$ & & \\
\hline & Lower & $0-30 m$ & & \\
\hline
\end{tabular}

Saddle Elephant 11-35m 7.7m-average thickness of uppenmost flow Mtn Mountain

Basalt (Elephant Mit II) 25m-average thickness of lowermost flow (Elephant Mnt I)

Ellens- Rattle- 1-21m sandwiched in the basalt burg snake Ridge (15m average thickness)

Saddle Pomona 56m avg. Thickens slightly to south Mtn thickness

Basalt

The Pasco Basin is one of several basins of the Columbia Plateau (Gephart et al., 1979). This downwarped region lies in the center of the main body of the Columbia River Basalt Group that extends from the Cascade Range eastward to the Rocky Mountains and from the Okanogan Highlands south to the mountains of central Oregon. 
Swanson et al., (1975) described the geological history. The tholeiitic flood basalts emanated from fissures to the east and south of the Pasco Basin. These flows accumulated in the downwarped area from 6 to 15.4 m.y.a. and form the bedrock for the region. Because the basalt in the basin may reach a thickness of over 3048 meters, knowledge of formations older then the Columbia River Basalt Group is limited.

The basin's basalt consists of three formations that are included in the Yakima Basalt Subgroup. They are: the Grande Ronde Basalt (14.5 to 15.4 m.y.a.), the Wanapum Basalt (13.6 to 14.5 m.y.a.) and the Saddle Mountains Basalt (6 to 13.6 m.y.a.) (Myers et al., 1979). Within the study area, the upper 250 meters consists of the Saddle Mountain Basalt. The stratigraphy of the basalt found in Pasco Basin is shown in Figure 2. The uppermost flow and interbed of this formation is of primary concern to this study.

The Ringold Formation (Pliocene) overlies the basalt bedrock (see Figure 2). It is a fluvial/lacustrine unit, deposited by streams and the shifting currents of shallow-lake environments. Within the Pasco Basin, the Ringold Formation has a maximum thickness of up to 370 meters (Tallman et al., 1979), contrasting to the Separations Area, where these sediments have a maximum thickness of less the 170 meters, due to erosion (Brown, 1959). The Ringold Formation is divided into four units based on lithology (Gephart et al., 1979)(see Table I). These units can be described as alternating high and low-energy facies, composed of gravel, sand, silt, and clay. The higher-energy sand and gravel sequence may represent deposition 


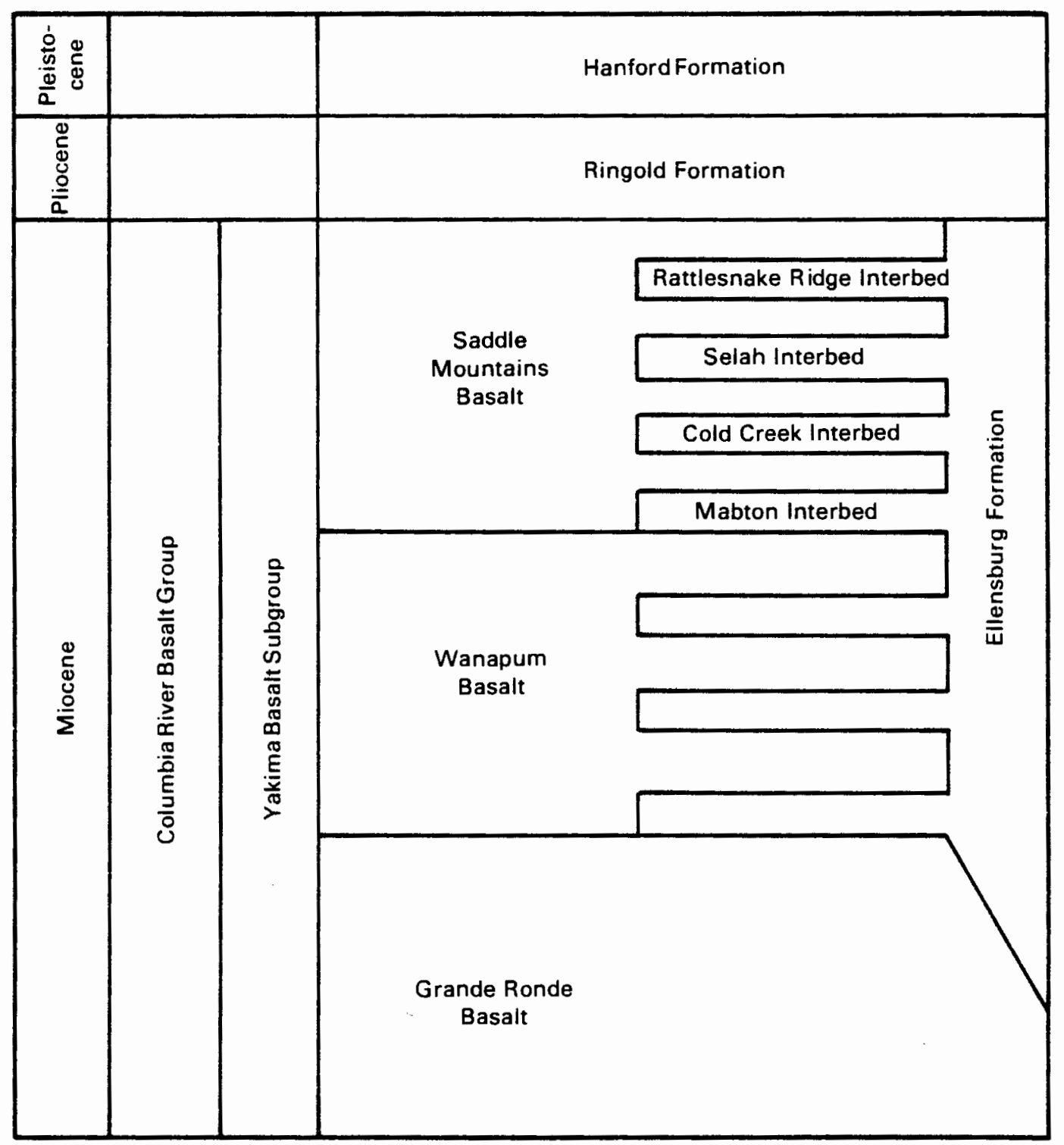

Figure 2. Stratigraphy of the Yakima Basalt Subgroup and the unconsolidated sediments within the Pasco Basin (modified from BWIP staff, 1982). 
in current-carrying portions of a lake, while the lower-energy silty and clayey sand characterizes deposition in quieter, shallower and marginal portions (Newcomb and Strand, 1953).

Portions of the Ringold Formation and the underlying basalt were locally eroded when catastropic floods of the Pleistocene glaciation period scoured channels in the Hanford Site (Bretz, 1959). The sediments of the Hanford Formation (informal name) were deposited when these flood waters were backed up to form glacial Lake Lewis (Newcomb and Strand, 1953). The slackwater sediments were deposited on the margins of the lake and were rhythmically bedded as silt and fine sand. Where the current was more rapid, near the center of the lake, gravels were deposited.

The basalt is folded in the Pasco Basin to produce a series of anticlines and synclines that generally trend east-west. A location map of these basalt ridges is shown in Figure 3 . The deformation initiated during the Miocene Epoch, is continuing today (Graham et al. 1981). The main anticlinal ridges to the west of the study area are the Yakima Ridge System; to the south are the Horse Heaven Hills; to the north are the Saddle Mountains; to the northwest is Umtanum Ridge; and to the southwest is Rattlesnake Mountain (see Figure 3). Gable Butte and Gable Mountain, both extensions of Umtanum Ridge, lie in the northern portion of the site. The Wahluke Syncline lies to the north of Umtanum/Gable Mountain Ridge and the Cold Creek and Pasco Synclines lie to the south. Folds located within the study site are shown in Figure 4. Faults in the region are generally related to the anticlines, responding to a north-south compressional 


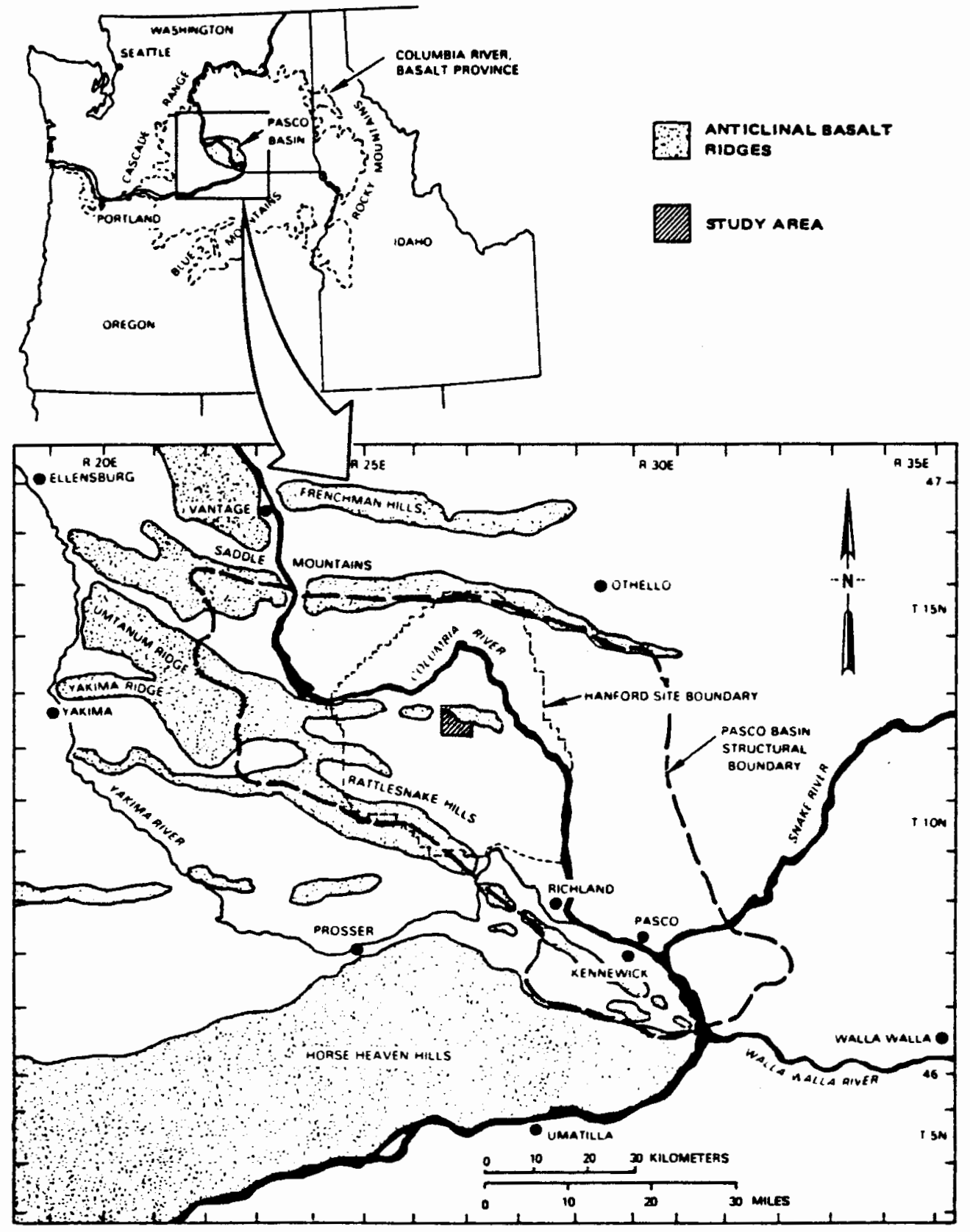

Figure 3. Location of topographic ridges defining the structura 1 boundary of the Pasco Basin (modified from Graham, 1984). 


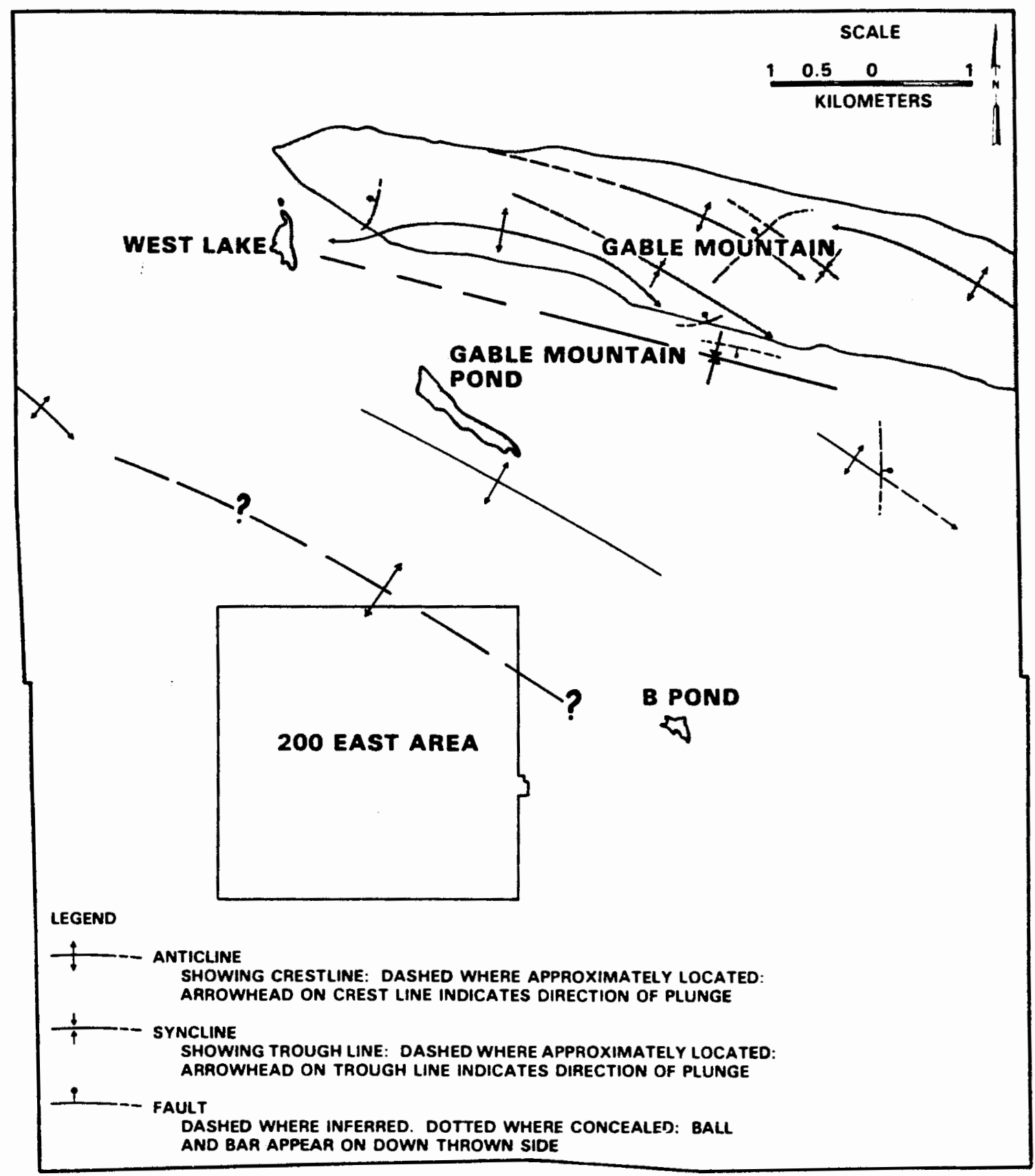

Figure 4. Map of faults and foids within the study area (modified from Graham, 1984). 
folds, responding to a north-south compressional regional stress regime (see Figure 4). These faults are generally of a thrust type which strike sub-parallel to the axes of the folds. The synclinal folds are relatively undeformed.

\section{Hydrology}

Four hydrologic systems occur in the Pasco Basin. They are the surface-water bodies, the unsaturated zone, the unconfined aquifer system, and the confined aquifer system. Figure 5 illustrates the relationship between the aquifer systems with two cross-sections through the study area.

The Pasco Basin receives water from the Columbia, the Snake, and the Yakima Rivers. The Snake and the Yakima Rivers join the Columbia River near the Tri-Cities, south of the study site (see location map, Figure 1). The U.S. Geological Survey (Newcomb, et a1., 1972) estimated that the average discharge from the Columbia River is 120,400 cubic feet per second, for a 60-year period, taken north of the Hanford Site. West Lake, an expression of the groundwater table, is located in the northwest corner of the study area (see Figure 1). Prior to artificial recharge from nearby waste disposal operations, West Lake was filled only during the wet months. An increased hydraulic gradient from this recharge now keeps the lake saturated during the entire year.

The unsaturated (vadose) zone has a thickness up to one hundred meters within the study area (Gephart et al., 1979). It is defined by the groundwater table and the land surface. This zone is in the Hanford and/or Ringold Formations. 


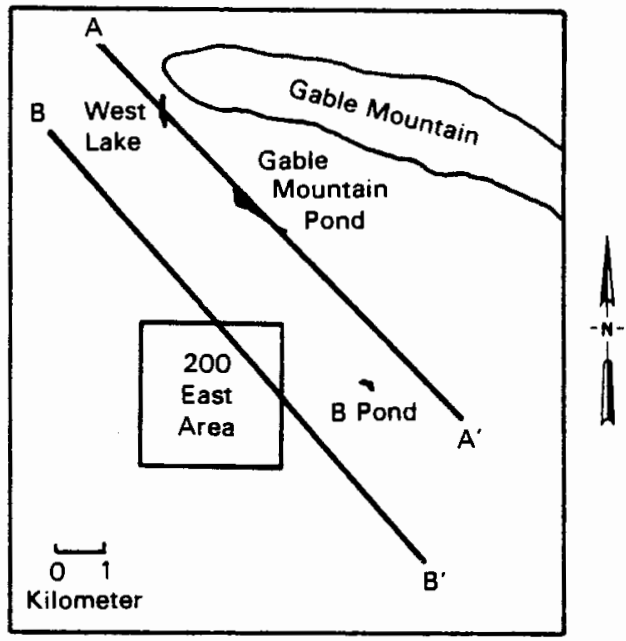

Rattlesnake

Ridge Aquifer
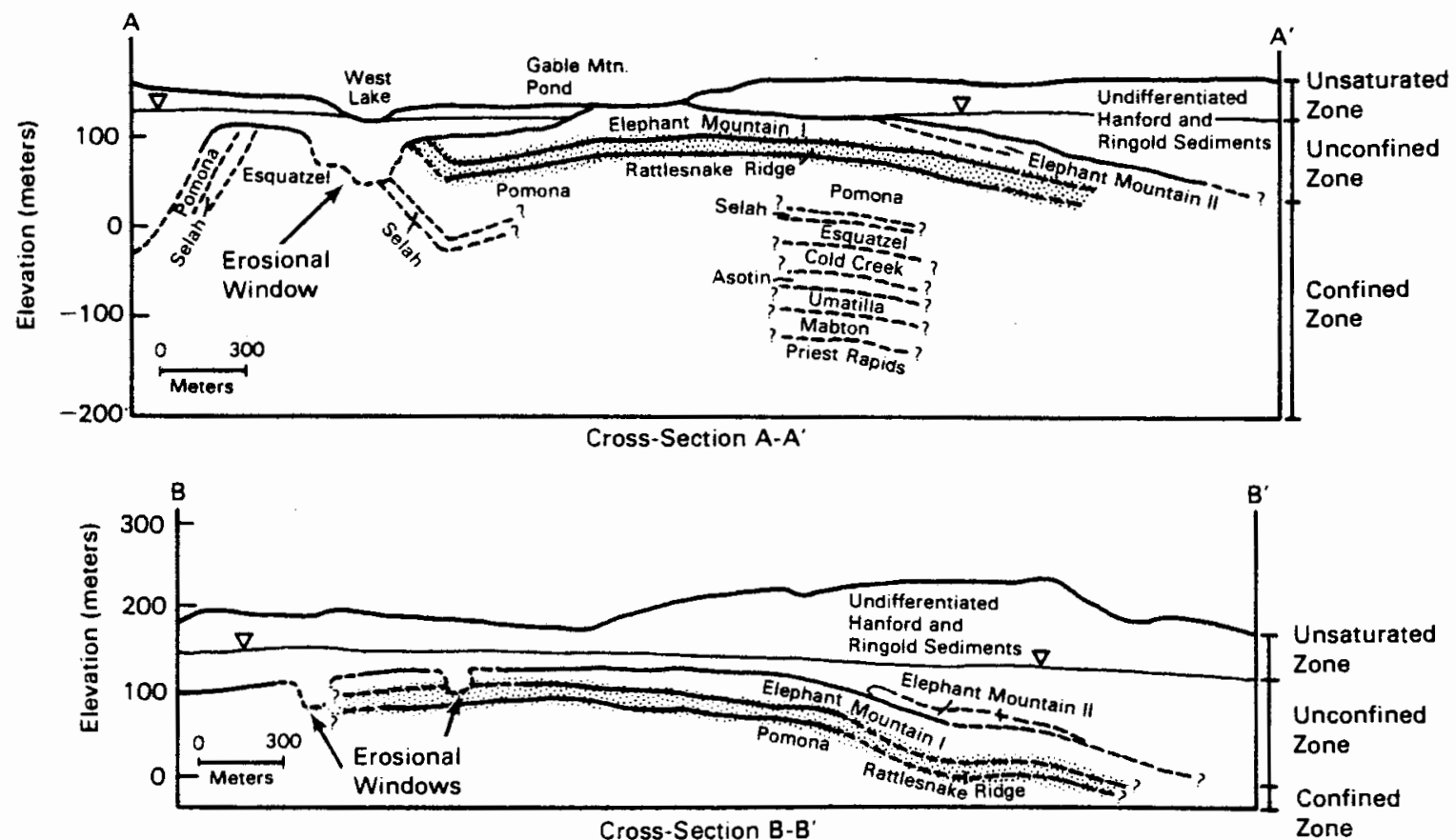

Figure 5. Cross-sections depicting the unconfined and confined aquifers and erosional windows (modified from Graham, 1984). 
The unconfined aquifer is composed of Ringold and/or Hanford sediments. It has a thickness of over 70 meters within the study area, and thins to zero where the sediments pinch out along the flanks of basalt ridges (Graham, 1981).

The unconfined aquifer underlying the study site is mostly recharged from liquid waste disposal operations. This recharge amounts to approximately ten times the natural recharge flowing into the area (Graham et a1., 1981). The regional flow direction is to the southeast, where the aquifer eventually discharges into the Columbia River (flow directions can be interpreted from the equipotential map of Figure A.1.1.). A smaller flow component discharges to the Columbia River to the north, past Gable Mountain. A more detailed description of the unconfined aquifer is presented in Appendix A.

The confined aquifer system mainly consists of the permeable flow tops and interbeds of the Columbia River Basalt Group. The uppermost Rattlesnake Ridge aquifer, of primary concern in this study, consists of the flow bottom of the Elephant Mountain Basalt, the Rattlesnake Interbed, the flow top of the Pomona Basalt, (see Table I and Figure 5). The thickness of this aquifer ranges from 24 to 34 meters near the Separations Area (Basalt Waste Isolation Project (BWIP) staff, 1982). The dense portion of the Elephant Mountain basalt flow acts as a confining layer which separates the unconfined aquifer and the Rattlesnake Ridge aquifer. Columnar jointing in the basalt can produce pathways for leakage between the two aquifers. Structural deformation may enhance the openings of 
these fractures. However, these fractures are often filled with secondary mineralization (Last and Fecht, 1984).

Recharge to this uppermost confined aquifer occurs in the highlands that bound the basin on west, north, and northeast where the interflow zones structurally intersect the land surface (Graham, 1984). This aquifer has two flow components, which are similar to the unconfined aquifer. The predominate flow direction is to the southeast, south of Richland. The smaller component flows to the north, discharging into the unconfined aquifer in the West Lake area (Figure 6).

\section{PREVIOUS STUDIES}

In Eastern Washington, geohydrological investigations began about the turn of the century, assessing the availability of groundwater resources. Numerous geohydrological investigations have been done since waste disposal practices became the responsibility of the Atomic Energy commission in the late 1940's. Tables II and III list representative reports that of the various geologic, hydrologic, and groundwater modeling studies of the Hanford Site.

A review of the geology of the region was given in Myers and Price (1979). A more detailed account of the geology of the Separations Area is given by Fecht (1978b), Tallman et al. (1979), and Last and Fecht (1984). Geophysical studies of the Separations Area were conducted by Richard (1976), Myers and Price (1981), and Moore (1982). A general overview of the hydrology of the entire region was given in Gephart et al. (1979), while a more complete 


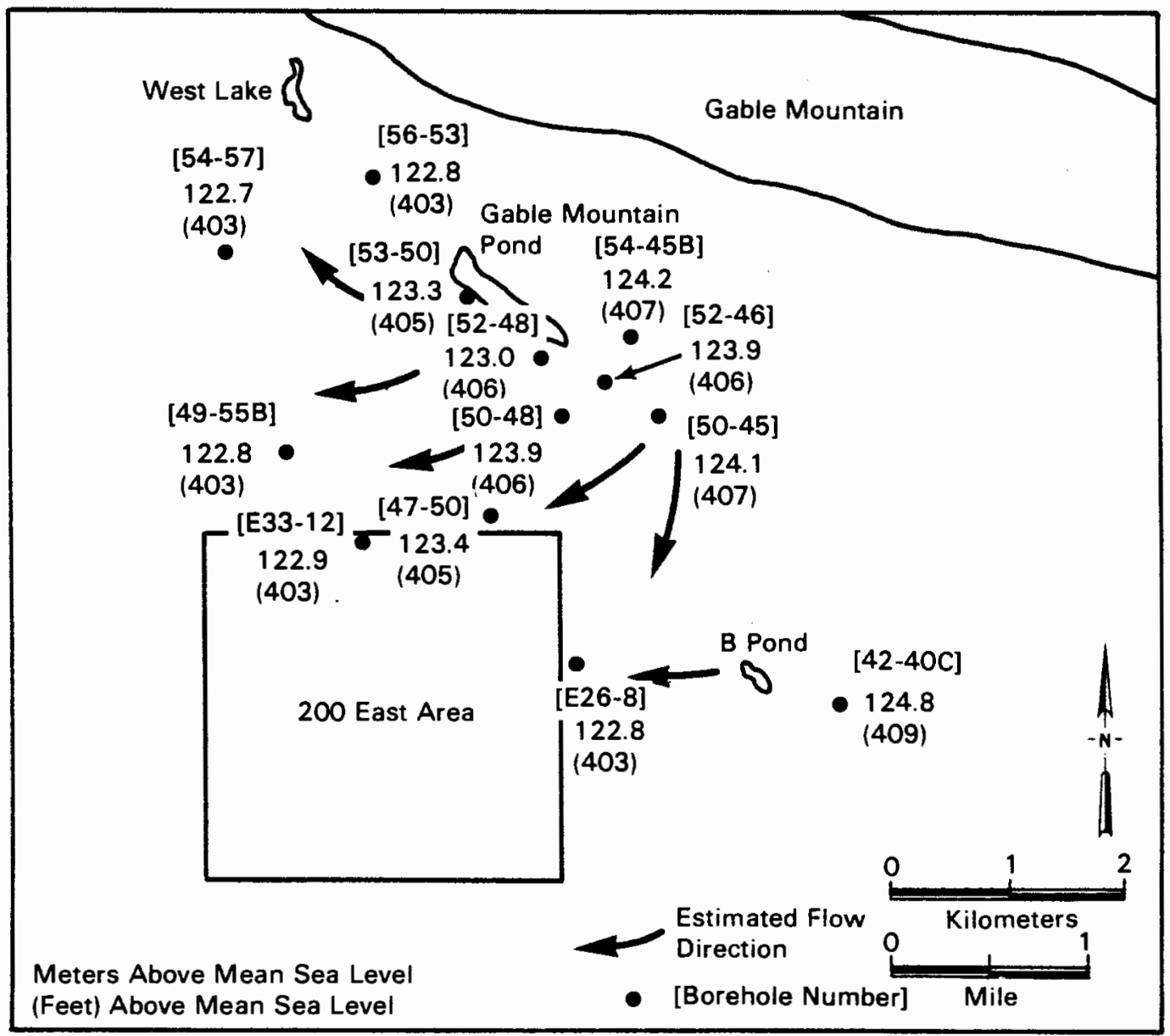

Figure 6. Potentiometric surface map of the confined aquifer, 1982-83. 
TABLE II

GEOLOGIC AND HYDROLOGIC STUDIES

- GEOLOGY-

1949 Parker, G.G. and Piper, A.M.; U.S. Geol. Survey, Interim Report No.1 WP-7, Geology and Hydrologic Features of the Richland Area, Washington, Relevant to Disposal of Waste at the Hanford Directed Operations of the H.E.C.

1953 Newcomb, R.C. and Strand, J.R.; U.S. Geol. Survey, USGS-W-P-8, Geology and Ground-water Characteristics of the Hanford Reservation of the A.E.C., Washington.

1959 Brown, D.J.; Hanford Atomic Products Operation, Subsurface Geology of the Hanford Separation Areas.

1972 Newcomb, R.C.; Strand, J.R.; and Frank, F.J.; U.S. Geol. Survey Professional Paper 717, Geology and Groundwater

Characteristics of the Hanford Reservation of the U.S. Atomic Energy Commission, Washington.

1978b Fecht, K.R.; Rockwell Hanford Operations RHO-BWI-LD-5, Geology of the Gable Mountain-Gable Butte Area.

1979 Myers, C.W. and Price, S.M., et al.; Rockwell Hanford Operations RHO-BWI-ST-4, Geologic Studies of the Columbia PlateauA Status Report.

1982 Moore, B.A.; Rockwell Hanford Operations RHO-SA-239, Geophysical Investigations of the Gable Mountain Pond-West Lake Area, Hanford Site, South-Central Washington.

1984 Last, G.V. and Fecht, K.R.; Rockwell Hanford Operations, Groundwater Geology of the Aquifer Intercommunication Study Area, Hanford Site, South-Central Washington.

-HYDROLOGY-

1976 Ledgerwood, R.K. and Deju, R.A.; Atlantic Richfield Hanford Co. Hydrology of the Uppermost Confined Aquifers underlying the Hanford Reservation.

1979 Gephart, R.E. et al.; Rockwell Hanford Operations RHO-BWI-ST-5 Hydraulic Studies within the Columbia Plateau, Washington: An Integration of Current Knowledge.

1981 Graham, M.J. et al.; Rockwell Hanford Operations RHO-ST-42 Hydrology of the Separations Area.

1982 Strait, S.R. and Moore, B.A.; Rockwell Hanford Operations RHO-ST-38 Geohydrology of the Rattlesnake Ridge Interbed in the Gable Pond Area. 


\section{TABLE III}

\section{GROUNDWATER MODELING STUDIES}

1971 Cearlock, D.S.; Pacific Northwest Laboratories BNWL-SA-386 A Systems Approach to management of the Hanford Groundwater Basin.

1972 Kipp et al.; Pacific Northwest Laboratory BNWL-1703 Variable Thickness Transient Groundwater Flow Model: Theory and Numerical Implementation (updated 1976).

1975 Cearlock, D.B.; Pacific Northwest Laboratories BNWL-1706 Transmissivity Iterative Calculation Routine - Theory and numerical Implementation.

1976 Arnett, R.C. et al.; Atlantic Richfield Hanford Company ARH-ST-140 Conceptual and Mathematical Modeling of the Hanford Groundwater Flow Regime.

1976 Deju, R.A., and A.E. Reisenauer; Atlantic Richfield Hanford Company ARH-1d-148 Evaluation of the Hydrology of the Washington Public Power Supply System and the Fast Flux Test Facility Sites.

1976 Intera Environmental Consultants, prepared for the Atlantic Richfield Hanford Company ARH-C-00017 Hydrologic Model Evaluation at the Hanford Waste Facilities.

1976 Gephart, R.E.; Atlantic Richfield Hanford Company ARH-CD-775 Geohydrologic Study of the West Lake Basin.

1977b Arnett, R.C. et al.,; Atlantic Richfield Hanford Company ARH-SA-292 Hanford Groundwater Scenario Studies.

1981 Hal1, M.D.; Rockwell Hanford Operations RHO-LD-157 Near Field Impact of 216-U-10 (U-Pond) Decommissioning on the Unconfined Aquifer.

1982 Dove, F.H. et al; Battelle Northwest Laboratories Assessment of Effectiveness of Geologic Isolation Systems (AEGIS). 1982 Lu, A.H.; Unpublished informal report, Hydrogeological Unit, Rockwell Hanford Operations. Calibration of a Groundwater Flow Model for the Separations Area.

1983 Wilbur, J.S., M.J. Graham, and A.H. Lu; Rockwell Hanford Operations RHO-RE-SR-83-24P Results of the Separations Area Ground-Water Monitoring Network for 1982.

1984 Mitche11, P.J.; Pacific Northwest Laboratory Interna1 Letter to L.S. Prater, Modeling of Ground-water Flow and Tritium Plume in the Hanford Unconfined Aquifer. 
description of the Separations Area was given in Graham (1981). Brown and Rupert (1950) were the first to report radionuclide contamination in the unconfined aquifer. Intercommunication between the unconfined and confined aquifers was examined by Ledgerwood and Deju (1976), Graham (1984), Strait and Moore (1982), and Last and Fecht (1984). Several groundwater flow models of the unconfined aquifer developed for the Hanford Site are listed in Table III. Intera Environmental Consultants, Inc. (1976) constructed a three-dimensional model. The remaining models utilized simplifying assumptions to characterize a two-dimensional flow regime. The Intera model is not a quantitative analysis because meaningful values of vertical hydraulic conductivity, required for three-dimensional characterization, have not been obtained from well data on the Hanford Site.

The groundwater code most commonly used for application at Hanford is the Variable Thickness Transient Code (VTT) (Kipp et al., 1972). Other groundwater codes utilized include U.S. Geological Survey Trescott code, Illinois State Water Survey Prickett and Lonnquist code, Coupled Fluid, Energy, and Solute Transport (CFEST) code, and a code developed by Intera Environmental Consultants (see Table III). The above codes are solved by the finite difference numerical technique, with the exception of CFEST, which uses the finite element scheme. 
GROUNDWATER FLOW MODELING

Methodology for Model Development

A groundwater model is an abstraction of a real aquifer system which is too complex to treat in actual terms. Simplifying assumptions are necessary to translate the system into mathematical terms. The process of selecting simplifying assumptions is very important since the model constructed is based on them. An example of a common assumption is that flow is horizontal (so that the flow in third dimension is negligible).

Groundwater flow models have proved to be useful tools in waste management for the Hanford Site (see Table III for list of various studies). Computer simulations can aid in forcasting water-level variations in response to changes in liquid waste disposal. For example, a model can be used to estimate the impact of decommissioning waste ponds or increasing liquid waste disposal to the confined and unconfined aquifers underlying the Separations Area. In addition, groundwater flow simulations are used as input to radionuclide transport studies, which predict contaminant flow and concentration.

Modeling of groundwater flow requires a conceptual model, an estimation of required parameters (including simplifying assumptions), a selection of a mathematical model and groundwater flow code, and a model calibration. These tasks are briefly summarized below. A complete site specific description of this study's model development starts in Chapter II. 
The Conceptual Model

Groundwater modeling begins with a conceptual understanding of the physical make-up of the aquifer system. The conceptual model describes the groundwater flow system and its relationship to the geology.

Parameter selection is based on specific assumptions regarding the hydrology and geology as well as measurements. The following geohydrological parameters are used for building the physical framework of the conceptual model: hydraulic conductivity, transmissivity, formation thickness, storage coefficient, recharge/discharge, initial groundwater head surface, and altitude of top and bottom of the aquifer. Values for these parameters were collected from previous studies that included surface and borehole geophysical investigations, aquifer well tests, and geologic well logs (see Table II, Geologic and Hydrologic Studies). The conceptual model developed for this study is presented in Chapter II.

\section{The Numerical Model}

A numerical model first translates the physical characteristics into mathematical terms. Differential equations are transformed into a large set of coupled algebraic equations, which can be solved on a high speed digital computer.

The derivations of the differential equations used in most groundwater applications are based on the conservation of mass and energy principles (Darcy's law). Groundwater flow equations have an infinite number of possible solutions. To make the solutions applicable to the Hanford Site, it is necessary to combine additiona? 
input data that define the aquifer's physical system. These constraints are referred to as the initial conditions and boundary conditions which define or describe the initial head in the aquifer and how the flow interacts with the surroundings. The combination of these initial and boundary conditions with the hydraulic properties of the aquifer produce site specific solutions to the flow equations. The differential equations are solved for the unknown or dependent variable, the hydraulic head. A detailed description of the numerical model developed for this study is found in Appendix $B$.

\section{Model Calibration and Validation}

The calibration process involves the adjustment of model assumptions and geohydrological parameters, so that the model input and output reasonably agree with the constraints imposed by observed field data. In this study, the confined aquifer's hydraulic conductivity, the source term, and the interaquifer transfer coefficient are varied to produce several scenarios.

Validation, done after the model has been calibrated, further demonstrates the model's predictive ability. If the model can not only simulate observed field data in a calibration period, but also reproduce historical events within a certain margin of error, then it is considered validated. The model's predictive ability is of course related to the quantity and quality of available data used to build the model.

Results from a model are only an approximation of the real aquifer system. Deviations in the predicted behavior of the aquifer 
are expected to occur because of the underlying simplifying assumptions that the model is based on. Modeling is an iterative process; calibration is repeated as more data is collected, leading to an improved, better constrained model. The confined aquifer models in this study are considered "preliminary" in the iterative sense just described, because only one year of potentiometric data is available for calibrating the steady state simulations. Calibration of the confined aquifer is presented in Chapter IV.

\section{PROBLEM DEFINITION}

Intercommunication, the hydrologic mixing of two aquifers, has been identified between the unconfined and the confined aquifer systems in the study area (Graham, 1981). Erosional thinning and fractures in the basalt confining bed (that separates the unconfined aquifer and confined aquifer system) allow physical contact of the two aquifer systems in portions of the study area (Last and Fecht, 1984). Erosional windows were 117 ustrated in Figure 5. Since groundwater requires at the very least a small a hydraulic gradient for flow (and mixing) to occur, a head differential between the unconfined aquifer and the confined aquifer must exist, in addition to the erosion, for this vertical leakage to occur. Vertical hydraulic gradients in the Separations Area (interpreted from observed potentials between the unconfined and confined aquifer) create the potential for either upward or downward flow directions, depending on the location within the study area.

The study area and its vicinity have been identified as a 
regional discharge area (Ledgerwood and Deju, 1976; Dove et al., 1982; Graham, 1981). Regional pieziometric data of the uppermost confined and unconfined aquifer systems indicate upward hydraulic gradients, i.e. the head decreases toward the ground surface (Dove et al., 1982).

The potential for substantial vertical flow downward direction only occurs in the vicinity of the two major disposal pond facilities. Infiltration of liquid waste to the aquifer systems from Gable Mountain Pond and B Pond has developed large mounds in the unconfined aquifer's water table, creating a head larger than that of the confined aquifer beneath (Strait and Moore, 1982).

The unconfined aquifer within the Separations Area was first reported to be contaminated by waste disposal by Brown and Rupert (1950). Over the years the liquid discharges have caused an increase in concentration of Tritium, Nitrate, Iodine-129, and total beta levels. Intercommunication between the two aquifers has resulted in higher levels of Tritium and Iodine-129 concentrations in the uppermost confined aquifer in certain localities on the Hanford site (Strait and Moore, 1982).

\section{PURPOSE AND SCOPE}

Leakage between the unconfined and confined aquifers may be an important factor for simulation of groundwater flow beneath the Separations Area. The potential for upward or downward movement in the Separations Area warrants an investigation of the possible role 
of this vertical flux between the unconfined and confined aquifer system.

Previous Hanford computer models (see Table III) have not incorporated this leakage. This is due in part to the lack of knowledge of the spread of contamination to the confined aquifer, until recently (Gephart et al., 1976). Also, leaky simulations require additional data from the uppermost confined aquifers, which was not available until 1982 (Graham, 1984). The type of data required depends on the method chosen to analyze the problem. There are two basic methods:

1. Full three-dimensional model - This is the ideal approach to the problem. It has the capabilities of modeling vertical flow patterns directly. The additional data requirements include the definition of vertical hydraulic conductivity, which have not been quantified for the uppermost aquifers on the Hanford site. These values can be determined by conducting appropriate multiple pump testing (Intera Environmental Consultants, 1976).

2. Pseudo three-dimensional model (Bredehoeft and Pinder, 1970) - An alternative approach is to examine this vertical leakage by coupling the two-dimensional systems with a leakage term. Vertical hydraulic conductivity values of the aquifers are not necessary for this scheme since the vertical flow through the aquifer is not modeled, just the vertical coupling. In this approach, the additional data requirements include the effective hydraulic conductivity (vertical hydraulic conductivity of the confining layer), thickness, and the head differential between the two 
aquifers. This study utilizes the pseudo three-dimensional approach in a preliminary attempt to incorporate leakage into a computer simulation of the confined aquifer. Several conceptual models were formulated to characterize a range of plausible hydrogeologic conditions. Sensitivity analyses were conducted by varying each condition separately in a computer simulation, while holding the remaining variable's values constant.

The purpose of this study is to gain insight into the relationship and sensitivities between leakage and selected input parameters (i.e., hydraulic conductivity, boundary conditions, source term, and interaquifer transfer coefficient). In this way, groundwater modeling aids in the conceptualization process and provides a foundation for future studies. Modeling results can guide data gathering efforts by ranking the uncertainty and importance of needed data, and where it should be collected. A complete quantification of the leakage requires a substantial amount of information about the confined aquifer, the aquitard, and the unconfined aquifer that does not exist at this time.

\section{CODE AND EQUIPMENT}

Groundwater flow codes are computer programs. These codes solve differential equations that attempt to describe the aquifer system.

A set of computer codes known as the Variable Thickness Transient (VTT) groundwater code (Kipp, et al., 1972) was used for the flow simulations of this study. This set of codes was developed 
through many years of groundwater modeling experience at Battelle Pacific Northwest Laboratory (PNL). The VTT code uses the finite difference technique to simulate two-dimensional saturated groundwater flow. The codes are written in a variation of the FORTRAN IV-PLUS language. The VTT code was run on a Digital Equipment Corporation PDP 11/70 Minicomputer at PNL. 


\section{CHAPTER II}

\section{CONCEPTUAL MODEL}

This section describes the groundwater flow system and its relationship to the geology. Parameter selection is based on specific assumptions regarding the hydrology and geology as well as measurements. The following geohydrological parameters are used for building the physical framework of the conceptual model: hydraulic conductivity, transmissivity, formation thickness, storage coefficient, recharge/discharge, initial groundwater head surface, and altitude of top and bottom of the aquifer. Values for these parameters were collected from previous studies that included surface and borehole geophysical investigations, aquifer well tests, and geologic well logs.

\section{HYOROGEOLOGICAL PROPERTIES}

The capacity of an aquifer to store and transmit water is principally influenced by three parameters: aquifer thickness, hydraulic conductivity, and storage coefficient. In this section these properties will be described and compiled for the confined aquifer from the review of published and unpublished data.

Data is acquired, to define the hydrogeological properties listed above, from information derived from boreholes (wells) or from pump testing of boreholes. Data shown on Figure 7 were obtained 


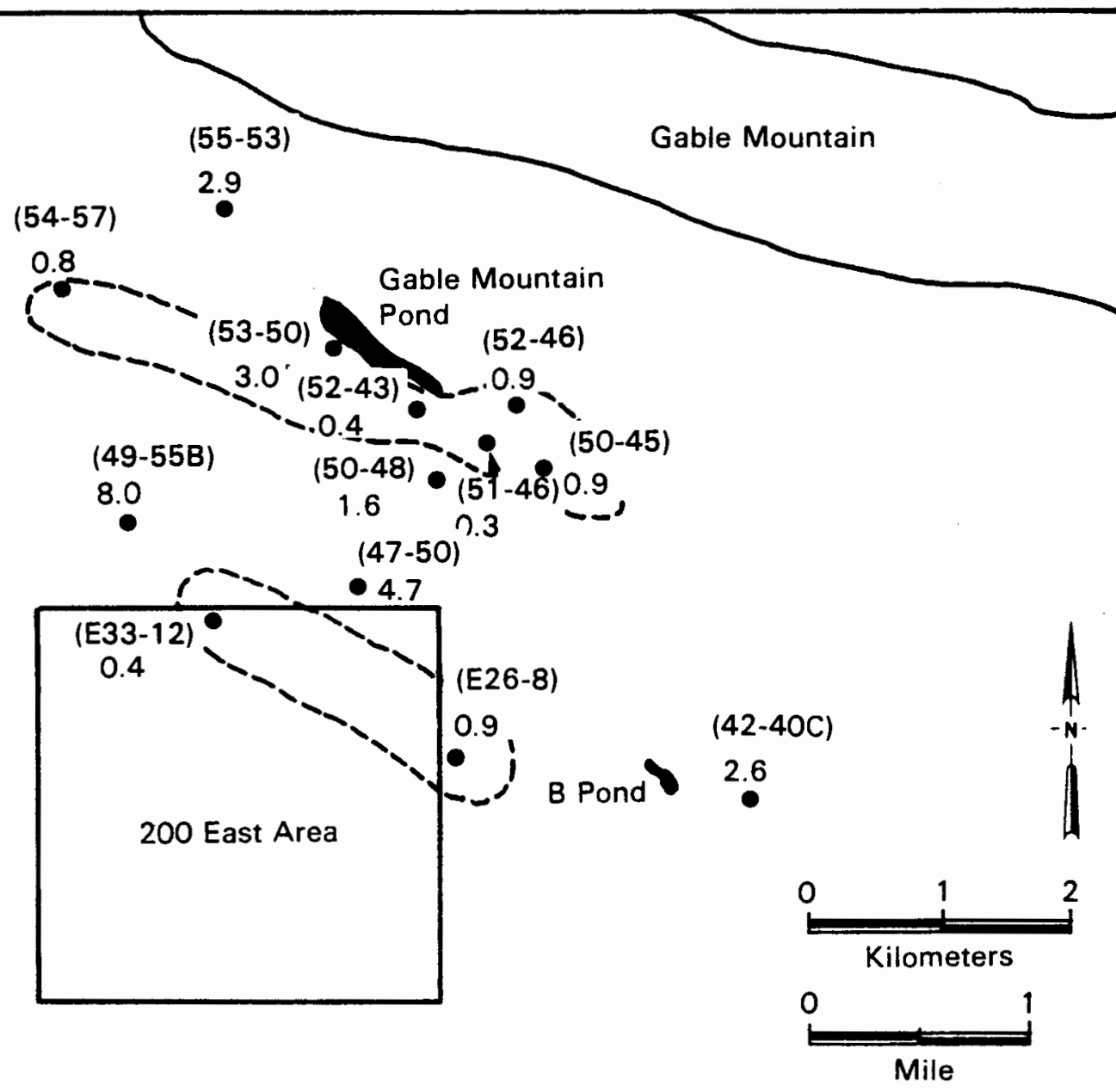

- (BOREHOLE NUMBEP)

Hydraulic Conductivity Values in $\mathrm{m} / \mathrm{d}$ Areas of Relatively Low Hydraulic $\because$ Conductivity (dashed where inferred)

Figure 7. Hydraulic conductivity of the confined aquifer. 
from 13 boreholes for hydraulic conductivity and storativity values (Graham, 1984). Confined aquifer thickness values were derived from 24 boreholes shown in Figure 8 .

Values of head were taken the same 13 boreholes that defined hydraulic conductivity and storativity values (see Figure 7). Collection of monthly head readings was initiated in 1982 (Last and Fecht, 1984).

\section{Aquifer and Confining Layer Thicknesses}

The Elephant Mountain Member, which confines the Rattlesnake Ridge aquifer throughout most of the study area, consists of two basalt flows, the lower Elephant Mountain I, and the upper Elephant Mountain II (see cross-section on Figure 5). Last and Fecht (1984) have described the geology of these flows. The thickness of the Elephant Mountain I flow ranges from 0 to 35 meters and averages 11 meters within the study area. This flow thins out to about 6 meters over Gable Mountain, and thins to zero where it is fully eroded. The upper Elephant Mountain II flow has an average thickness of 8 meters, but is present only in the southeastern and northern portions of the study area.

The uppermost confined aquifer, the Rattlesnake Ridge aquifer, consists of the flow bottom of the Elephant Mountain Basalt, the flow top of the Pomona Basalt, and the Rattlesnake Interbed (see cross-section on Figure 5). The thickness of this aquifer ranges from 24 to 34 meters in the vicinity of the Separations Area (BWIP staff, 1982). An isopach map of the Rattlesnake Ridge Interbed is shown in Figure 8. 


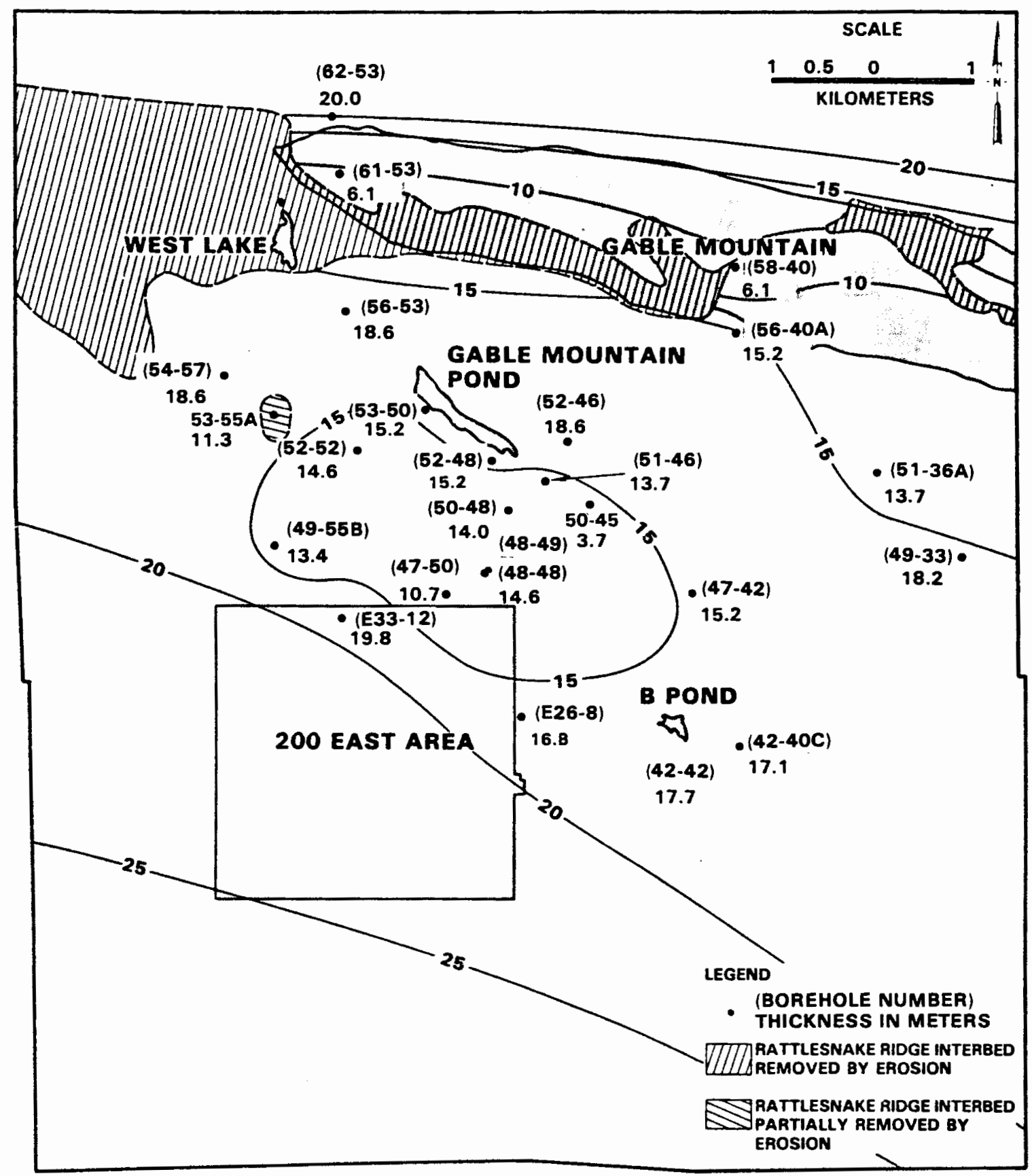

Figure 8. Isopach map of the Rattlesnake Ridge Interbed (modified from Graham, 1984). 
Hydraulic Conductivity/Transmissivity

The hydraulic conductivity $(K)$ is a proportionality coefficient that defines the ability of water to be transmitted through a permeable medium. This parameter describes the rate at which water can move, and is a function of both the medium and the fluid (i.e. density and viscosity) Darcy's Law defines the hydraulic conductivity (K) as:

$$
K=(Q / A) 1 /(d h / d x)
$$

where $K$ is proportional to the discharge $(Q)$, and inversely proportional to both area of flow $(A)$, and gradient of the hydraulic head $(\mathrm{dh} / \mathrm{dx})$ (Fetter, 1980). The dimensions of $K$ are length/time.

The transmissivity $(T)$ of an aquifer is a function of both the hydraulic conductivity and the thickness of the aquifer (b):

$$
T=K b
$$

This property is more useful in quantitatively describing the transmittance of water through an aquifer. The dimensions of $T$ are length squared/time.

Several different tests were used to obtain hydraulic conductivity and transmissivity values at the Hanford Site. The most common was the aquifer pump test. Most of the pump test data were analyzed with the Theis (Theis, 1935) or the Cooper-Jacob (Cooper and Jacob, 1946) method. Values for hydraulic conductivity are listed in Table IV below. 
TABLE IV

RANGES OF HYDRAULIC CONDUCTIVITY IN THE STUDY AREA (unconfined aquifer data from Graham, 1981)

INTERVAL TESTED

HYDRAULIC CONDUCTIVITY

$$
\mathrm{m} / \text { day } \quad \mathrm{ft} / \mathrm{day}
$$

UNCONFINED AQUIFER

Hanford Formation

600 to $3000 \quad 2000$ to 10000

Middle Ringold

3 to 70

9 to 230

Lower Ringold

1 to 3.6

3 to 12

(confined aquifer data from Deju and Fecht (1979); Summers and Weber (1978))

CONFINING LAYER

Elephant Mountain Member .001 to $.01 \quad .01$ to .1 CONFINED AQUIFER

Rattlesnake Ridge Interbed .01 to $1 \quad .1$ to 10

Under the Separations Area, the hydraulic conductivity of the unconfined aquifer ranges from 1-3000 meters/day (Graham et al., 1981). The large range is due to the differences in conductivity of the two formations representing the aquifer. The Hanford Formation consists of loose, unconsolidated sands and gravels of very high conductivity, whereas the lacustrine Ringold Formation consists of relatively compact finer grained material with low conductivity.

The Elephant Mountain Member has very low conductivity, characteristic of the dense interior portion of the basalt flow. The interflow zone, which is located in the upper portion of the member, has much higher conductivity (approximately an order of magnitude) but is missing throughout most of the study site. Few tests were 
conducted to obtain hydraulic conductivity data for this member. This study used the range of hydraulic conductivity data given for the Saddle Mountain Formation, the uppermost formation of the Columbia River Basalt Group (Summers and Weber, 1978; and Deju and Fecht, 1979) (Table IV). Values of hydraulic conductivity (which are mostly related to vertical fracturing) are reported to range between .001 to .01 meter/day. BWIP staff (1982) estimated much smaller values which range from $10^{-6}$ to $10^{-8}$ meter/day, assuming this member has similar characteristics to other Columbia River Basalts.

The varying lithology of the Rattlesnake Ridge aquifer produces a rather large range of conductivity. Hydraulic conductivities are reported to range between .01 and 1 meter/day (Deju and Fecht 1979; and Summers and Weber 1978) and also reported to range from .01 to 10 meter/day (BWIP staff, 1982). Graham (1984), summarized recent aquifer test results (transmissivities). Hydraulic conductivity values were computed for this study by dividing these transmissivity values by aquifer thickness (thickness values from Graham, 1984). The conductivity values ranged from .3 meter/day to 8.0 meter/day (see Figure 7).

\section{Storage Coefficient}

The storage coefficient is defined as the volume of water an aquifer releases from or takes into storage, per unit surface area of the aquifer per unit change in head. Values for the storage coefficient have been computed from the aquifer pump tests as previously described (Graham, 1984). The storage coefficient for 
the unconfined aquifer ranges from .002 to .07 (Deju, 1974 and unpublished data, respectively) and is estimated to be $10^{-4}$ for the confined aquifer (Deju and Fecht, 1979).

\section{RECHARGE/DISCHARGE}

Recharge can be defined as the replenishment of water to the aquifer, while discharge is the withdrawal of water from the aquifer. Recharge to the aquifer system can occur from precipitation, rivers and creeks, disposal waters, irrigation, and by intercommunication between the overlying or underlying aquifers. Components of recharge and discharge for the confined Rattlesnake Ridge aquifer are 11 lustrated in Figure 9.

Soil moisture (lysimeter) studies in the Separations Area have found no appreciable recharge to the groundwater table from precipitation (Gee and Heller, 1985). Precipitation in the Pasco Basin is only 15 to $18 \mathrm{~cm}$. per year, with potential evapotranspiration greatly exceeding this (Stone et al., 1972). Recharge to the unconfined groundwater system does occur in the highlands bordering the basin (see Figure 3) where there is increased precipitation from orographic effects. Recharge in the Pasco Basin also occurs from the Columbia and Yakima Rivers and a few ephemeral creeks that drain the area. Irrigation of Upper Cold Creek Valley, located outside the Hanford Site, contributes a considerable amount of recharge. A small amount of recharge may occur from irrigation still allowed to the west and north/northwest of the Hanford Site. The main source of recharge to the unconfined aquifer in the study 


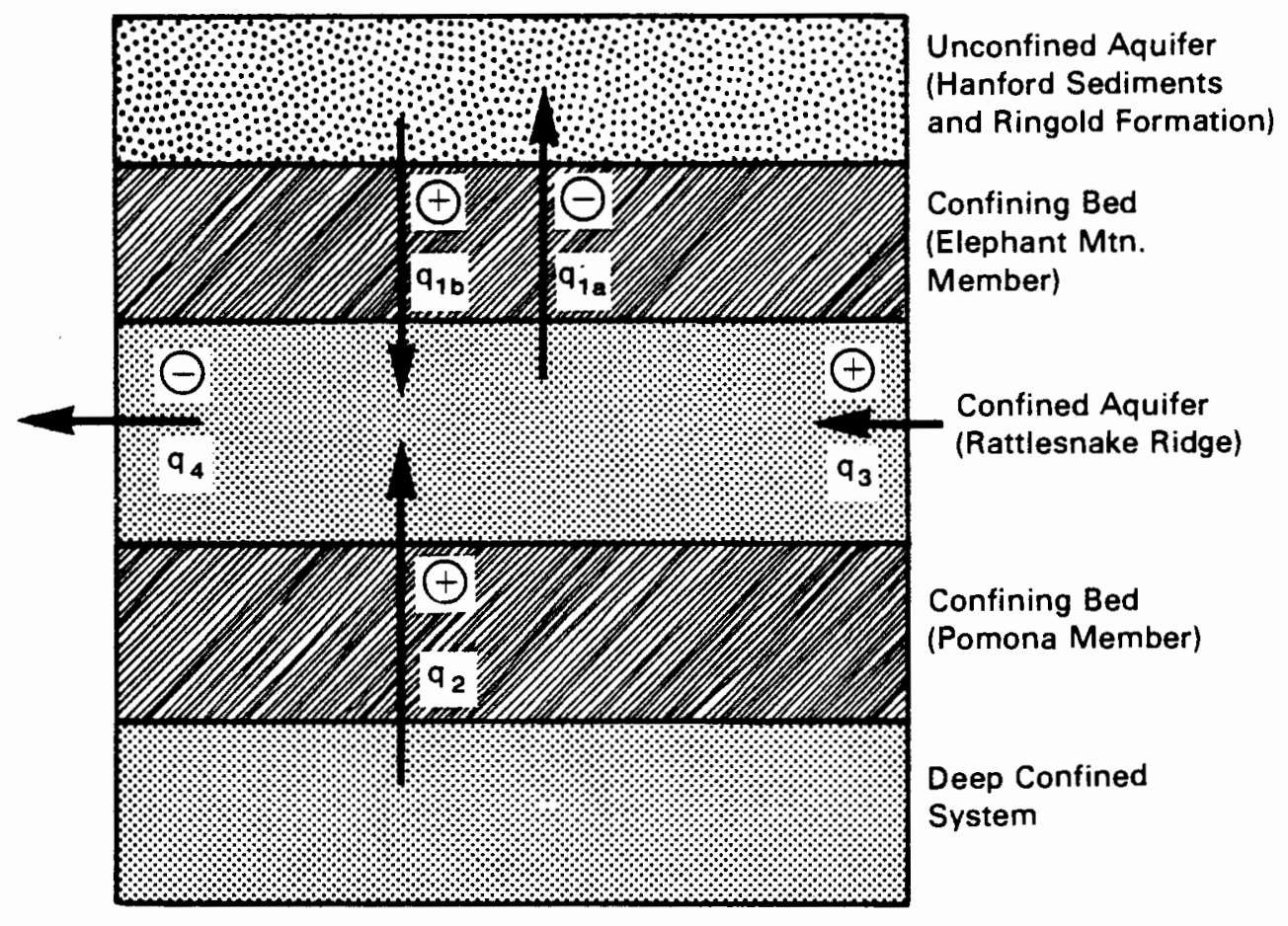

$\mathrm{q}=$ Flux $\fallingdotseq$ Discharge $\oplus$ Recharge

$q_{1}=$ Leakage between unconfined/confined aquifers

$q_{1 a}=$ Discharge when confined aquifer's potential > unconfined aquifer's potential

$\mathrm{q}_{1 \mathrm{~b}}=$ Recharge when unconfined aquifer's potential > confined aquifer's potential

$\mathrm{q}_{2}=$ Leakage between confined aquifer and deeper confined system. Always in upward direction

$q_{3}=$ Recharge from outcropping in highlands (e.g. Gable Mountain)

$\mathrm{q}_{\mathbf{4}}=$ Discharge to Columbia River 
area comes from the infiltration of waste waters from disposal sites in the 200 West and 200 East areas (Graham, 1984). The two major disposal ponds (Gable Mountain Pond and B pond) are shown in Figure 1. This artificial recharge may be ten times the amount of natural recharge that the study area receives (Graham, 1981). The unconfined aquifer may also receive recharge from the underlying basalt aquifers, (see Figure 9 , area $q_{1 a}$, for example). The quantity of this recharge is likely to be larger in areas where the confining dense basalt is highly fractured, is completely eroded, or is small in thickness (Last and Fecht, 1984).

The unconfined aquifer predominately discharges to the Columbia River to the north, east, and southeast of the study site. Discharge can also occur downward to the confined aquifer systems, when its hydraulic head is relatively greater than the confined aquifer (see Figure 9 , area $q_{1 b}$, for example). This situation was documented as possible in the late 1960's and early 1970's, when the water table was at a higher level (Graham, 1984).

Recharge of the uppermost confined Rattlesnake Ridge aquifer mainly occurs in the highlands that bound the basin to the west, north, and northeast where the interflow zones structurally intersect the land surface (Graham, 1984). Recharge from Gable Mountain may occur, but more data are needed to define a flux into the confined aquifer (see Figure 9, area $q_{3}$, for example). Upward leakage from deeper confined aquifers also contribute to the recharge of the Rattlesnake Ridge Aquifer (see Figure 9, area $q_{2}$, for example). 
The Rattlesnake Ridge aquifer has two discharge components, a horizontal one that leads to discharge at the Columbia River (see Figure 9, area $q_{4}$, for example), and a vertical one, which can produce upward leakage to the unconfined aquifer when the hydraulic gradient is in the upward direction (see Figure 9, area $q_{1 a}$, for example). Upward hydraulic gradients were interpreted from potentiometric data from the unconfined and confined aquifer system (Graham, 1984 and Dove et al., 1982).

\section{FLOW SYSTEM GEOMETRY}

\section{Groundwater Movement}

Flow direction is governed by hydraulic head with groundwater moving from areas of higher to lower hydraulic head. Aquifer recharge and discharge areas influence the gradient.

Groundwater basins may have various areal systems. Each system can be thought of as a component of the flow, which may have unique recharge and discharge areas and be influenced by separate groundwater boundaries. These systems are described in this study as regional (Columbia Basin), intermediate (Pasco Basin and Hanford Site), and local flow systems (Separations Area and study site). Figures 6 and 10 show the potential surface of the confined system interpreted on a regional, intermediate and local scale.

Confined Aquifer. Intermediate and regional flow systems play an important role in characterizing the confined aquifer boundaries and flow directions. The combination of a complex local hydrogeologic system and a limited local data base makes detailed 
definition on the local scale a difficult task. The groundwater flow geometry of the study area must be inferred from regional trends.

The study site is located in a discharge area for the uppermost confined aquifer system as suggested by the converging equipotential lines of the Saddle Mountain/Wanapum Basalt Aquifer System (regional and intermediate systems) of Figure 10. Pieziometric readings of the Mabton Interbed, the Rattlesnake Ridge Interbed, (see Figures 2 and 5 for stratigraphic location) and the watertable indicate an increase of head with depth (Figure 11). A flow component of the confined aquifer also discharges into the Columbia River, southeast of the study area.

On a local scale, the converging nature of the flow creates a complex flow system that is difficult to delineate. Within the north-west quadrant of the study area, where most of the confined aquifer wells are located, the flow direction appears to be roughly northeast to west/northwest (see Figure 6). Since little well data for the Rattlesnake Ridge Aquifer exists northeast of the study site, the extent of this flow vector is unknown and may be just a localized gradient. Three possibilities that would lead to this westwardly flow configuration are:

1) Recharge from Highlands to the Northeast of the Study Site. This hypothesis requires the Rattlesnake Ridge aquifer's westwardly flow vector (of the study site) be extensive, i.e. coincident with the regional confined system's flow originating in northeastern Washington (see Figure 10). There is no evidence that this extensive 


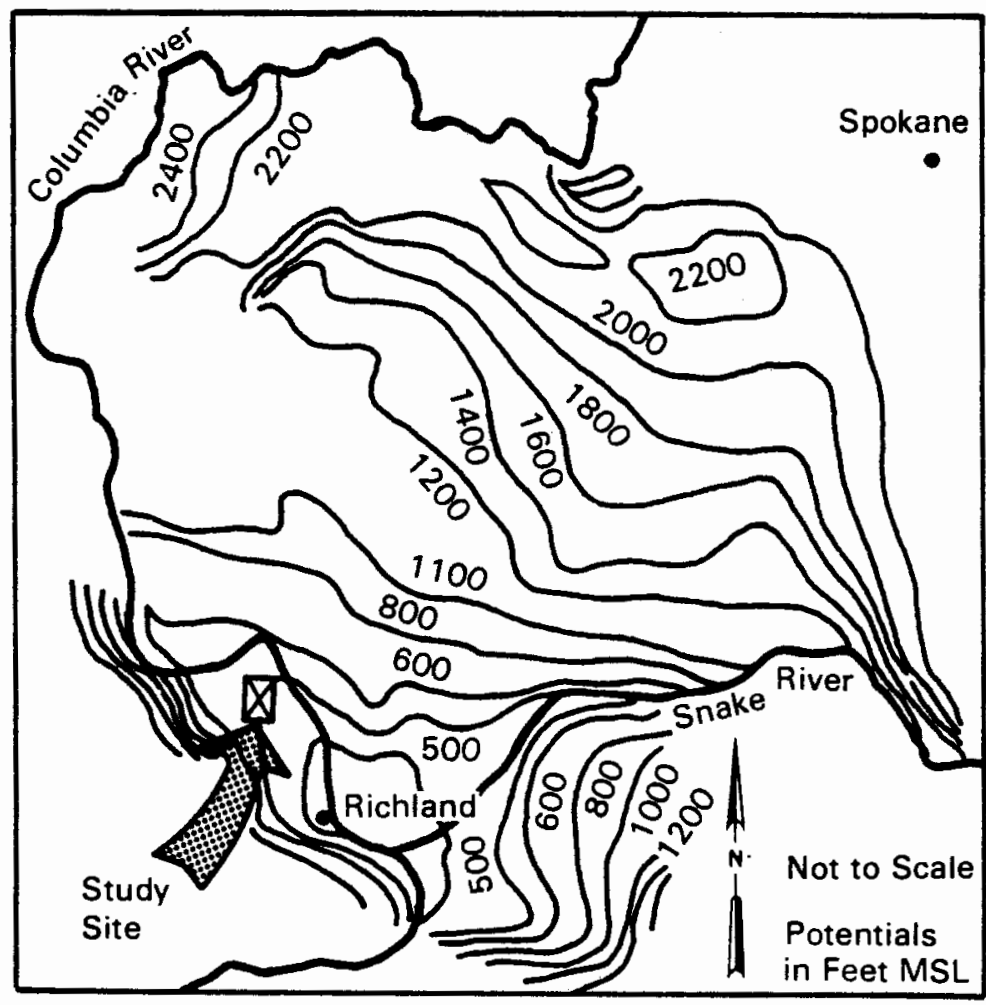

Interpreted Potential

Surface of

Saddle Mountain/Wanapum

Basait Aquifer System

$\bigotimes$ Study Site

Regional

Flow System

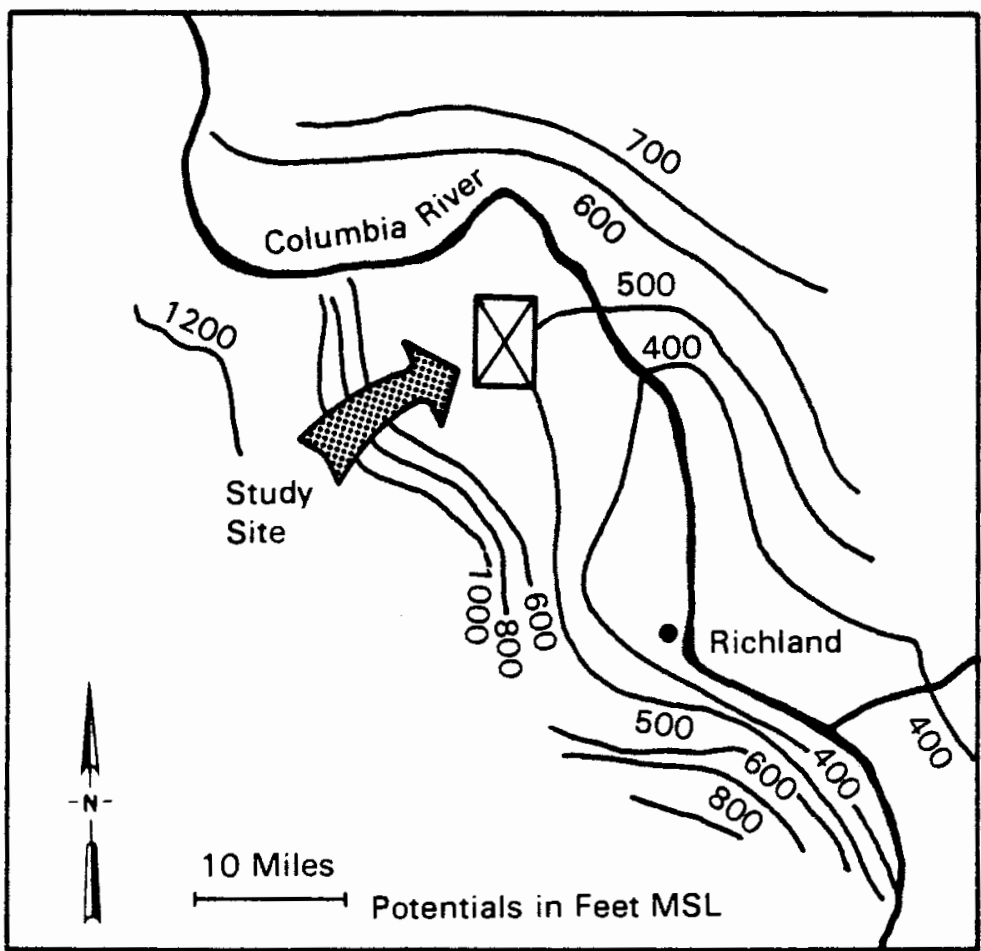

Interpreted Potential

Surface of

Saddle Mountain Basalt

Aquifer System

$\bigotimes$ Study Site

Intermediate

Flow System

Figure 10. Potentiometric surfaces for Regional and Intermediate Flow Systems (modified from Dove et al., 1982). 


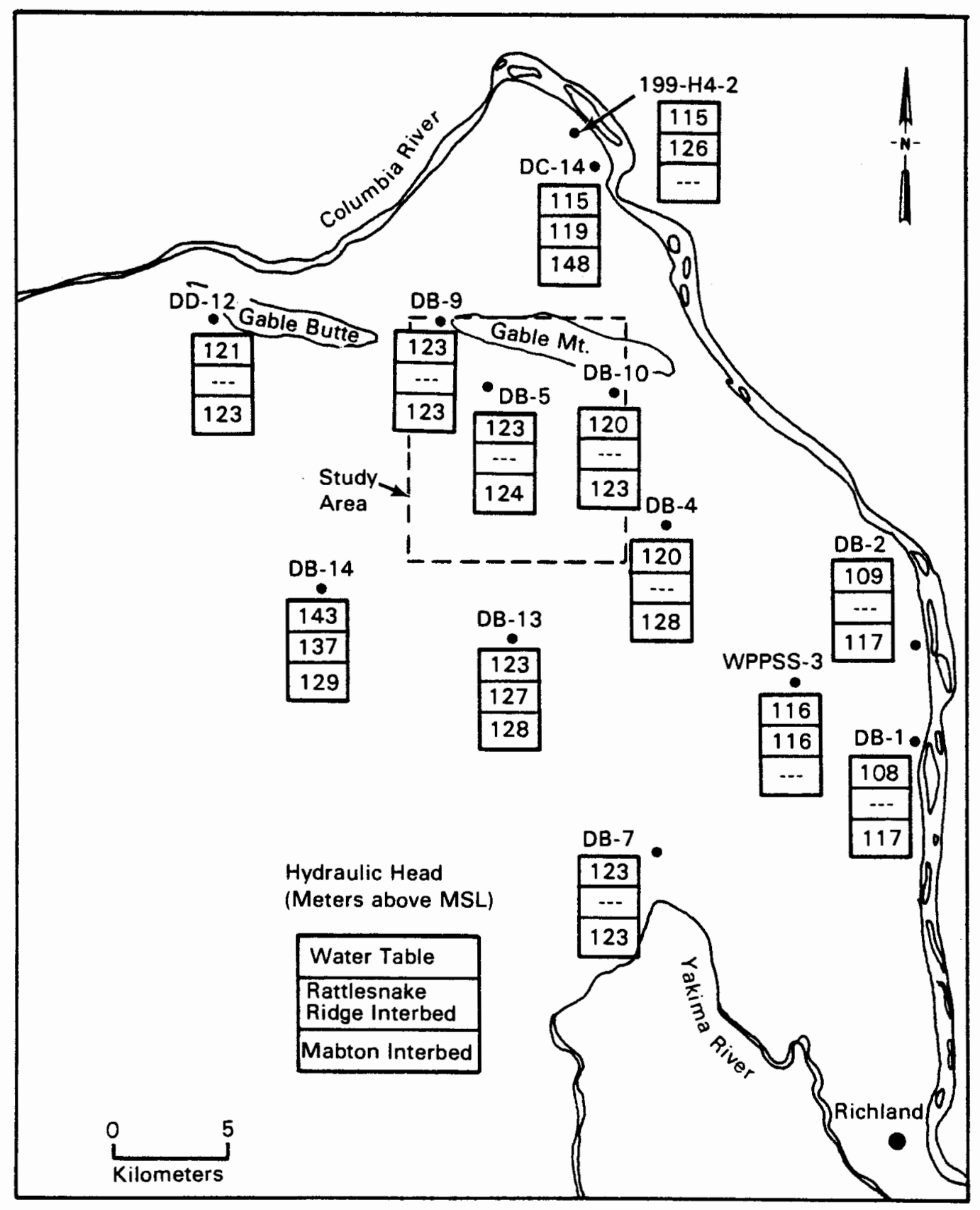

Figure 11. Observed head potentials between the Mabton and Rattlesnake Ridge Interbeds and the unconfined aquifer (modified from Dove et al., 1982). 
relationship exists, and furthermore, Hanford well data suggests that this regional flow vector changes direction on the Hanford site to a southeasterly direction (see Figure 10).

Strait and Moore (1982) suggest that recharge from Gable Mountain could possibly produce the westward flow lines, but give no direct evidence for this occurance.

2) Recharge (leakage) from Overlying Unconfined Aquifer. Recharge from downward leakage of the unconfined aquifer in the vicinity of Gable Mountain Pond could create a mounding of elevated head in the confined aquifer. This hypothesis suggests that the westward flow component may be a local expression of the west flanks of this mound. This westward flow component, however, is found just northeast of Gable Mountain Pond, suggesting that the pond's leakage cannot be the sole contributing factor unless the recharge to the confined aquifer is translated off to the east.

3) Recharge (Leakage) from Underlying Confined Aquifers. The observed westward flow vector could be a flank of a mound possibly created from a deep source. The complex geology (i.e., folding) found in the Gable Mountain Pond area (see Figure 4) could cause fracturing and faulting of the basalt layer, providing avenues for vertical leakage from deeper aquifers.

Unconfined aquifer. The groundwater flow direction of the unconfined aquifer is predominately west to east in the study area (Graham, 1981) (see Appendix A, Figure A.1.). This flow is interrupted by the recharge of waste waters perculating down from disposal ponds. This recharge produces groundwater mounds that form 
steep radial gradients away from the disposal ponds. Two mounds predominately alter the natural flow regime in the study site. They occur in the vicinity of $B$ Pond and the eastern portion of Gable Mountain Pond. In these areas, the unconfined hydraulic potential may be higher than the underlying basalt confined potential, resulting in a downward gradient.

\section{Hydraulic Conductivity}

Values of horizontal hydraulic conductivity are shown in Figure 7. Two areas were found to have relatively lower values of hydraulic conductivity. It is interesting to note that these areas correspond to the trend of the two folds shown in Figure 4. Perhaps the folding has decreased the horizontal conductivity of the Rattlesnake Ridge Aquifer by producing vertical fractures that were later filled with secondary mineralization.

The possibilities listed above are tested in a variety of modeled conditions, to be described in the "model strategy" and "model calibration" sections.

\section{Hydraulic Boundaries}

The uppermost confined aquifer, the Rattlesnake Ridge aquifer, is bounded to the north by the Umtanum/Gable Mountain anticline, and to the northwest by scoured paleochannels, consisting of permeable sands and gravels from the Missoula Flood (Hanford Formation) (see cross-sections of Figure 5 for scoured paleochannels). 
The unit may extend laterally outside the Hanford Site (Myers et al., 1979). To the west, south, and east, its natural boundaries are not easily defined due to lack of data. 


\section{CHAPTER III}

\section{MODEL STRATEGIES AND ASSUMPTIONS}

This study utilizes recently obtained head values for the Rattlesnake Ridge aquifer in a preliminary attempt to model the groundwater flow with a computer simulation. Aquifer intercommunication was modeled in a pseudo three-dimensional modeling approach, as previously described. Since the Rattlesnake Ridge aquifer has a limited data base, several scenarios were modeled, testing a variety of plausible conditions that may exist. This study seeks basically to produce models that include the following features:

A. Create a model that contains a vertical hydraulic gradient (head differential) that allows upward leakage throughout most of the site (with the exception of areas in the vicinity of the two major waste disposal ponds). Upward leakage requires the heads of the confined aquifer to be greater than the unconfined heads.

B. Create a model that possesses a downward hydraulic gradient in the vicinity of Gable Mountain Pond and B Pond, where recharge to the unconfined aquifer from disposal practices produces a net downward leakage.

C. Create a model that mimics the interpreted flow configuration, extrapolated from observed data (see Figure 6). This data suggests that a westward flow component exists in the center of 
the study site. The data are mostly concentrated in a small region of the site, hence the extent of this flow component is unknown. Hanford site readings indicate the predominant flow direction of the confined aquifer is to the southwest, suggesting that this westward component may be local in extent (compare Figures 6 and 10). In addition to the three features listed above, this study seeks to produce models that contain head differentials shown in Figure 12. Differentials were estimated for this study by measuring the difference between potentiometric readings in the confined and unconfined aquifers (from closely spaced wells) during 1981-83.

\section{SENSITIVITY ANALYSIS}

The features outlined above can be simulated in an infinite number of ways. Since aquifer properties are not well constrained, a range of plausible values are assigned to each model component (defined here as a combination of parameters or properties) which is allowed to vary in the study. In order to reduce the number of possibilities for a more manageable analysis, this study limited the number of varying components to four. They are:

1. Source term

2. Interaquifer transfer coefficient

3. Hydraulic conductivity

4. Boundary conditions

Furthermore, not only is the number of variables limited but the range of values assigned to each one and its spatial extent must also be constrained for this study. Various sets of plausible vaiues 


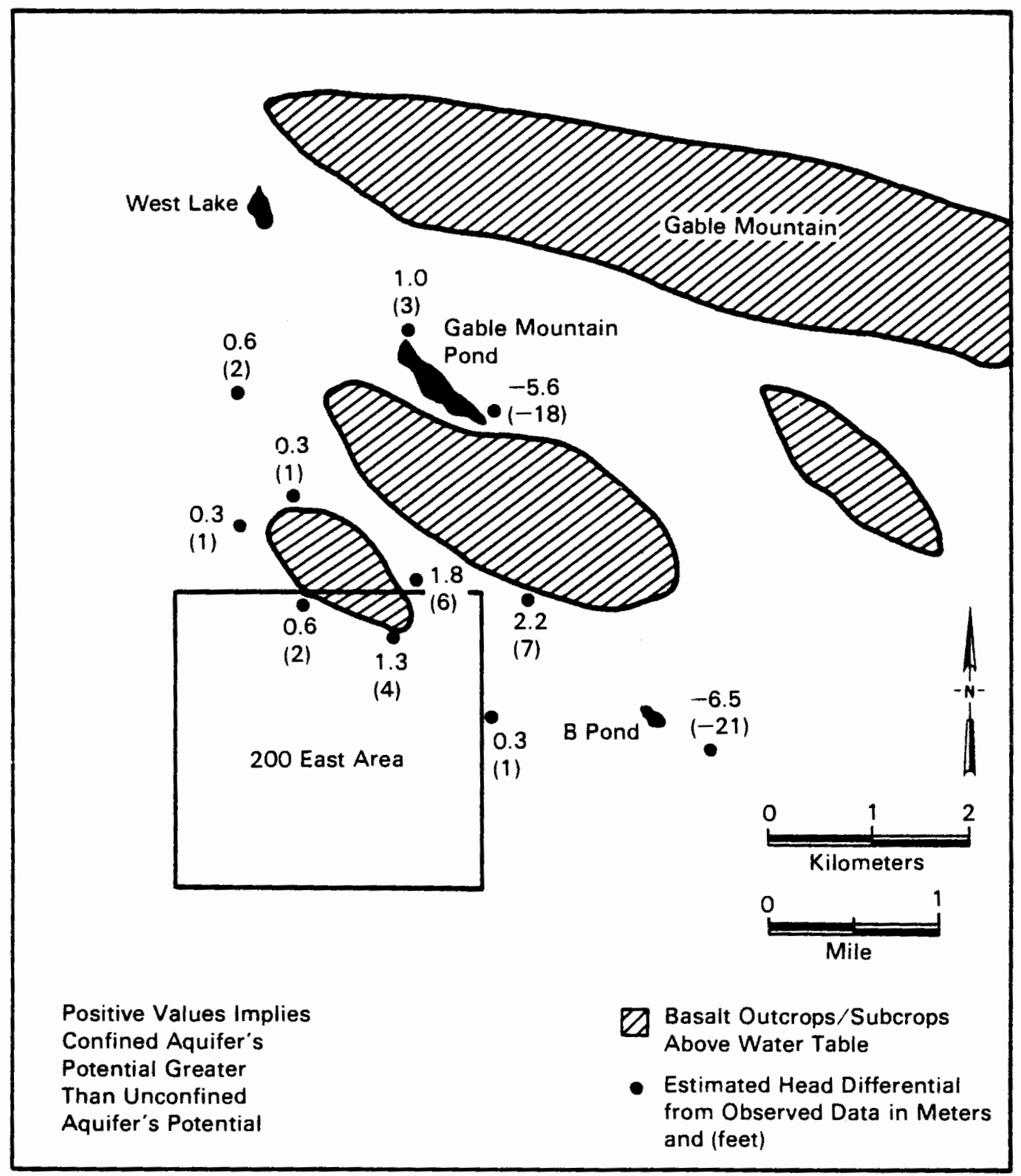

Figure 12. Estimated head differentials between the confined and unconfined aquifer, 1982-82 
characterizing each model component are described in the calibration section. Each set is referred to in this study as a "condition". Model components and their associated conditions (designated as $A-W$ ) are outlined in Table $v$. The number of conditions chosen for each component is related to the size of the range of values deemed plausible. Table $V$ shows for example, the source term having eight conditions (Conditions $A-K$ ) to characterize its distribution of values, while the hydraulic conductivity and the boundary conditions have only three conditions each (Conditions $R-T$ and $U-W$, respectively). This is because relatively less is known about the source term than the other properties. Therefore, its influence on the model needs to be tested. A total of twenty three conditions are defined for the distribution of values of the four variable model components.

A brief description of each of the four components is included in the calibration section (Chapter IV). In addition, magnitudes are assigned to the components along with their underlying assumptions and limitations (which aids in assessing the credibility of these interpretations).

One of the objectives of constructing these models is to gain insight into the relationships between the aquifer system's properties. A sensitivity analysis was performed to examine this. It consisted of varying one model component while holding the remaining aquifer's property values constant. The model's sensitivity to this change is reflected in the solution. For example, if small changes in a given component induces large changes 


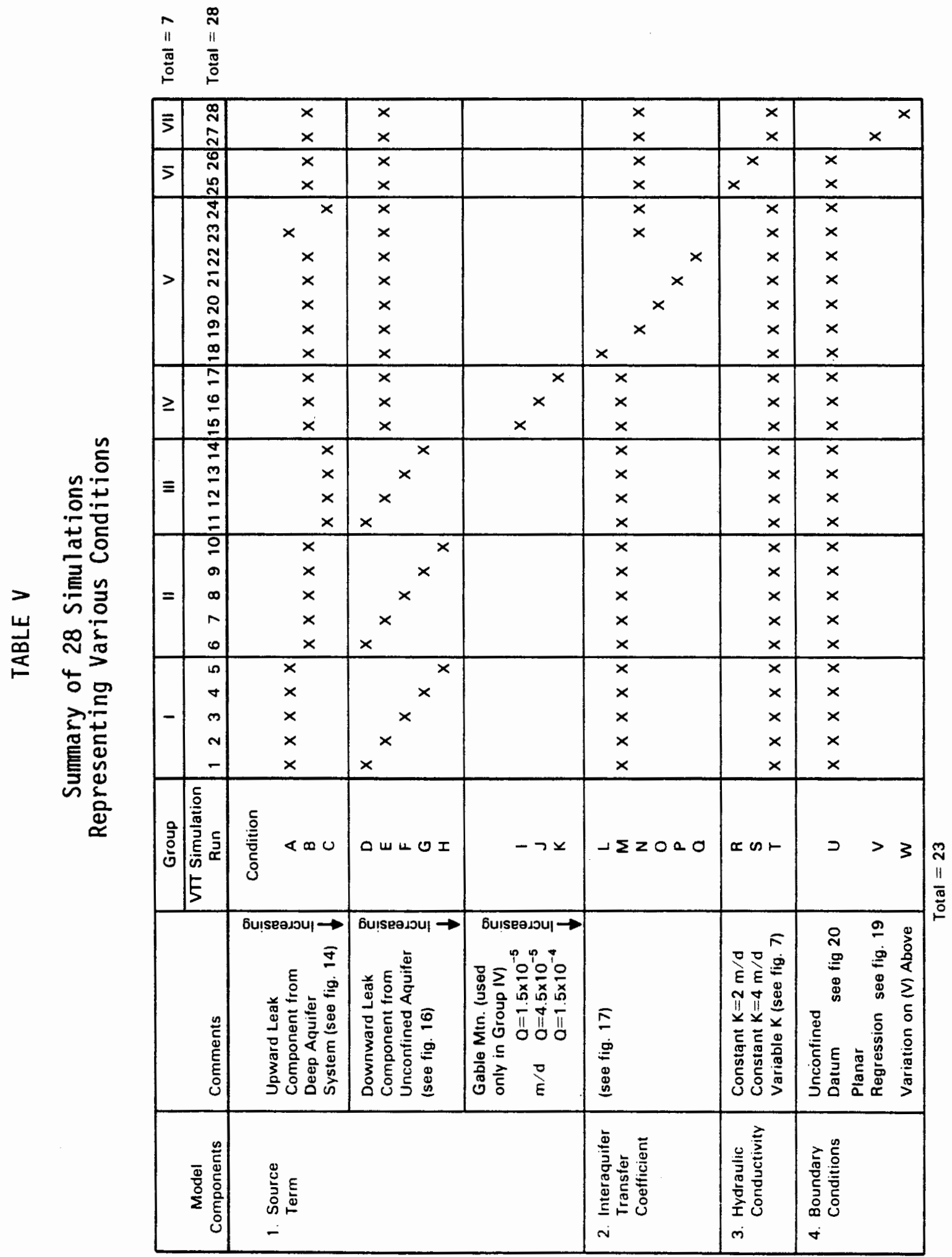


in the model's solution, the modeled system is described as being sensitive to the given component. The sensitivity of the model to the variance of a model component is also dependent on the values assigned to the other aquifer properties. As a consequence this produces a large number of possible scenarios to test. Therefore, as done previously, the possibilities were reduced to a more reasonable number (and still tested the model adequately). Table $V$ illustrates the various combinations of conditions describing the four variable model components that make up twenty eight simulation runs chosen in the analysis. Each run was solved for the head distribution in the confined aquifer. Hydraulic head differentials were then computed at each nodal location (see Appendix B) as the difference between the head of the confined aquifer and the unconfined aquifer. Unconfined potential's were obtained from a separate computer model described in Appendix $A$.

The physical plausibility of the differential values of each simulation was evaluated by calculating their corresponding residual error, computed in this study as the standard deviation of the difference between the calculated differentials and the differential values as interpreted from observed data. Furthermore, the plausibility of these simulations is judged by how reasonable each simulation is, e.g., how well each fits into the regional conceptual model picture.

These twenty eight simulation runs were broken into seven groups for easier evaluation (Table V). Groups I through VI were constructed with confined boundary condition values estimated by 
extrapolating from the unconfined potential surface. By prescribing boundary conditions extrapolated from a planar regression of observed data points, Group VII examined the model's sensitivity to this type estimate of the boundary values. Eleven conditions of varying source term were evaluated in Groups I through IV. The interaquifer transfer coefficient was varied in six conditions of Group V. The hydraulic conductivity distribution, representing two conditions, is evaluated in Group VI.

The range of values defined for each mode component and their corresponding spatial extent are further described in the caltbration section.

\section{TIME FRAME}

Disposal of liquid waste to ponds and cribs over the last 30 years has caused fluctuations in both the unconfined and confined aquifer's potentiometric surfaces, as shown in the hydrograph of Figure 13. Hydrographs from the unconfined aquifer indicate that the potentiometric surface remained fairly constant from approximately 1975 to 1981. Potential fluctuations began after 1981, with a larger rate of increase occurring after 1983. A large increase in the rate of disposal discharge occurs after 1979. Hydraulic head measurements for the confined aquifer suggested that the confined system probably was in a relatively steady state period in 1982, when a program for data collection was initiated. Perturbations in the head readings occur the following year.

A groundwater flow model can be run in either a steady state or 
(w) je!puelod

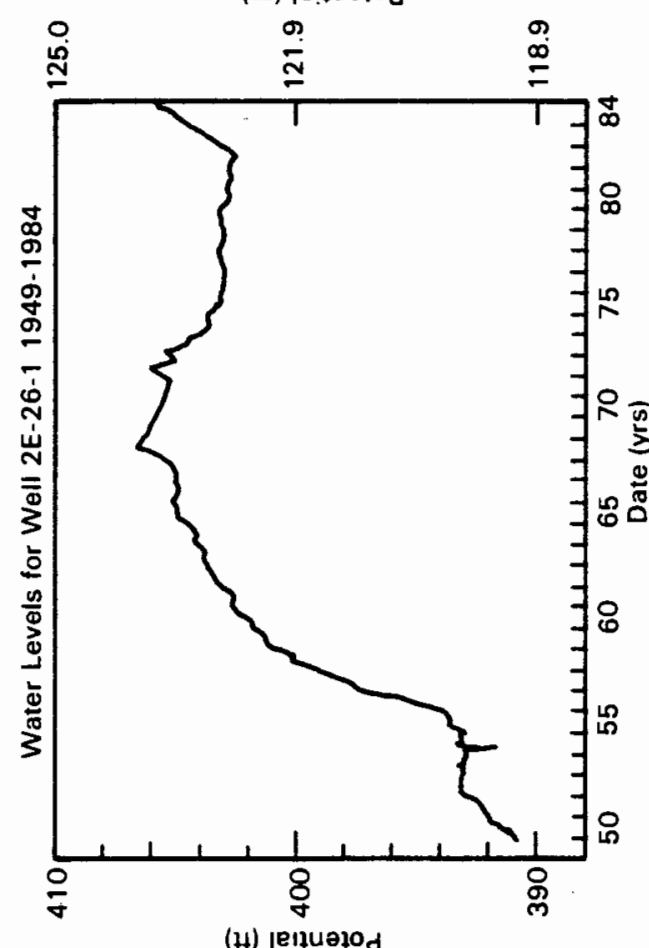

(4) je!luelod

(w) je!nuelod
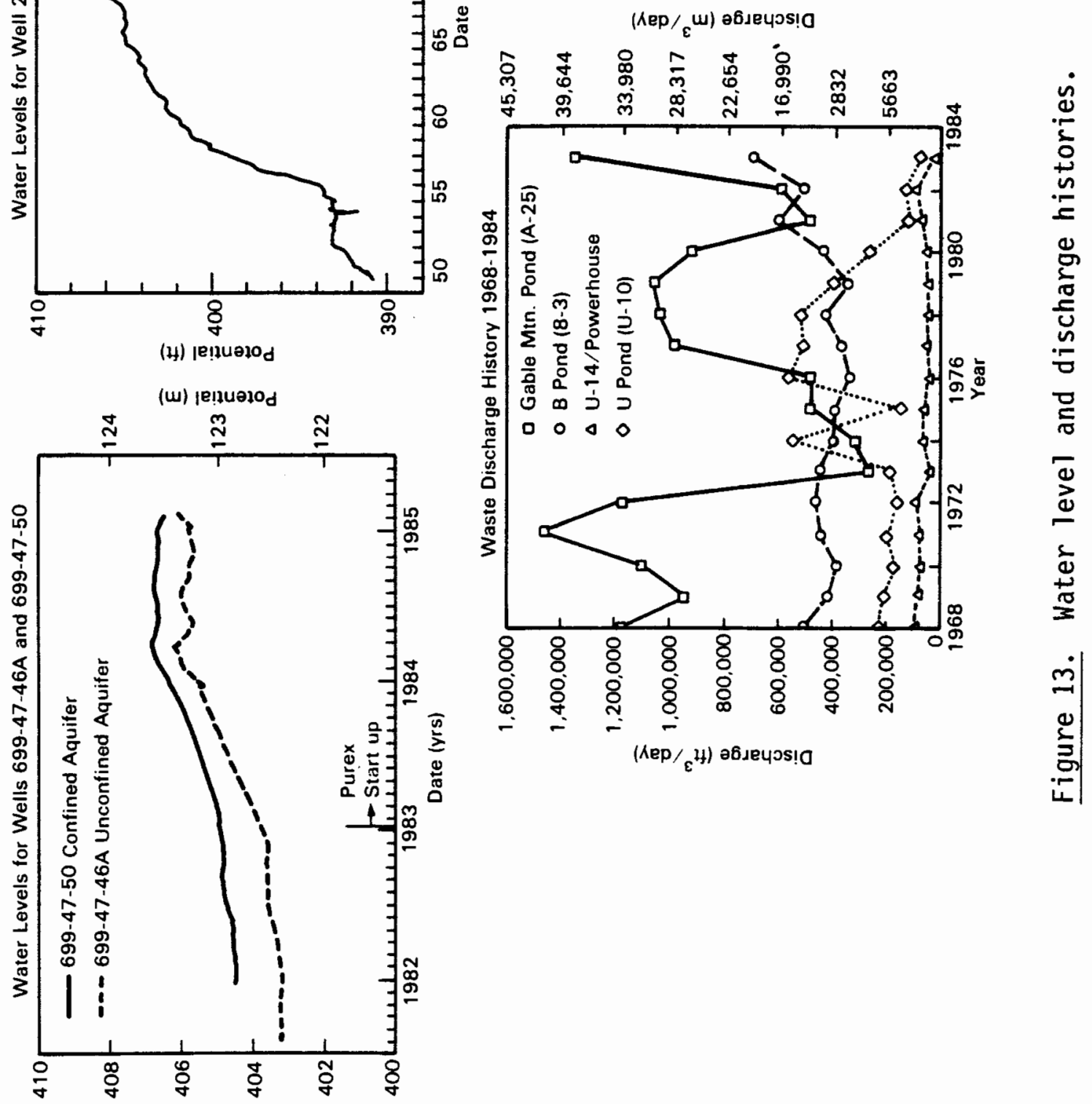

(4) je!lualod 
transient time frame. Steady state conditions imply that the hydraulic heads in the system are independent of time i.e, that the system is in equilibrium, while a transient condition implies disequilibrium. Transient runs require more detailed data for calibration, such as hydraulic heads as a function of time. Most systems are not in an ideal steady state condition, and further, the additional data to construct a transient model is not available. Models are commonly run in steady state if perturbations in head values are minimal, with the time frame chosen to represent the most steady period.

A steady state period in the unconfined and confined aquifer system was chosen for calibration. A time frame that represents the best steady state period was chosen by examining hydrographs of both the unconfined and confined aquifers and disposal rates of liquid waste. A period limited to the last decade was desired for the calibration since there is more confidence in the quality of data collected then. Monitoring of the confined aquifer's potential has only recently been initiated.

The rate of waste disposal discharge increased after approximately 1979. Because of the lagtime in the unconfined aquifer (period of time elapsed for aquifer to respond to stress in system), this increase in flux doesn't show up in the unconfined aquifer's potentials until roughly 1980-1981, with a major increase in 1983 . The confined aquifer's potentials increase after 1983, soon after measurements were initiated. 
The time frame chosen for calibration was 1977 to 1979, when data indicates the best steady state period.

\section{BOUNDARY CONDITIONS FOR THE CONFINED AQUIFER}

Boundary conditions for the confined aquifer were estimated since no natural boundaries (other than the impermeable boundary created by Gable Mountain) occur in the study area. Potential values characterizing the confined aquifer were assigned to boundary nodes and held constant. Two methods were used to derive these potential values since no data exists at the study site's boundary.

The first method estimates potentials at boundary nodes by fitting a planar regression through the 13 observed potential values shown in Figure 6 . These boundaries are characterized in Condition $V$ and $W$, and are simulated in Group VII (Table V). A more detailed description is presented in the calibration section (Chapter IV). This condition would produce a southwestwardly flow and hence characterize recharge from highlands (to the northeast) shown in Figure 10.

Estimation of the potentials at boundary nodes by the second method is more complicated and needs a detailed description of the aquifer system's physics as justification.

The Rattlesnake Ridge and the unconfined aquifer have similar flow patterns within the study area. Evidence of this relationship is shown in many hydrographs of the unconfined and confined aquifers from readings of wells located in the study area. Figure 13 shows, as an example, this relationship in a hydrograph of wells 699-47-50 
(confined aquifer) and 699-47-46A (unconfined aquifer). The head values of the unconfined aquifer increased during 1983, soon after waste disposal increased. The confined aquifer shows the same increase, but with some lagtime (for leakage to occur).

The resemblance in flow patterns (of the two aquifers) is caused by their intercommunication. This relationship is hypothesized to cause the confined aquifer's heads (which is Iarger than the unconfined in most of the study area) to approach values of the unconfined potential. The difference in heads of the two aquifers is related to the degree of intercommunication. For instance, if the two aquifers were completely connected, the head differential would approach zero. Differentials have been estimated for this study by measuring the difference between potentiometric readings of the confined and unconfined aquifers (from closely spaced wells) during 1982-83. The average differential from June 1982 to June 1983 was estimated to be .3 meters in the study area.

If this intercommunication extends out to the study area's boundaries, then we can assume that the confined aquifer mimics the unconfined aquifer in this region. This relationship permits the potentials of the unconfined aquifer along the perimeter of the study area to be used for estimating boundary conditions for the confined aquifer. Potentials of the unconfined aquifer, derived from a model described in Appendix $A$, are a preferred datum for this estimation of boundary conditions, since a large data set (in constrast to the confined aquifer) defines this aquifer. 
Boundary potentials for the confined aquifer were estimated by adding .3 meters (the averaged differential value) to the potentials assigned to the unconfined aquifer along most of the study area's boundary (with exceptions of this assignment occurring along the southwest and northern boundary described below). In this way, the modeled boundary potentials of the unconfined aquifer were used as a datum. These boundary conditions are used in Condition $U$ of Groups I-VI (see Table V). A more detailed description of these runs are included in the calibration section.

This approach requires three assumptions:

1. The difference between the potentials of the unconfined and confined aquifers have remained fairly constant over time.

2. Intercommunication extends out to the study area's boundaries.

3. Error in computing potentials (modeled) for the unconfined aquifer is small.

In the West Lake area, the differential was assigned a value of zero, i.e., the confined aquifer's boundary potentials were estimated to be equal to the unconfined (see differentials of Figure 11). Scouring of the Elephant Mountain Member, confirmed by geophysical evidence (Moore, 1982) has produced a hydraulic interconnection between the confined and unconfined aquifer, which has equilibrated the two aquifer systems (Gephart et al, 1976).

Boundary conditions were also calculated differently in two regions (for both methods described above): one in the southwest corner of the site, and the other in Gable Mountain. Liquid waste 
disposal occurring west of the study area has produced elevated potentials in the unconfined aquifer in the southwest corner of the study site (shown in Figure A.1., Appendix A). Therefore it is possible that the unconfined aquifer's potential is greater than the confined aquifer's potential in this area. A reasonable estimate of the head differential is thus subtracted from the unconfined potential in this region for the estimation of the confined model boundary potentials (Figure 6, southwest corner). The second region is located in the northeast portion of the site, where nodes are assigned as impermeable boundaries to represent "no flow" through Gable Mountain.

Because of the limited data base, estimating the potentials at the (held) boundaries was a preferred strategy for boundary condition values, rather than the conventional implementation of extending boundaries out great distances away from study area. Enlarging this model with all its complexities and uncertainties (based only on thirteen data points) may promote errors, and was thus avoided.

\section{ASSUMPTIONS}

The major assumptions applied in the confined aquifer model include:

1. System's flow is horizontal (two dimension).

2. Porous medium is non-homogeneous, isotropic and is treated as a continuum.

3. Steady state conditions 
Errors are inherent in constructing a model for any physical system. Since all of the uncertainties can not be described, some of the major ones are given:

1. Transmissivity values - a) Rarely do wells fully penetrate an aquifer, therefore these values only represent a portion of the aquifer tested. b) Using a variety of aquifer testing methods can lead to inconsistent results. c) The high variability of the transmissivity in the confined aquifer can produce large uncertainties when extrapolating observed values throughout the study area.

2. Potentiometric surfaces / Head differentials - a) Head potential values from observation wells can contain errors due to inaccurate reading and faulty well surveying. b) Measurements may not be a good representation of the aquifer due to penetration depth or variable characteristics of the aquifer's hydrogeologic properties (i.e., "perched" readings due to clay lenses). c) Errors also result from averaging and extrapolating observed values throughout the study area.

3. Head differentials are constant with time - Head differential for the steady state period of 1977-1979 do not exist for the confined aquifer and hence were estimated. A head differential computed for 1982 was used.

4. Potentials derived from the unconfined aquifer model-Most of the residual errors in the modeled unconfined potential surface must be considered reasonable and minimal when compared to previous studies (Kipp et al., 1972). Leakage calculations in this study, 
though, require smaller residuals in these modeled potentials, since leakage is proportional to the head differential. The largest residual errors are located south of Gable Mountain, and in the vicinity of $B$ Pond. 
CHAPTER IV

MODEL CALIBRATION AND RESULTS

\section{INPUT PARAMETERS ADJUSTED IN CALIBRATION}

\section{Source Term}

Vertical head gradients, interpreted from well data and shown in Figure 12, are upward in the majority of the study site. This condition, which implies that the confined aquifer's potential is greater than the unconfined aquifer's potential, is modeled by adding a flux volume to the uppermost confined aquifer. This volume can be given to portions of the confined aquifer in the following forms (as shown in Figure 9):

a. upward leakage from the deeper confined aquifers

b. downward leakage from the overlying unconfined aquifer

c. recharge where the aquifer outcrops in nearby Gable Mountain

Leakage can be incorporated in the model in two ways. First, the model can calculate the leakage between the two aquifers, as previously described by giving the effective hydraulic conductivity as input, and the vertical gradient computed in the model. Another approach is to simply give the model an estimated leakage volume as a source term. This second method is more suited for the Gable Mountain Pond and B Pond area due to limited confined aquifer potential data and relatively high residuals in the potential surface 
of the unconfined aquifer (see Appendix A) making it difficult to estimate the vertical hydraulic gradient. Leakage is calculated by the model in the remainder of the site and will be discussed in the interaquifer transfer coefficient section.

Upward Leakage from Deep Confined Aquifers. Flux from deep confined aquifers can act as recharge to the uppermost confined aquifer (see flux component $q_{2}$, Figure 9). Faulting and fractures associated with the folded strata in the study area (see Structural Map, Figure 4) may act as avenues for enhanced vertical leakage. Evidence from regional potentiometric data (shown in Figure 10) suggest the study site is in an area of discharge for the confined aquifer system. This could produce the gradient direction necessary for upward leakage to the Rattlesnake Ridge aquifer.

The spatial distribution of this intercommunication is unknown, but regional potentiometric values shown in Figure 10 suggest that vertical leakage from the deeper aquifers is most likely uniform over the entire site. If the leakage was concentrated instead in small zones, areas of steeper hydraulic gradients in the confined aquifer would have been observed.

The magnitude of this upward leakage is limited since the vertical hydraulic gradient observed within the deeper confined system is extremely smal1. Figure 11 shows this gradient in a comparison of head values of the unconfined, Rattlesnake Ridge, and Mabton aquifers (refer to stratigraphic section in Figure 2). An upper bound leakage rate is estimated, by assuming that this flux alone is not adequate enough to produce a significant mound in the 
Rattlesnake Ridge aquifer. An upper bound flux of $9.1 \times 10^{-5}$ meter/day $\left(3 \times 10^{-4}\right.$ feet/day) was found. This would produce $300 \mathrm{ft}^{3} /$ day per $10^{6}$ square foot nodal area (VTT input units). Model nodes are described in Appendix B.

Three zones outlining the estimated distribution of this upward leakage are shown in Figure 14. The largest flux is assigned to areas in the vicinity of folded basalt (see Figure 4). The southern zone is given the smallest value, which is located furthest away from the folded area. An intermediate value is assigned to the remaining northern zone, south of Gable Mountain.

Three conditions defining the magnitudes of these three zones were defined for this study (see Table $V$, Conditions $A, B$, and $C$ ). Varying the distribution of upward leakage in three conditions was thought to be adequate in evaluating the sensitivity of changing this component. The values assigned to these conditions, chosen in an arbitrary manner, while remaining within the bounds previously mentioned, are shown in Table VI. 
TABLE VI

UPWARD LEAKAGE VALUES

\section{Zones of Leakage}

CONDITION

A meter/day $3 \times 10^{-5}$ $\mathrm{ft}^{3} /$ day

B meter/day $\mathrm{ft}^{3} /$ day

C meter/day $\mathrm{ft}^{3} /$ day
HIGHEST

100

$6 \times 10^{-5}$

200

$9 \times 10^{-5}$

300
INTERMEDIATE

$$
7 \times 10^{-6}
$$

25

$1 \times 10^{-5}$

50

$2 \times 10^{-5}$

75
LOWEST<smiles>[124Os]</smiles>

10

$6 \times 10^{-6}$

20

$9 \times 10^{-6}$

30

(see Figure 14)

Values given in units of $\mathrm{ft}^{3} /$ day represent flux to model nodal area of $10^{6} \mathrm{ft}^{2}$ (input to VTT), while values given in meter/day represent flux per unit area.

Downward Leakage from Unconfined Aquifer. The elevated potentials of the unconfined aquifer located in the waste disposal areas (see Figure A.1., Appendix A) produce a downward gradient between the unconfined and confined aquifers (see flux component $q_{1 b}$, Figure 9). Unfortunately, there are only a few wells in this area to obtain data for defining the extent and magnitude of this leakage. Figure A.2. shows well locations used in estimating the extent and magnitude of the elevated potential surface. Figure 12 shows location of data points used in estimating head differentials, and Figure 15 shows locations of wells used in defining thickness 

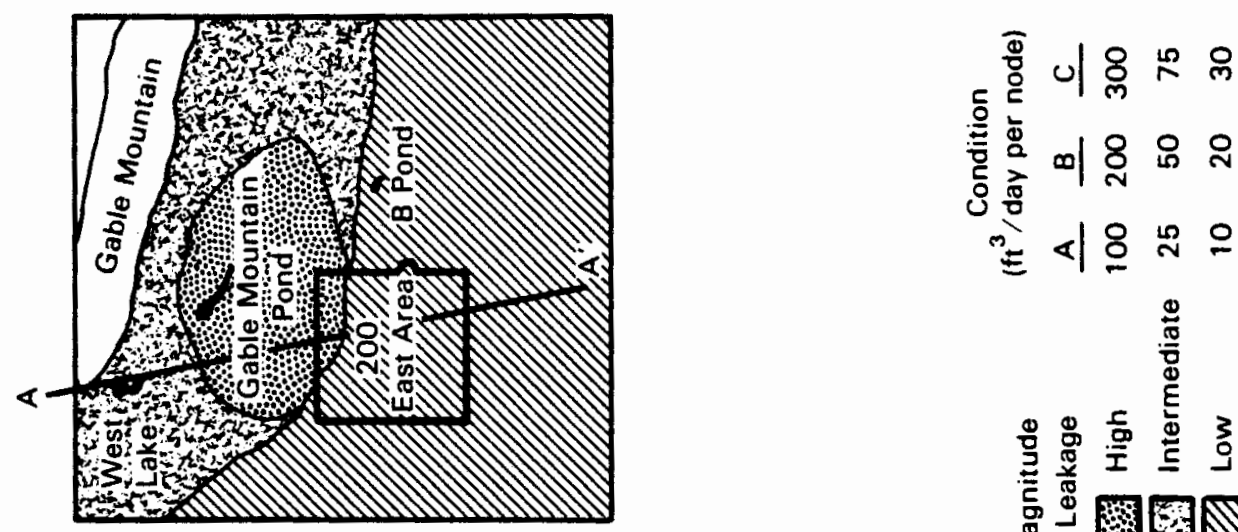

总

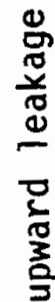

4

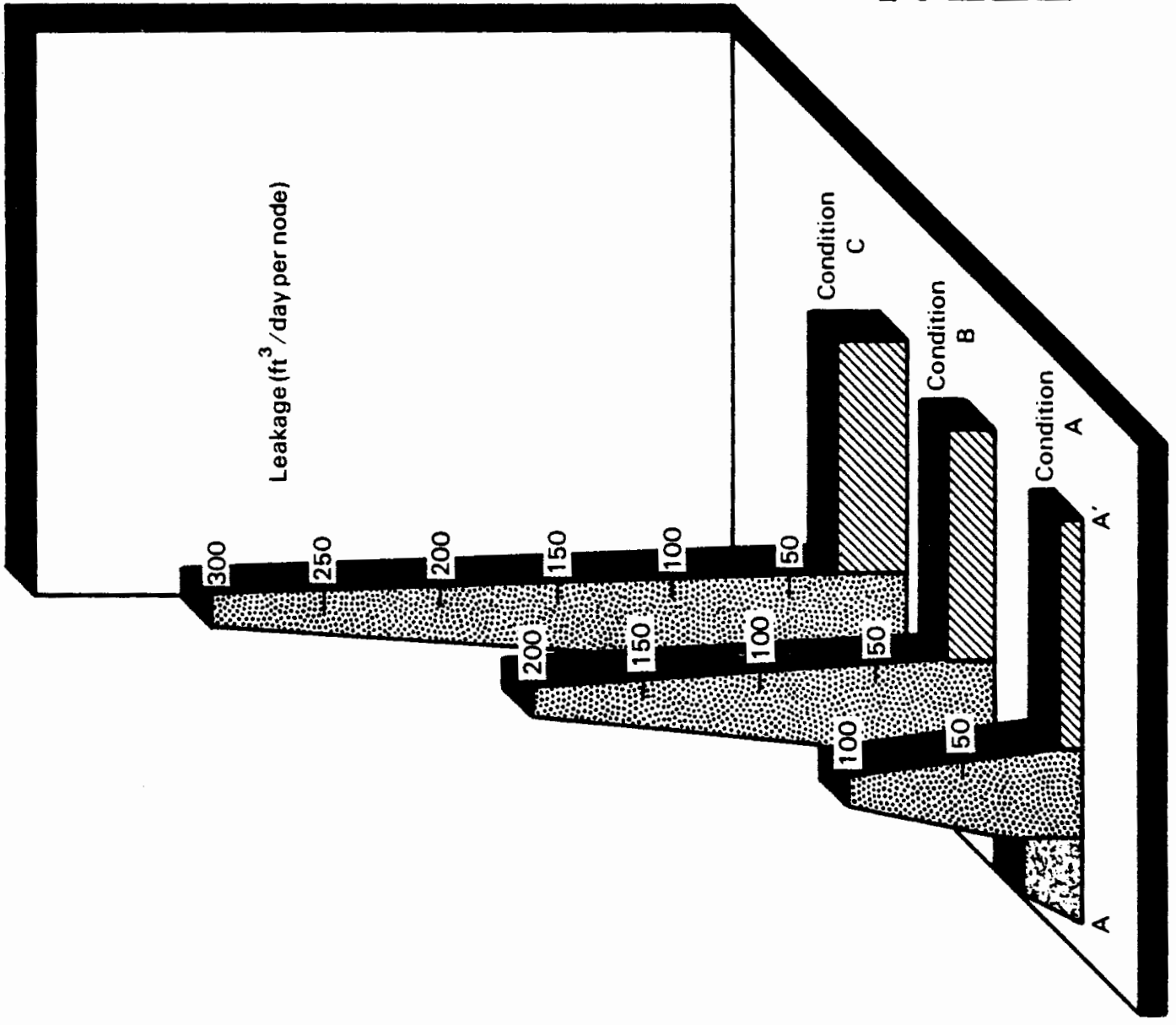

ธ

폴

紊

훙

톤 䎡

-

넌

$\vdots 4$

号 $\overline{0}$

$4<$

응

․․․

든

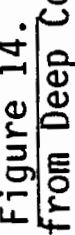




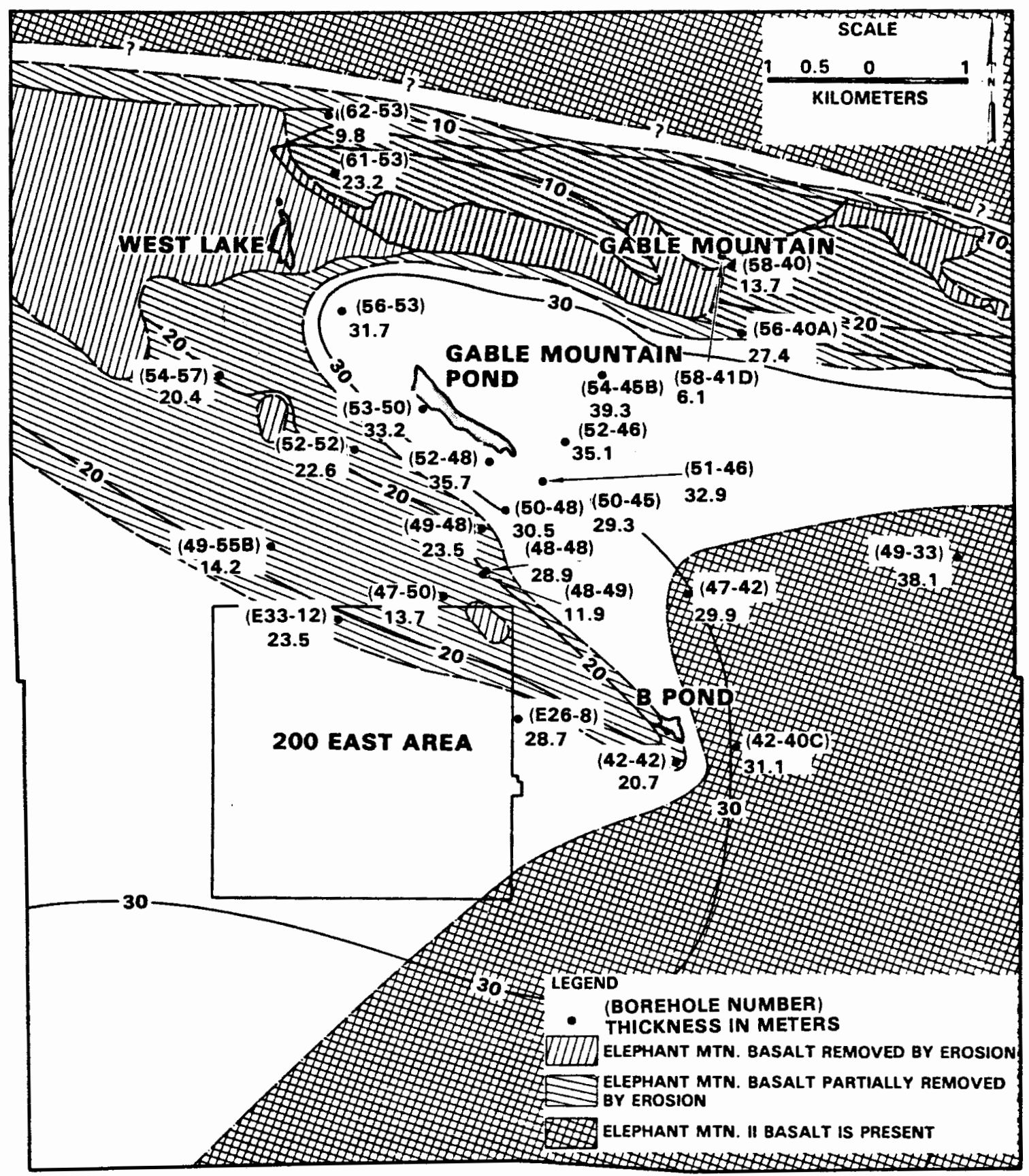

Figure 15. Isopach map of the Elephant Mountain Member (modified from Graham, 1984). 
of the confining layer that separates the two aquifers in this. The range of leakage, downward from the unconfined aquifer to the Rattlesnake Ridge aquifer, can be estimated by:

$$
q=K e / b * \Delta h
$$

where

$q=$ downward leakage from unconfined aquifer per unit area $(l / t)$.

$K_{e}=$ effective hydraulic conductivity of confining layer (Elephant Mountain Member), estimated to range between .001 and .03 meter/day (.01 and .1 feet/day) (Summer and Weber, 1978, and Deju and Fecht, 1979) $(l / t)$

$b=$ thickness of confining layer, estimated to range between 15 and 30 meters (50 and 100 feet) in the vicinity the of disposal ponds (see Figure 15) (l)

$\Delta h=$ head differential between aquifers in vicinity of disposal pond, estimated to range from 1.5 and 7.6 meters ( 5 and 25 feet) (see Figure 12) (l)

$\mathrm{K}_{\mathrm{e}} / \mathrm{b}$ is referred to as the interaquifer transfer coefficient $(1 / t)$ 
Given the range of values above, the corresponding range of leakage is computed as:

Ke $\quad / \quad b \quad * \quad \Delta h=\quad q \quad \begin{gathered}\text { total flux per } \\ \text { model node (VTT input) }\end{gathered}$

lowest leakage

$.001 \mathrm{~m} / \mathrm{d} / 30.5 \mathrm{~m} * 1.5 \mathrm{~m}=.0001 \mathrm{~m} / \mathrm{d}$

$(.01 \mathrm{ft} / \mathrm{d}) /(100 \mathrm{ft}) *(5 \mathrm{ft})=(.0005 \mathrm{ft} / \mathrm{d}) \quad\left(500 \mathrm{ft}^{3} / \mathrm{day}\right)$

highest leakage

$.03 \mathrm{~m} / \mathrm{d} / 15 \mathrm{~m} \quad * 7.6 \mathrm{~m}=.01 \mathrm{~m} / \mathrm{d}$

$(.1 \mathrm{ft} / \mathrm{d}) /(50 \mathrm{ft}) *(25 \mathrm{ft})=(.04 \mathrm{ft} / \mathrm{d}) \quad\left(42000 \mathrm{ft}^{3} / \mathrm{d}\right)$

The range of leakage to the Rattlesnake Ridge aquifer was estimated to be between .0001 meter/day $(.0005 \mathrm{ft} /$ day $)$ and .01 meter/day (.04 ft/day) per unit area. This is equivalent to a range of $500 \mathrm{ft}^{3} /$ day and $42000 \mathrm{ft}^{3} /$ day per nodal area of $10^{6} \mathrm{ft}^{2}$ (VTT input units). This upperbound value of .01 meter/day (42000 $\mathrm{ft}^{3} /$ day per node) may be excessive when compared with the maximum values of liquid disposed to the unconfined aquifer (Anderson and Poremba, 1978; Anderson and Poremba, 1979; Sliger, 1979). A value of 500,000 $\mathrm{ft}^{3} /$ day per model node was estimated to be the maximum measured rate to a model node of area $10^{6} \mathrm{ft}^{2}$.

Values assigned to the downward leakage distribution of the source term were varied in five conditions in Table VII below (also see Table $V$, Conditions $D-H$ ). More conditions were necessary to test the range of the downward leakage than the upward leakage (previousiy described) because of the relatively large range of possible values indicated. 
TABLE VII

DOWNWARD LEAKAGE VALUES

Condition

\begin{tabular}{ccc} 
& \multicolumn{2}{c}{ B POND } \\
& $\begin{array}{c}\text { meter/day } \\
\text { (per unit area) }\end{array}$ & $\begin{array}{c}\text { cu.ft./day } \\
\text { (per node) }\end{array}$ \\
D & .0002 & 500 \\
E & .0003 & 1000 \\
F & .0006 & 2000 \\
G & .0012 & 4000 \\
H & .0024 & 8000
\end{tabular}

Leakage Magnitude

\begin{tabular}{cc}
\multicolumn{2}{c}{ GABLE MOUNTAIN POND } \\
$\begin{array}{c}\text { meter/day } \\
\text { (per unit area) }\end{array}$ & $\begin{array}{c}\text { (per node) } \\
\text { (per nay }\end{array}$ \\
.0001 & 250 \\
.0002 & 500 \\
.0003 & 1000 \\
.0006 & 2000 \\
.0012 & 4000
\end{tabular}

Leakage values assigned to the $B$ Pond area in Conditions D - H ranged from .0002 meter/day $\left(500 \mathrm{ft}^{3} /\right.$ day) to .0024 meter/day (8000 $\left.\mathrm{ft}^{3} / \mathrm{day}\right)$, while the leakage assigned to the Gable Mountain pond area ranged from .0001 meter/day $\left(250 \mathrm{ft}^{3} /\right.$ day) to .0012 meter/day $(4000$ $\mathrm{ft}^{3} /$ day) (Figure 16). Condition $D$ was assigned the lower bound value (previously computed), while Conditions E - H were assigned larger values, increased successively by a factor of two. A maximum value of .0024 meter/day was assigned as the upper bound for downward leakage since the model error increased dramatically with this value as input.

An estimate of the spatial extent of this leakage is shown in Figure 16. Nodes containing the two ponds are assigned the highest leakage, with adjacent nodes given smaller amounts, depending on the estimated trend of the vertical gradients. For example, nodes to the west of Gable Mountain Pond were given relatively smaller values than to the east, due to the anomalously low potential reading at 


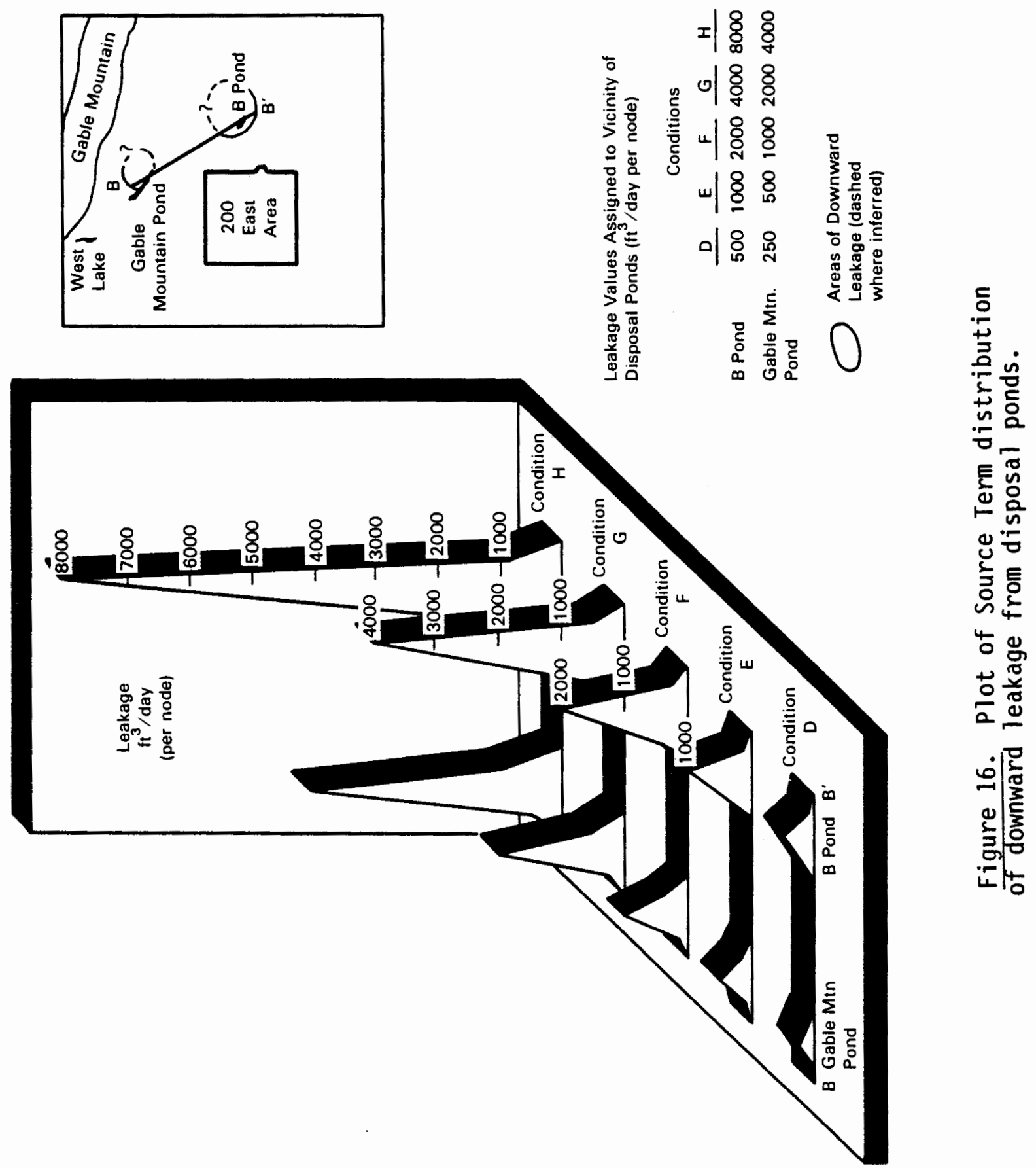


well 699-55-50C (see Figure A.2., Appendix A), suggesting that the mound may be limited to the eastern portion of the pond. Nodes to the south of the pond contain no leakage because the basalt outcrops above the water table. The gradient of the unconfined aquifer is much steeper to the west of the pond. Leakage originating from the $B$ Pond mound is assigned greater values than from Gable Mountain Pond mound because of $B$ Pond's relatively higher unconfined potentials observed from well data (see Figure A.1., Appendix A). Also, the isopach map of the Elephant Mountain Member (Figure 15) suggests that this confining layer has a relatively smaller thickness in the $B$ Pond area, which would increase the possibility of leakage.

Recharge from Gable Mountain. Strait and Moore (1982) suggest that recharge from Gable Mountain could possibly produce the westward flow lines, but give no direct evidence for this occurance. Therefore, this source term option will be considered only for Group IV. Three $(I, J$, and $K$ ) are tested in Group IV, depicting fluxs of $1.5 \times 10^{-5}, 4.5 \times 10^{-5}$, and $1.5 \times 10^{-4}$ meter/day (per unit area) given to nodes outlining the southern flanks of Gable Mountain. This is equivalent to 50,150 , and $500 \mathrm{ft}^{3} /$ day (per unit node).

\section{Interaquifer Transfer Coefficient}

Leakage between the Rattlesnake Ridge Interbed and the unconfined aquifer is also incorporated into the model by allowing this flux to be calculated within the simulation run (by VTT) and is a function of a interaquifer transfer coefficient (an input parameter) and the vertical head differential (difference between the unconfined aquifer's (held) potentials and the potentials modeled 
for the confined aquifer). In the vicinity of the waste disposal ponds, the interaquifer transfer coefficient was set to zero and leakage was included instead in the source term.

Leakage between the unconfined aquifer and the Rattlesnake Ridge aquifer is related to the relative thickness of the confining layer (Elephant Mountain Member), which separates the two aquifers. A smaller thickness may create a shorter path for intercommunication to occur. Also, scouring of this member may have released overburden pressure to produce and enlarge fractures. The distribution and magnitude of the interaquifer transfer coefficient (shown in Figure 17) is represented in three zones based on the isopach map of the Elephant Mountain layer (see Figure 15). The oblong shaped zone, which represents the area of deepest scour along an ancient flood channel's major path through Gable Gap, was assigned the highest interaquifer transfer coefficient. The remaining northern portion's thickness is greater and therefore has a much smaller magnitude. The southern portion was assigned the smallest coefficient since the scouring potential of the flood water channel lessened as the channel spread out.

Plausible values of the confining layer's (Elephant Mountain Member) hydraulic conductivity and thickness allowed a range of interaquifer transfer coefficients $\left(K_{e} / b\right)$ to be estimated (Table VIII).

The interaquifer transfer coefficient is varied for six conditions with values tabulated above, represented in Table $V$ and further illustrated in Figure 17. The set of values for each 
TABLE VIII

VALUES OF INTERAQUIFER TRANSFER COEFFICIENT

\begin{tabular}{|c|c|c|c|}
\hline \multirow[t]{2}{*}{ Condition } & \multicolumn{3}{|c|}{ Zones of Interaquifer Transfer Coefficient } \\
\hline & HICH & INTERMEDIATE & Low \\
\hline \multicolumn{4}{|l|}{ L } \\
\hline $1 /$ day & $3 \times 10^{-6}$ & $1.5 \times 10^{-5}$ & $9 \times 10^{-6}$ \\
\hline$f t^{2} / d a y$ & 100 & 50 & 36 \\
\hline \multicolumn{4}{|l|}{ M } \\
\hline $1 /$ day & $6 \times 10^{-5}$ & $3 \times 10^{-5}$ & $2 \times 10^{-6}$ \\
\hline $\mathrm{ft}^{2} /$ day & 268 & 100 & 68 \\
\hline \multicolumn{4}{|l|}{ N } \\
\hline $1 /$ day & $1 \times 10^{-4}$ & $8 \times 10^{-5}$ & $4 \times 10^{-5}$ \\
\hline $\mathrm{ft}^{2} / \mathrm{day}$ & 490 & 200 & 120 \\
\hline \multicolumn{4}{|l|}{0} \\
\hline $1 /$ day & $2 \times 10^{-4}$ & $1 \times 10^{-4}$ & $7 \times 10^{-5}$ \\
\hline$f t^{2} / d a y$ & 860 & 400 & 240 \\
\hline \multicolumn{4}{|l|}{$P$} \\
\hline $1 /$ day & $5 \times 10^{-4}$ & $2 \times 10^{-4}$ & $1 \times 10^{-4}$ \\
\hline $\mathrm{ft}^{2} /$ day & 1600 & 890 & 480 \\
\hline \multicolumn{4}{|l|}{ Q } \\
\hline $1 /$ day & $1 \times 10^{-3}$ & $5 \times 10^{-4}$ & $3 \times 10^{-4}$ \\
\hline $\mathrm{ft}^{2} / \mathrm{day}$ & 3200 & 1866 & 960 \\
\hline
\end{tabular}

Units of $1 /$ day represent values per unit area, while $\mathrm{ft}^{2} /$ day represent values per nodel node.

$$
\begin{aligned}
& K_{e}=.801 \text { meter/day (.01 feet/day) to } .03 \text { meter/day (.1 feet/day) } \\
& \text { (Summer and Weber, 1978, and Deju and Fecht, 1979) } \\
& b=15 \text { to } 45 \text { meter (50 to } 150 \text { feet) (fron Figure 15) } \\
& K_{e} / b \text { (lower bound) }=2 \times 10^{-5} \text { meter } / \text { day } / \text { meter or } 1 / \text { day } \\
& \left(60 \mathrm{ft}^{2} /\right. \text { day per node) } \\
& K_{e} / b \text { (upper bound) }=2 \times 10^{-3} 1 / \text { day } \\
& \text { (2600 } \mathrm{ft}^{2} / \text { day per node) } \\
& \text { (nodal area }=1 \times 10^{8} \mathrm{ft}^{2} \text { ) }
\end{aligned}
$$




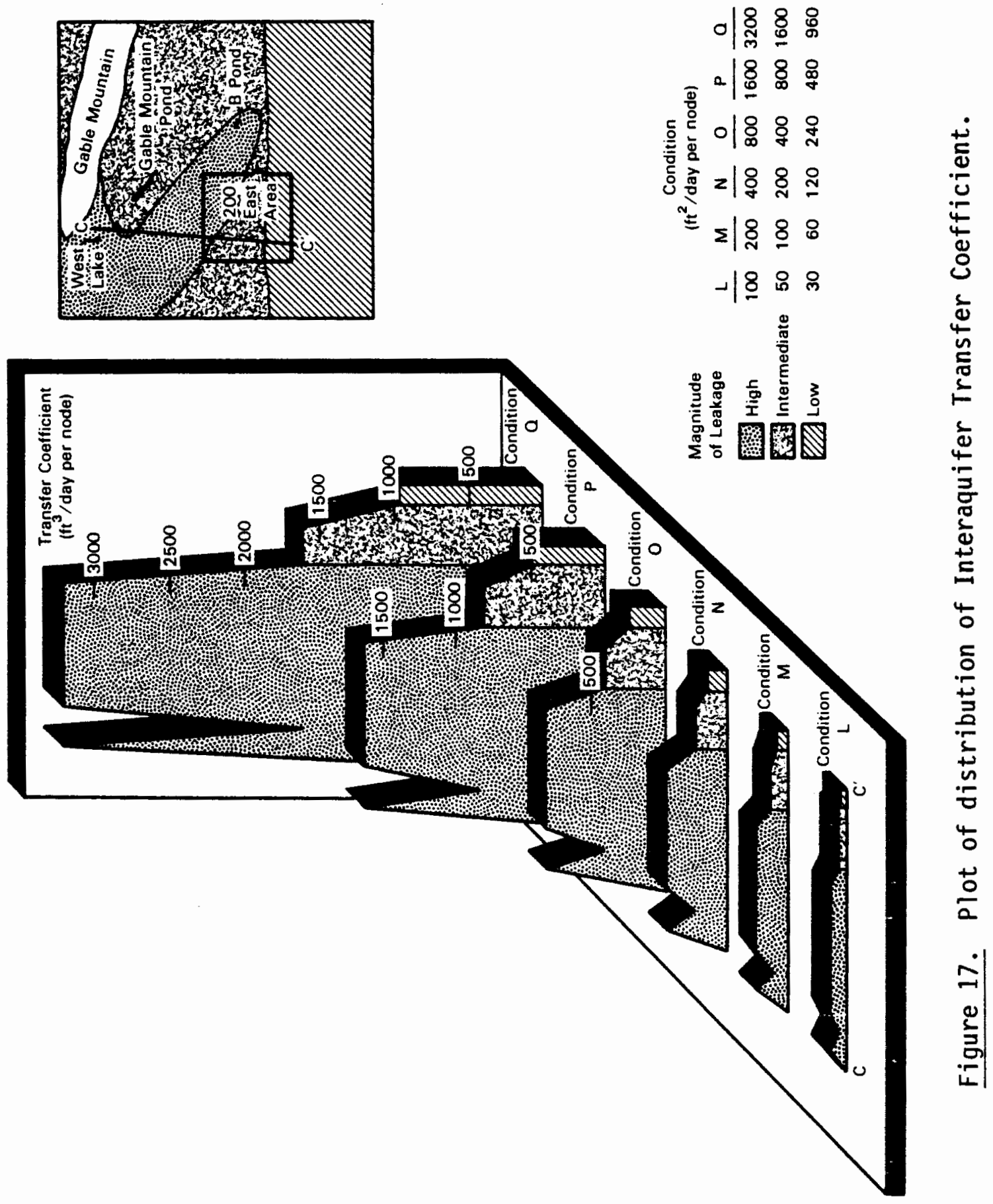


condition is successively increased a factor of 2 . Since the model was found to be rather sensitive to this variabie, values for Conditions $L$ and $Q$ were included in the analysis, even though their magnitudes fall outside the bounds of $2 \times 10^{-5} 1 /$ day and $6 \times 10^{-4} 1 /$ day previously defined.

Hydraulic Conductivity

The hydraulic conductivity values given in Figure 7 were computed from transmissivity values (Graham et a1., 1984) derived from aquifer pump tests on 13 wells penetrating the confined aquifer. Two regions outlined in Figure 7 were found to have relatively lower values of hydraulic conductivity. A reduction of hydraulic conductivity could furthermore increase the confined aquifer's potential in the region.

Three conditions represent the hydraulic conductivity surface (Table $V$ ). The first two conditions represent simple uniform distributions of the (1) average value of all measurements (Condition $R, 2$ meter/day), and (2) twice the average (Condition S, 4 meter/day). The third condition (Condition $T$ ) differentiated the study area into two regions, consisting of a region of relatively low hydraulic conductivity, and a region consisting of the remaining area (shown in Figure 7). The region of low hydraulic conductivity was assigned an average value from the lower measurements (.5 meter/day), and the remaining region has an average value of all measurements (2 meter/day) assigned. 
Boundary Conditions

Boundary conditions were estimated in two ways, as previously described in the "model strategy" section:

1. Groups I through VI assume a relationship between the unconfined and the confined aquifers that allow the use of the unconfined aquifer's boundary potentials to be used as a datum surface for the estimation of the confined aquifer's boundary potentials (Condition $U$ ).

2. Groups VII consists of two conditions. The first (Condition $V$ ) assumed a simple regression through the 13 data points by extrapolating a flat plane out to the confined aquifer's boundaries. The second Condition (W), further investigated the model's sensitivity to the estimated boundary conditions by arbitrarily varying the boundaries in Condition $V$.

The strategy behind the first estimation (Groups I through VI) has more feasibllity when compared with the second (Group VII). A regression as an estimator of boundary vaiues (Group VII) is not applicable to a model with a small spatial distribution of data points, as is represented in this study. The small region where data exists may not be representative of the entire study area i.e., the data may characterize only a localized hydrologic trend.

Knowledge of the system's physics futhermore supports the choice of the first estimation of boundary head values. Within areas of intercommunication between the Rattlesnake Ridge aquifer and the unconfined aquifer, evidence shows the two aquifers linked, i.e., the confined aquifer's potential track those of the unconfined 
aquifer. Therefore, by mimicking the unconfined aquifer, the confined aquifer should take on similar flow patterns.

\section{RESULTS}

The twenty-eight simulation runs were evaluated on three criteria:

1) how well the simulated results "matched" observations (i.e., flow as interpreted from Figures 6 and 12).

2) the simulation's credibility i.e., the ability to match the conceptual model proposed and the regional system understanding discussed (and remain in the ranges of parameter values tabulated in previous section).

3) the model's sensitivity to variation of given parameters. The strategy of calibration in this study is to choice one simulation run from each of the seven groups in Table $V$ to represent the best match. The selection is performed in seven stages, so that each run uses the previous best choose. Therefore Group VII consists of the best matches of Group I - Group VI. The values given for parameters characterizing each simulation run are compared with the range of plausible magnitudes given in the calibration model section. If the magnitude chosen is found to be representative, then the next group is evaluated with the chosen value, and so on. This strategy makes the sensitivity analysis more manageable given the large number of variations possible.

Quantification of the simulations's "match" (of the first criteria described) was accomplished by computing the root mean 
square (RMS) of the difference between the simulated head differentials and the interpreted head differentials, averaged for 1982-1983 (Figure 12). The RMS difference, commonly referred to as a residual, error, or residual error, is defined as (Bevington, 1969):

$$
\text { RMS }=\left[1 / N\left[\left(h_{s}-h_{i}\right)^{2}\right]^{\cdot 5}\right.
$$

$h_{s}=$ simulated head differentials

$h_{i}=$ interpreted (from data) head differentials

$N=$ number of measurements

The errors representing these 28 simulation runs are quantified in two different ways:

1. Well residual - referred to the error calculated for only the 13 data points.

2. Site residual - referred to the error calculated for the entire site. An average head differential interpreted from the data was subtracted from the modeled head differential surface. Hence, this error represents a biased residual in that the comparison involves an interpreted surface of the conceptual model. Residuals of the seven groups are plotted in Figure 18. Three error curves are plotted for each run: one represents the trend of the errors for the site residual, another the well residual, and the third, a mean value of the two previous curves. Not only does this tabulation clarify the runs with the least error values, with the combination of Table $V$ and Figures 14, 16, and 17, one can evaluate parameter sensitivity by examining the relative change in error with the 


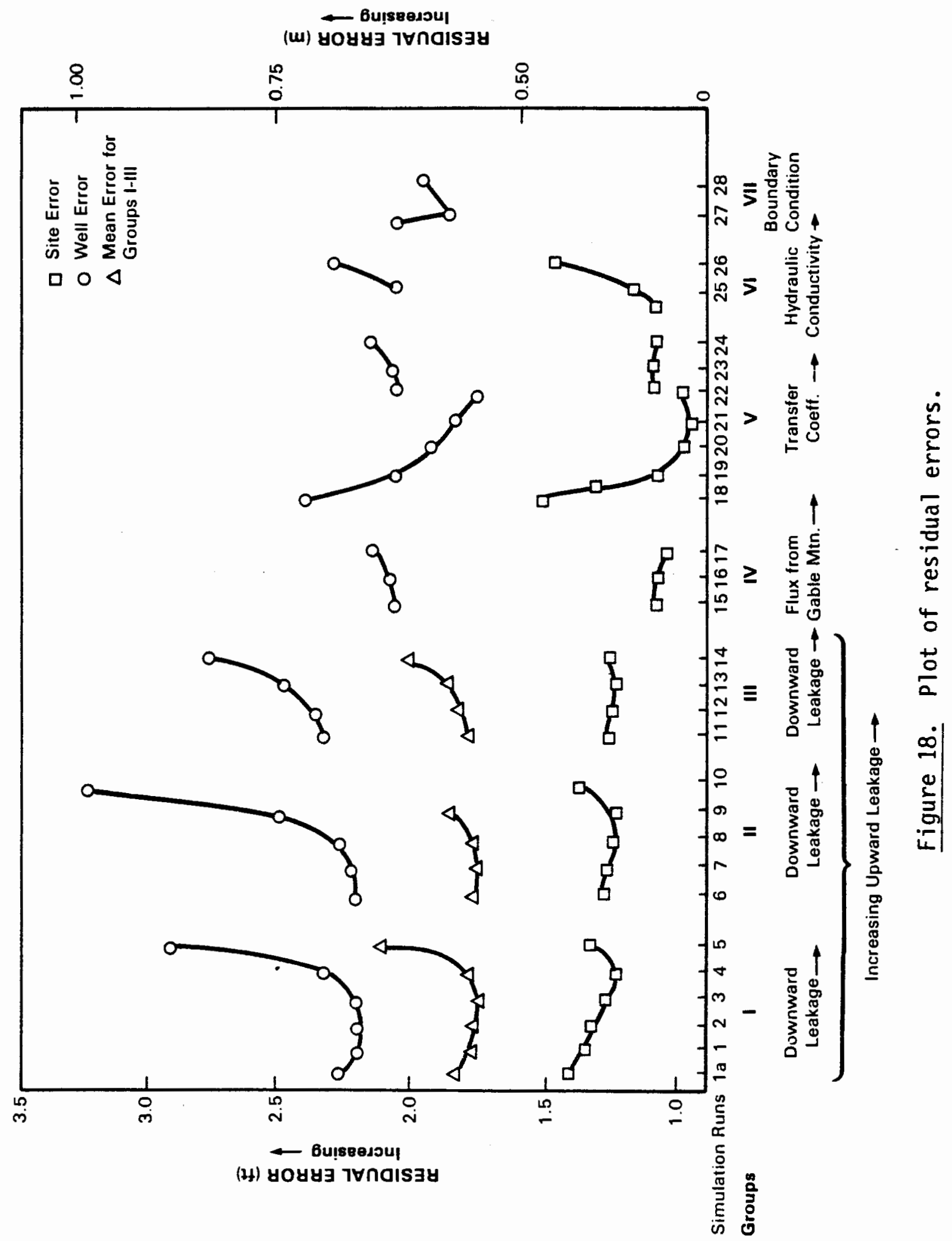


magnitude of parameter variation.

Group I. The five simulation runs of Group I (runs 1-5) show the sensitivity of the downward leakage component (Conditions $D-H$ ) of the source term (Table V). Groups II and III also examine the sensitivity of this term. Downward leakage from $B$ Pond ranges from .0002 meter/day per unit area (p.u.a.) (equivalent to $500 \mathrm{ft}^{3} /$ day per model node) to .0024 meter/day p.u.a. (8000 $\mathrm{ft}^{3} /$ day per model node). Leakage from Gable Mountain Pond ranges from .0001 meter/day p.u.a. (250 $\mathrm{ft}^{3} /$ day per model node) to .0012 meter/day p.u.a. (4000 $\mathrm{ft}^{3} /$ day per model node). These ranges are 11 lustrated for conditions $D$ through $H$ in Figure 16 and tabulated in Table VII. The other parameters remained constant while the five conditions were varied.

The residual error, associated with varying each downward leakage term, is an indicator of the parameter's relative influence to the model. Figure 18 depicts graphically the change in error with variable leakage. The site's residual error decreases in runs $1-4$, while the error increases with run 5 . The error calculated from just the well data points does not show the sensitivity of the source term in runs $1-3$, but is very sensitive to the change made in Condition D. Run la was added to check the sensitivity of decreasing the source term of run 1 . The sharp rise in residual error associated with run 5 has a leakage of .0024 meter/day ( 8000 $\mathrm{ft}^{3} /$ day per model node).

The smallest well error is represented by run 3 , while the site error is smallest in run 4 . When averaging the two error curves, run 3 is found to have the smallest error (Figure 18). 
Group II. Group II also checks the sensitivity of varying the downward leakage term. A larger upward leakage term is incorporated in this group to test its influence. The site's error became less sensitive (relative to Group I), with run 9 the preferred run. The error in the well data points is more sensitive than with Group I, showing a large increase of error in runs 9 and 10 (Conditions $G$ and H), leaving runs 6 and 7 the better choices. Run 7 was found to have the smallest error, with run 8 a close runner up, when the two curves were averaged.

Group III. This group again investigated the sensitivity of the downward leakage component, while incorporating the largest upward leakage term assigned in this model. As expected by the trend outlined in Groups I and II, this added flux from upward leakage has created higher sensitivities of well data error, with run 11 having the least error. The averaged error also shows run 11 as the best choice. A sharp increase in residual error occurs in runs 13 and 14 (Conditions $F$ and $G$ ).

Source Term Discussion. By comparing the residuals of Groups I, II, and III (see Table V, and Figure 18), a best choice to represent the upward leakage term can be found. Group II (containing Condition B), was found to contain the smallest error. of the five simulation runs characterizing the downward leakage sensitivity of Group II (each containing Conditions D - H respectively), run 7 (containing Condition E) has the least error.

A value of effective hydraulic conductivity and interaquifer transfer coefficient associated with each condition (representing 
downward leakage) can be calculated from the relationship (previously described:

$$
q=K e / b * \Delta h
$$

where

Ke $=$ effective hydraulic conductivity of Elephant Mountain Member $b=$ thickness of Elephant Mountain Member $\Delta h=$ head differential between the unconfined and confined aquifer $\mathrm{K}_{\mathrm{e}} / \mathrm{b}$ is referred to as the interaquifer transfer coefficient The effective hydraulic conductivity associated with Condition E was calculated to be roughly .001 meter/day $(.005 \mathrm{ft} /$ day $)$. This represents a lower bound of hydraulic conductivity when compared with the range defined in Table IV (.01 to $.1 \mathrm{ft} /$ day). An interaquifer transfer coefficient associated with Condition $E$ was estimated to be roughly $7 \times 10^{-5} /$ day.

Group IV. Increasing a flux derived from infiltration to the Rattlesnake Ridge Interbed, that outcrops at Gable Mountain, reduced the site but increased the well error. Results are therefore mixed and furthermore, more data would be necessary to prove that this flow component exists. It was not considered further in the remaining analysis.

Group V. The seven simulation runs of Group $V$ examine the sensitivity of the interaquifer transfer coefficient (Table $V$ ). This transfer coefficient is related to the hydraulic conductivity of the Elephant Mountain Member, which also influences the downward leakage from disposal ponds previously tested in Groups I - III (see Figure 9 for illustration of flux components). Therefore, hydraulic 
conductivity values computed from transfer coefficient values of Group V can be compared to values derived from Groups I - III. The choice of source term comes from conditions that make up run 7 (represented the best choice).

The plot of the well error shown in Figure 18 shows a trend of decreasing residual with increasing leakage transfer (runs 18 - 22). This is because the more communication between the aquifers, the more the confined aquifer's potentials resemble the unconfined aquifer, and hence match the small head differential observed on the study site. The residual plot for the site error shows a leveling off of residual change for runs 20,21 , and 22 and begins to increase with run 22.

Runs 23 and 24 further checked the sensitivity of varying the source term. Results show minimal model sensitivity to a reduction in flux from the deep aquifer system (Run 23) but when the flux is increased, (run 24), the well data residual also increases. This verifies the previous choice of Condition B (of run 7) by showing that it remains the best choice even after varying the transfer leakage magnitude.

Smaller residuals were produced with an increased transfer flux. To choose a value of interaquifer transfer coefficient that best represents Group V, results of Groups I - III (downward leakage to the confined aquifer from the unconfined aquifer) were examined. Results of Group I - III were able to help constrain a best choice of interaquifer transfer coefficient for Group $V$ because downward leakage, as previously mentioned, is influenced by the same 
interaquifer transfer coefficient (i.e., related to the effective hydraulic conductivity and thickness of the Elephant Mountain Member) Values of transfer for Group $V$ were compared with the transfer associated with the best choice of downward leakage $\left(7 \times 10^{-5} /\right.$ day) . Values of transfer for Conditions $M$ and $N$ of Group 7 were the closest match to this. The interaquifer transfer coefficient of Condition $\mathrm{N}$ was used in further testing the sensitivity of hydraulic conductivity (Group VI) and boundary conditions (Group VII) that follows. Group VI. Two simulations were run to investigate the sensitivity of the hydraulic conductivity. All previous groups incorporated a variable hydraulic conductivity (Condition $T$ ), while run 25 represents a constant $50 \mathrm{gal} / \mathrm{ft}^{2} /$ day, and run 26,100 $\mathrm{gal} / \mathrm{ft}^{2} /$ day (see conceptual model for details on these magnitudes). Comparing these two runs with run 19 (Condition $T$ ) reveals a relatively large increase in error. Hence, Condition $T$ is chosen to represent the hydraulic conductivity distribution.

Group VII. Three conditions characterize the boundary conditions for the study site. All previous groups used Condition $U$, which utilized the unconfined aquifer's potential as an estimate for potential values. Boundary values for Conditions $V$ and $W$ were derived from fitting a planar regression from data points and extending this plane to boundary nodes. An estimate of boundary values were taken from the potential values at these nodes.

Results of run 27 (with boundaries of Condition $U$ ) and run 19 (with boundaries of Condition V) are illustrated in Figures 19 and 20, respectively. These figures contour resulting potentials and 

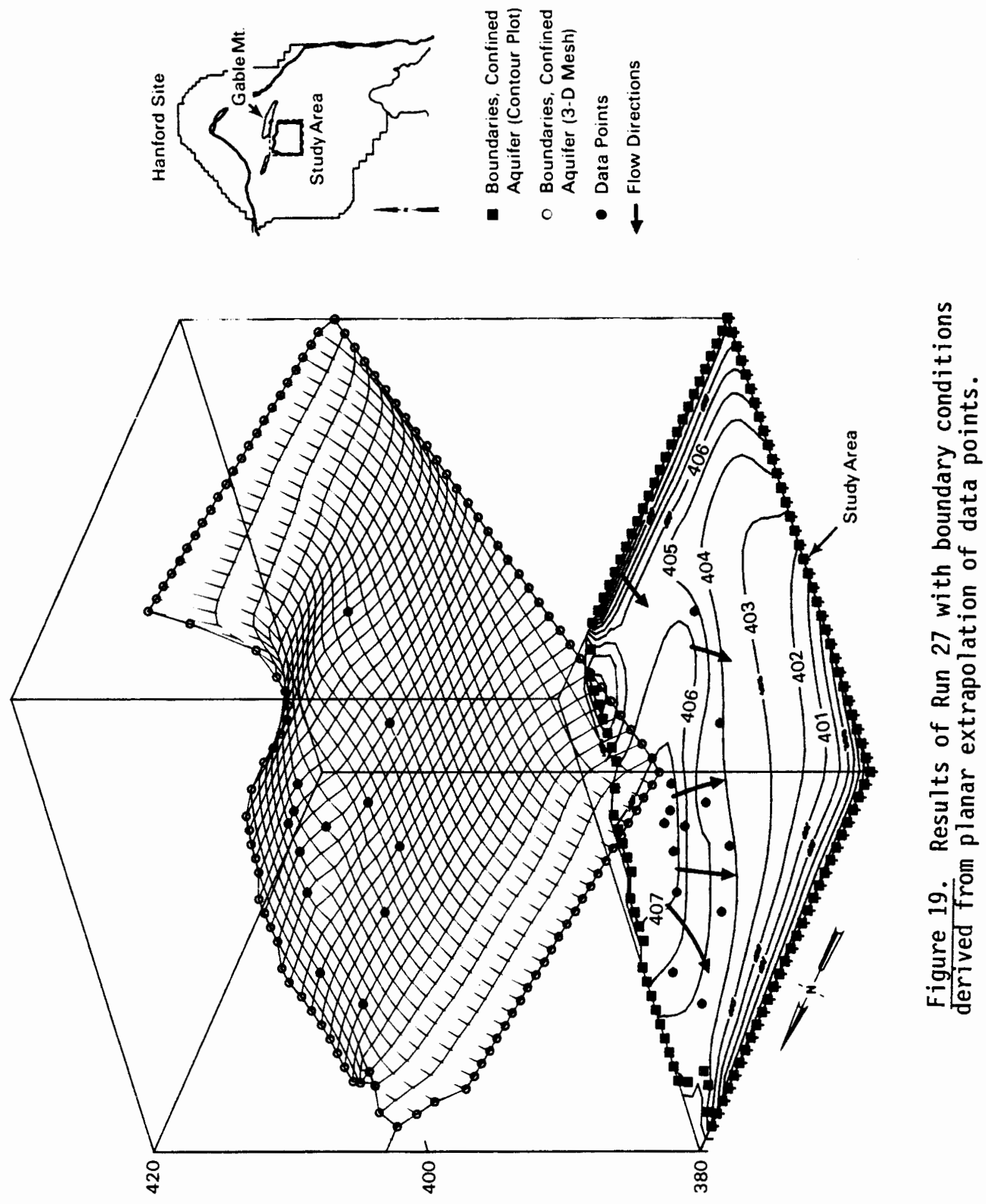

(14) s!e!lualod peaн 

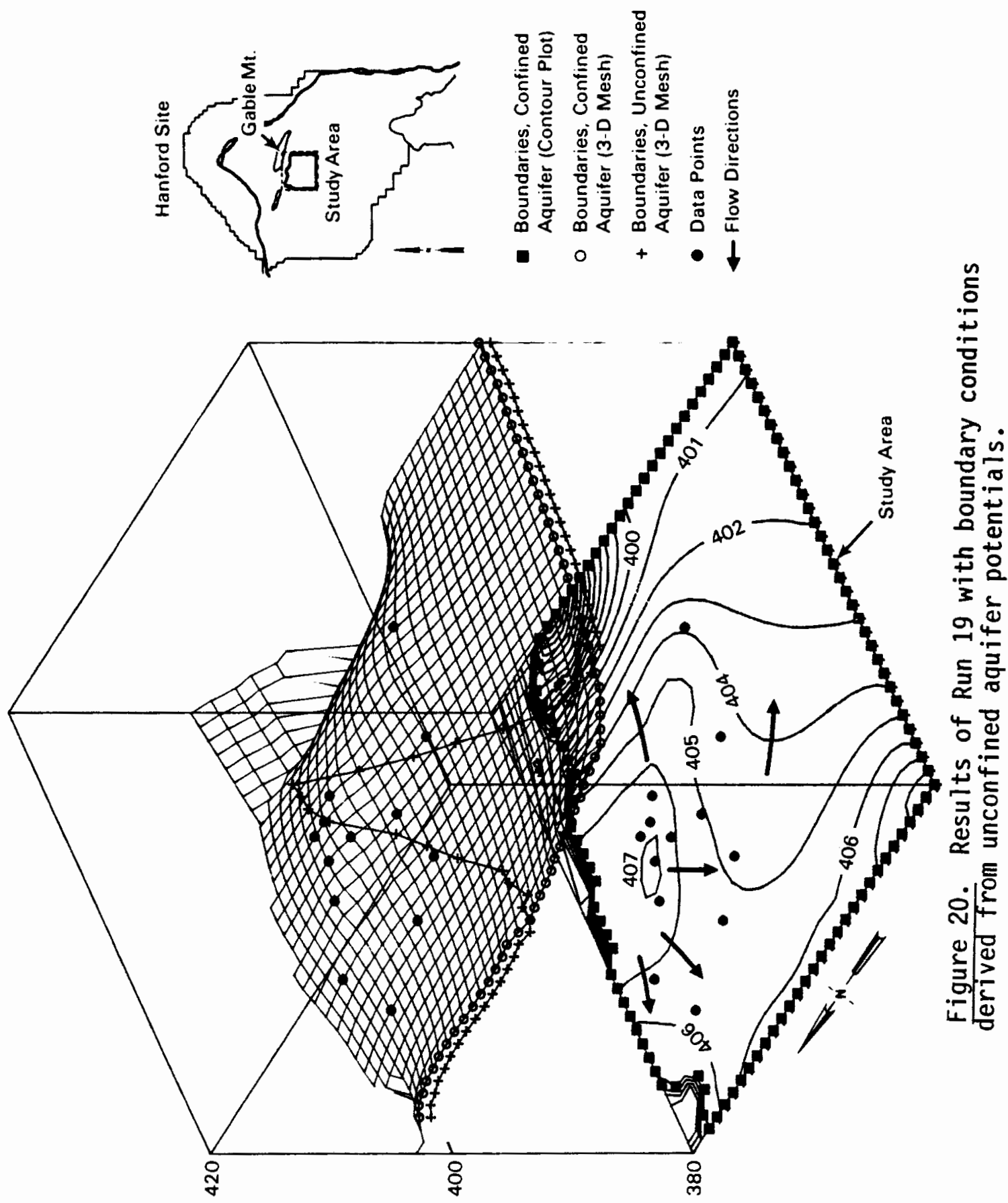

(at) le!lualod реан 
also portray them in a three-dimensional mesh. The difference between these two extremely different boundary conditions are more easily conceptualized by comparing the three-dimensional mesh plots. Figure 20 includes the boundary potentials from the unconfined aquifer (see Appendix A) of which most of the confined boundaries were derived from. Even though the confined aquifer's boundaries in Figures 19 and 20 differ greatly, the results near the center of the two plots are very similar.

Only the well data error was calculated for Conditions $V$ and $W$ (see Figure 18) because comparing the resulting potentials of the entire site with potentials representing a regression from data points would be meaningless.

The regression derived conditions (runs 27 and 28) proved to produce less errors than previous runs (compare with run 19, which consists of the combination of "best choices" calculated previously). This is because the gradient produce by boundaries in Conditions $V$ and $W$ enhance a westward flow direction, while the boundary conditions of Condition $U$ enhance a southward flow direction. In this way, Conditions $V$ and $W$ "work with" the data points, i.e., they don't oppose the data as Condition $U$ does (compare Figures 19 and 20)

The selection of a best condition to represent the boundary conditions for the confined aquifer, in the manner performed previously for the analysis of other model components, was not done since no data exists for calibration. Instead the credibility of each condition, as described in the previous section, is taken into 
consideration. Problems with the credibility of Condition $V$ and $W$ arise from extrapolating a small region of data points, over a large distance. The data may reflect just a localized phenomenon, in a very complex geohydrological setting.

\section{SUMMARY AND CONCLUSIONS}

The study site is located in a regional discharge area for the confined aquifer within the Saddle Mountain Basalt Formation, thereby creating the potential for upward leakage to the unconfined aquifer. Disposal of liquid waste to the unconfined aquifer creates the potential for downward leakage as a result of the associated mounding. Furthermore, results from this study indicate that potentials of the Rattlesnake Ridge confined aquifer are sensitive to this leakage term, perhaps due to the confined aquifer's relatively small transmissivity.

Results show that the observed flow configuration can be simulated as the westward flanks of a ground-water mound produced from leakage between the unconfined and confined aquifers. This implies that leakage through vertical fractures in the basalt can play an important role in the interpretation of the Rattlesnake Ridge Aquifer's flow system and in out understanding of aquifer intercommunication in the study area.

Recharge is produced chiefly from two sources. Leakage from the overlying unconfined aquifer occurs in areas where the unconfined's potential exceeds the Rattlesnake Ridge aquifer's potential principally at and around (Hanford operations) disposal 
areas. Likewise, leakage to the Rattlesnake Ridge aquifer occurs from the underlying deeper basalt aquifers in areas where the deep basalt aquifer's potential exceeds the Rattlesnake Ridge aquifer's potential.

Four components of the model were varied resulting in twenty eight different simulation runs. These components are the source term, interaquifer transfer coefficient, hydraulic conductivity, and boundary conditions. A plausible range of values was determined for each of these. These values were used as simulation run inputs to test and rank the ability of the model to match observed potentials and head differentials. The comparisons are quantified in a form of standard deviation referred to as residual error.

The sensitivity and uncertainty of each component was investigated to rank the importance of data, required to develop a more quantitative model. The sensitivity was demonstrated by observing the relationship between the component's magnitude and its consequence impact on the model results (Figures 14, 16, 17, and 18) in the form of site and well residual errors. Uncertainties are related to the quality and quantity of data available for constraining the magnitude of the various model components and areal distributions. The relative sensitivities and uncertainties of the four components are summarized below:

\section{Source Term}

Upward Leakage. The model is relatively insensitive to this leakage from the deeper aquifers, perhaps because the range of values deemed feasible in the conceptual model is relatively small. The 
uncertainty in this parameter's value is related to the interaquifer transfer coefficient (function of effective vertical hydraulic conductivity and layer thickness) of the Pomona Basalt layer, which separates the deeper aquifers from the Rattlesnake Ridge aquifer, and also the hydraulic gradient between them.

Downward Leakage. Within the upper range of leakage values, model sensitivities become notably higher, but otherwise sensitivities are minimal. The uncertainty of this parameter is related to the head differential in the areas of waste disposal, and the interaquifer transfer coefficient assigned to the Elephant Mountain Member confining layer. No data exists for the head differential, therefore this value was extrapolated from the closest data points. Of more importance is the value of the effective vertical hydraulic conductivity of the eroded basalt confining layer, which is probably a function of the degree of fracturing. (Data to quantify this value is not available).

\section{Interaquifer Transfer Coefficient}

This component dominates model sensitivity and is more important in regions with direct physical contact between the unconfined and confined aquifers.

Uncertainties inherent in the interaquifer transfer coefficient are related to both the effective hydraulic conductivity of the aquitard and vertical head differentials between the unconfined and confined aquifers. The effective hydraulic conductivity of the Elephant Mountain Member was estimated from regional studies since no data exists for the study area. This value is believed to be 
variable since it is dependent on the degree of fracturing, as mentioned previously. Values for head differentials only exist for two areas which contain pieziometer nests, hence the head differences between the two aquifers were estimated from separate but closely spaced wells penetrating the Rattlesnake Ridge confined and the unconfined aquifer.

Hydraulic Conductivity of Interbed

The model is very sensitive to this parameter. Fortunately twelve wells have been tested for this value (Graham et al., 1984), thereby constraining this parameter. These wells are mostly located in the northern portion of the site, where the structure is more complex, and therefore may not be representative of the remainder of the site.

\section{Boundary Conditions}

The range of residual errors, derived from comparing the model results with well data, is relatively insignificant for the three cases of boundary node values (Conditions $U, V$, and $W$ ). The insensitivity of the boundary conditions when comparing results at data point locations (as shown in Figures 19 and 20) occur because well data is mostly located in the portion of the study area that demonstrated the maximum physical contact between the aquifers. As a consequence, leakage dominated the model sensitivity at points where error values were calculated. Note that the two simulated potentiometric surfaces of Conditions $U$ and $V$ (Figures 18 and 19, 
out points confined to a small region. Note the unlikely large vertical head differentials between the unconfined and confined aquifers that are generated on the eastern boundary of the study area (Figure 19).

Values of the unconfined aquifer's potential, which were treated as a held head boundary for leakage calculations in this mode1, are known to contain uncertainties (see Figure A.5., Appendix 1). Residuals were relatively high south of Gable Mountain and in the vicinity of B Pond. Clay lenses may produce anomalous well readings in the Gable Mountain area, and a steep hydraulic gradient may be a problem in the $B$ Pond region.

\section{RECOMMENDATIONS}

A more meaningful calibration of the Rattlesnake Ridge aquifer requires a full three-dimensional analysis. Multiple well tests and piezometer nests that quantify the vertical hydraulic conductivity and record the potential with depth, respectively, would enhance the three-dimensional conceptualization, thereby allowing for a more definitive analysis. Other testing in the form of tracer tests and long-term pump tests could also help investigate the importance and role of aquifer intercommunication in controlling groundwater flow direction and transport of contaminants.

Additional wells penetrating the Rattlesnake Ridge aquifer can help delineate the flow pattern inside and adjacent to the study site. Existing wells are mostly concentrated in a small region on the site, thereby leaving the general flow direction ill-defined. 
Wells into the confined system and located outside this region are necessary for adequate definition of boundary conditions required in future computer models. Wells located northeast of the Separations Area would define the flow direction "upstream" from data points. This would help in investigating the source of the elevated head pattern, observed in the confined aquifer (Figure 6).

One of the most important advantages that future models of the Rattlesnake Ridge aquifer will acquire is a simple record of data produced with time. One year of steady state data used in this study gives only a foundation to work on. 


\section{REFERENCES CITED}

Anderson, J.D., and B.E. Poremba, 1978. Radioactive Liquid Waste Discharged to Ground in the 200 Areas During 1977. RHO-CD-34 4Q, Rockwell Hanford Operations, Richland, Washington

Anderson, J.D., and B.E. Poremba, 1979. Radioactive Liquid Waste Discharged to Ground in the 200 Areas During 1978. RHO-CD-78 4Q, Rockwell Hanford Operations, Richland, Washington

Arnett, R.C. et al., 1976. Conceptual and Mathematical Modeling of the Hanford Groundwater Flow Regime. ARH-ST-140, At Tantic Richfield Hanford Company, Richland, Washington

Arnett, R.C. et a1., 1977b. Hanford Groundwater Scenario Studies. ARH-SA-292, Atlantic Richfield Hanford Company, Richland, Washington

Basalt Waste Isolation Project Staff, 1982. Site Characterization Report for the Basalt Waste Isolation Project. D0E/rl 82-3, 3 volumes, U.S. Department of Energy, Richland, Washington.

Bevington, P.R., 1969. Data Reduction and Error Analys is for the Physical Sciences. McGraw-Hill Book Company, New York, N.Y.

Bredehoeft, J.D., and G.F. P1nder, 1979. Digital Analysis of Areal Flow in Multiaquifer Groundwater systems: A Quas $\hat{i}$ ThreeDimensional Model. U.S. Geological Survey, Washington, D.C. pp 883-888.

Bretz, J.H., 1959. Washington's Channeled Scabland. Washington Mines and Geology, Bulletin 45.

Brown, D.J., 1959. Subsurface Geology of the Hanford Separations Area. HW-61780, General Electric Company, Richland, Washington.

Brown, R.E. and H.G. Rubert, 1950. The Underground Disposal of Liquid Wastes at the Hanford Works, Washington. HW-17088, General Electric Co., Richland, Washington.

Cearlock, D.B., 1971. A Systems Approach to Management of the Hanford Groundwater Basin. BNWL-SA-3860, Battelle Northwest Laboratories, Richland, Washington.

Cearlock, D.B., 1975. Transmissivity Iterative Calculation Routine Theory and Numerical Implementation. BNWL-1706 Battelle Pacific Northwest Laboratories, Richland, Washington. 
Cooper, H.H. and C.E. Jacob, 1946. "A Generalized Graphical Method for Evaluating Formation Constants and Summarizing Well Field History." Trans. Amer. Geophysical Union, pp 526-534.

Deju, D.A., 1974. The Hanford Field Testing Program. ARH-C-004, At lantic Richfield Hanford Company, Richland, Washington.

Deju, D.A., and A.E. Reisenauer, 1976. Evaluation of the Hydrology of the Washington Public Power Supply System and the Fast Flux Test Facility. ARH-ST-140, Atlantic Richfield Hanford Company, Richland, Washington.

Deju. R.A. and K.R. Fecht, 1979. Preliminary Description of Hydrologic Characteristics and Contaminant Transport Potential of Rocks in the Pasco Basin, S. Central Washington. RHO-BWI[D-20, Rockwe $]\rceil$ Hanford Operations, Richland, Washington.

Dove, F.H., et al., 1982. AEGIS Technology Demonstration for a Nuclear Waste Repository in Basalt. PNL-3632, Battelle-Pacific Northwest Laboratory, Richland, Washington.

Fecht, K.R., 1978b. Geology of Gable Mountain/Gable Butte Area. RHO-BWI-LD-5. Rockwe11 Hanford Operations, Richland, Washington.

Fetter, Jr., C.W., 1980. Applied Hydrogeology. Merrill Publishing Co., Columbus, Ohio. $488 \mathrm{pp}$.

Gee, G.W. and P.R. Heller, 1985. Unsaturated Water Flow at the Hanford Site: A Review of Literature and Annotated Bibliography. PNL-5428, Battel7e-Pacific Northwest Laboratory, Richland, Washington.

Gephart, R.E., et al., 1976. Geohydrologic Study of the West Lake Basin. ARH-CD-775, Atlantic Richfield Hanford Co., Richland, Washington.

Gephart, R.E., et al, 1979. Hydraulic Studies Within the Columbia Plateau, Washington: An Intergration of Current Knowledge. RHO-BWI-ST-5, Rockwell Hanford Operations, Richland, Washington.

Graham, M.J. et al., 1981. Hydrology of the Separations Area. RHOST-42. Rockweil 1 Hanford Operations, Richland, Washington.

Graham, M.J., 1984. Hydrogeochemical and Mathematical Analysis of Aquifer Intercommunication, Hanford Site. RHO-RE-SA-43. Rockwell Hanford Operations, Richland, Washington.

Ha11, M.D., 1981. Near Field Impact of 216-U-10 (U Pond) Decommissioning on the Unconfined Aquifer. RHO-LD-157 Rockwell Hanford Operations, Richland, Washington. 
Intera Environmental Consultants, 1976. Hydrologic Model Evaluation at the Hanford Waste Facilities. ARH-C-00017. Prepared for the Atlantic Richfield Hanford Company, Richland, Washington.

James M.L., et al., 1985. Applied Numerical Methods for Digital Computation. Harper \& Row, Publishers, Inc., New York, N.Y. $753 \mathrm{pp}$.

Kipp, K.L., et a1., 1972 (updated 1976), Variable Thickness Transient Groundwater Flow Model: Theory and Numerical Implementation. BNWL-1703, Pacific NW Laboratory, Richland, Washington.

Last, G.V. and K.R. Fecht, 1984. Ground-Water Geology of the Aquifer Intercomminication Study Area. Rockwell Hanford Operations, Richland, Washington.

Ledgerwood, R.K. and R.A. Deju, 1976. Hydrology of the Uppermost Confined Aquifers Underlying the Hanford Reservation. ARH-SA253, Atlantic Richfield Hanford Company, Richland, Washington.

Moore, B.A., 1982. Geophysical Investigations of the Gable Mountain Pond-West Lake Area, Hanford Site, South-Central Washington. RHO-SA-239, Rockwe11 Hanford Operations, Richland, Washington.

Myers, C.W. et al., 1979. Geological Studies of the Columbia Plateau- Status Report. RHO-BWI-ST-4, Rockwell Hanford Operations, Richland, Washington.

Myers, C.W. and S.M. Price, eds. 1981. Subsurface Geology of the Cold Creek Syncline. RHO-BWI-ST-14, Rockwell Hanford Operations, Richland, Washington.

Newcomb, R.C., and J.R. Strand, 1953. Geology and Ground-water Characteristics of the Hanford Reservation of the Atomic Energy Commission, Washington. U.S. Geological Survey WP-8.

Newcomb, R.C., J.R. Strand, and F.R. Frank, 1972. Geology and Ground-water Characteristics of the Hanford Reservation of the Atomic Energy Commission, Washington. U.S. Geological Survey Professional Paper 717.

Parker, G.G. and A.M. Piper, 1949. Geology and Hydrologic Features of the Richland Area, Washington, Relevant to Disposal of Waste at the Hanford Directed Operations of the H.E.C. U.S. Geological Survey, Interim Report No.1 WP-7

Richard, B.H., 1976. Residual Gravity Analysis of Selected Cross Sections of the Hanford Reservation. CA-200-BHR-1, Atlantic Richfield Hanford Co., Richland, Washington. 
Sliger, G.J., 1980. Radioactive Liquid Waste Discharged to Ground in the 200 Areas During 1979. RHO-CD-79-34 4Q, Rockwell Hanford Operations, Richland, Washington.

Stone, W.A., D.E. Jenne, and M.J. Thorp, 1972. Climatology of the Hanford Area. BNWL-1065, Battelle-Pacific Northwest Laboratory, Richland, Washington.

Strait, S.R. and B.A. Moore, 1982. Geohydrology of the Rattlesnake Ridge Interbed in the Gable Mountain Pond Area. RHO-ST-38, Rockwell Hanford Operations, Richland, Washington.

Summers, W.K. and P.A. Weber, 1978. Data for Wells Peneterating Basalt in the Pasco Basin Area, Washington. RHO-BWI-C-19, Rockwell Hanford Operations, Richland, Washington.

Swanson D.A., T.L. Wright, and R.T. Helz, 1975. "Linear Vent Systems and Estimation Rates of Magma Production and Eruption for the Yakima Basalt on the Columbia Plateau." American Journal of Science.

Tallman, A.M., et al., 1979. Geology of the Separations Areas, Hanford Site South-Central Washington. RHO-ST-23, Rockwell Hanford Operations, Richland, Washington.

Theis, C.V., 1935. "The Relation Between the Lowering of Piezometric Surface and the Rate and Duration of Discharge of a Well Using Groundwater Storage." Trans. Amer. Geophysical Union, pp 519524

Wilbur, J.S., M.J. Graham, and A.H. Lu. 1983. Results of the Separations Area Monitoring Network for 1982. RHO-RE-SR-8324P, Rockwell Hanford Operations, Richland, Washington. 
APPENDIX A

MODEL OF THE UNCONFINED AQUIFER 
A model of the unconfined aquifer was developed for the study area. Incorporating unpublished data reported in 1985 helped to improve an existing groundwater flow mode1. Resulting potentials from this revised model was used in calculating leakage between the unconfined and confined aquifers, which is driven by the difference in head potential of the two aquifers.

The unconfined aquifer within the study area consists of Ringold and/or Hanford sediments (Tallman et al., 1979). The aquifer is defined by the water table from above and the Elephant Mountain basalt surface (or the clay member of the Ringold Formation, if it exists) below. This aquifer is discontinuous only in areas where the basalt extends above the water table surface, such as Gable Mountain, Gable Butte, and subcrops south of Gable Mountain. These basalt boundaries are shown in watertable maps of the Hanford Site and the study area (Figure A.1. and A.2., respectively).

The unconfined aquifer has a thickness of over 70 meters within the study area, and thins to zero where the sediments pinch out along the flanks of the basalt ridges (Graham, 1981). The varying thickness of the aquifer and its corresponding formation type, are shown in the cross-sections of Figure 5. The aquifer's thickness increases to the south, in relation to the dip of its underlying basalt.

A groundwater flow model of the Hanford Site which uses the Variable Thickness Transient (VTT) code, is presently being used by contractors of the Department of Energy to predict the rate of 


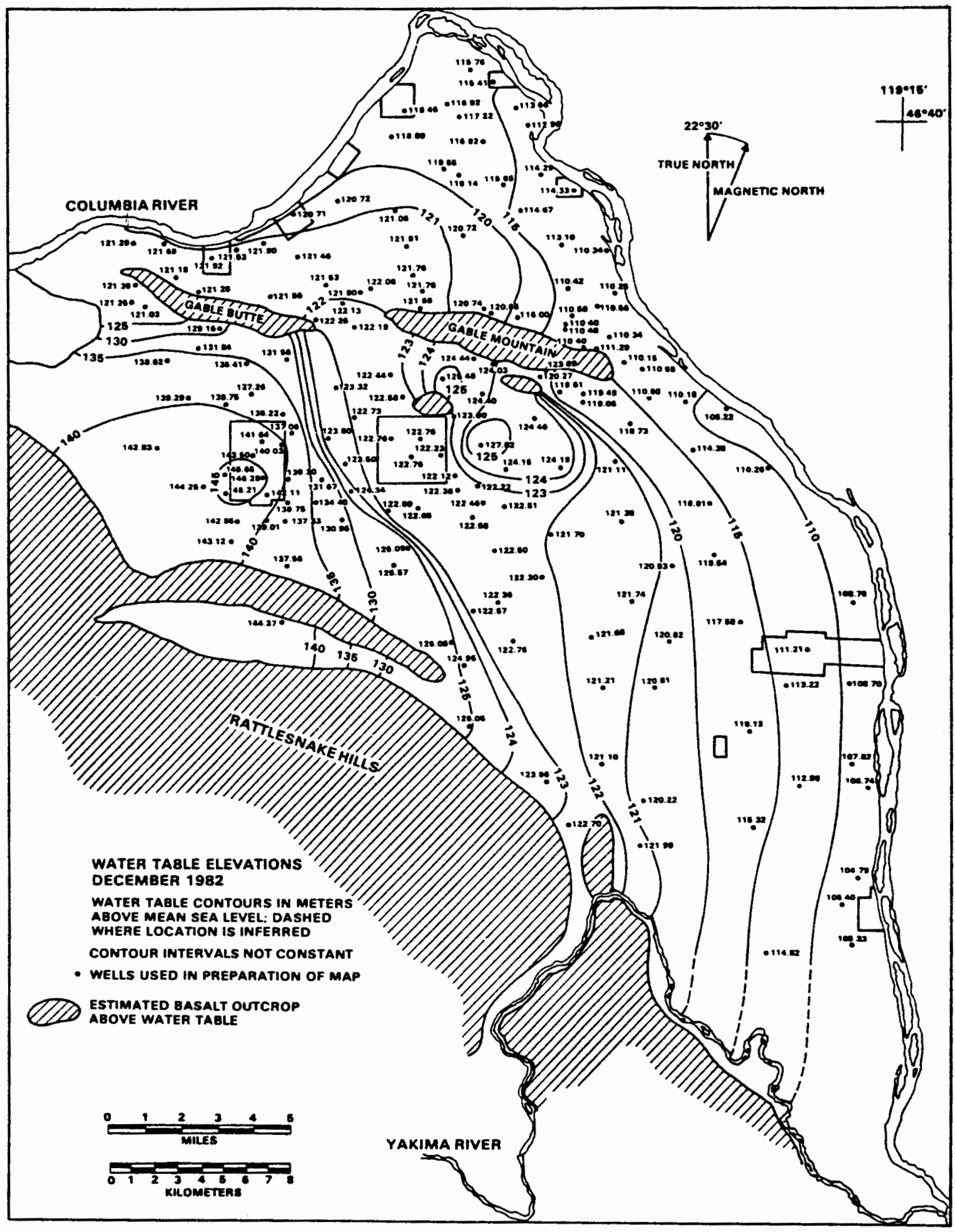

Figure A.1. Water table map of the Hanford Site (modified from Graham, 1984). 


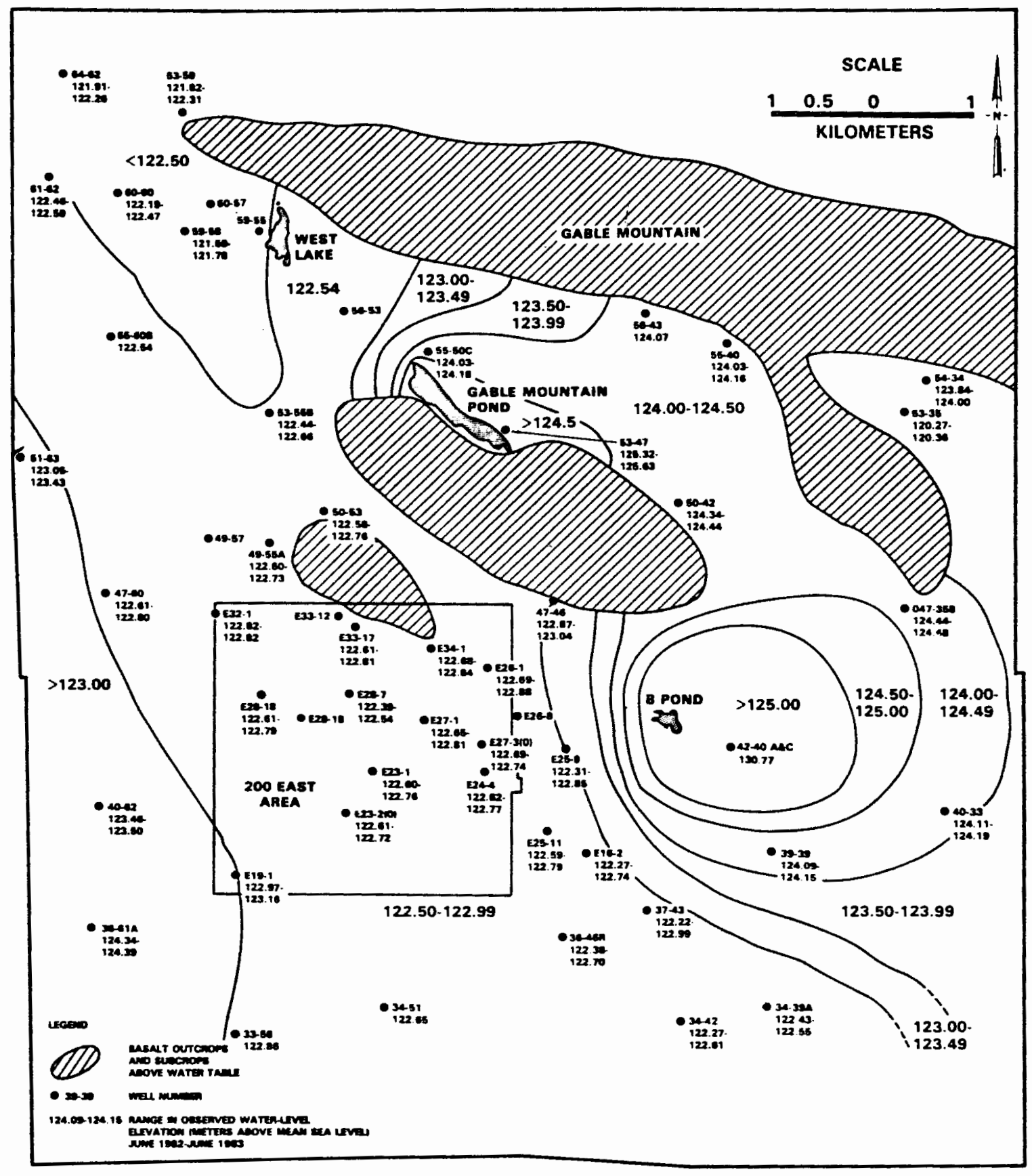

Figure A.2. Water table map of the Study Area (modified from Graham, 1984. 
calibration) of transmissivity and aquifer bottom values was conducted in 1982 (Eddy et al., 1982). These properties were revised for this study.

Newly acquired well core data from over 400 wells located within the Hanford Site ${ }^{(1)}$ were used to calibrate the unconfined aquifer for this study. This data was extrapolated and digitized to allow a detailed interpretation of the aquifer bottom surface for the Separations Area. A three-dimensional representation of this digitized surface is shown in Figure A.3. Erosional channels and potholes produced from flood waters previously described can be interpreted from the extrapolated surface. The upper basalt surface represents the aquifer bottom through most of the site, with the exception of the southern portion, where a clay layer forms the aquifer bottom. Thickness values of the unconfined aquifer were produced from subtracting this revised aquifer bottom surface from water table elevations (shown in Figure A.2.). Impermeable boundaries were assigned to the unconfined aquifer in areas where the basalt bottom subcrops above the water table. Values of hydrautic conductivity were computed by dividing transmissivity values (Graham, 1981) by the revised thickness surface described above.

Two models of the unconfined aquifer were developed, one of the entire Hanford Site, and a sub-model of the study area. The

(1) Myers, D.A., G.V. Last, and M.D. Freshley, 1985. "Status Report on the Hydrogeologic Conceptual Model for the Unconfined Aquifer of the Hanford Site", unpublished report. 


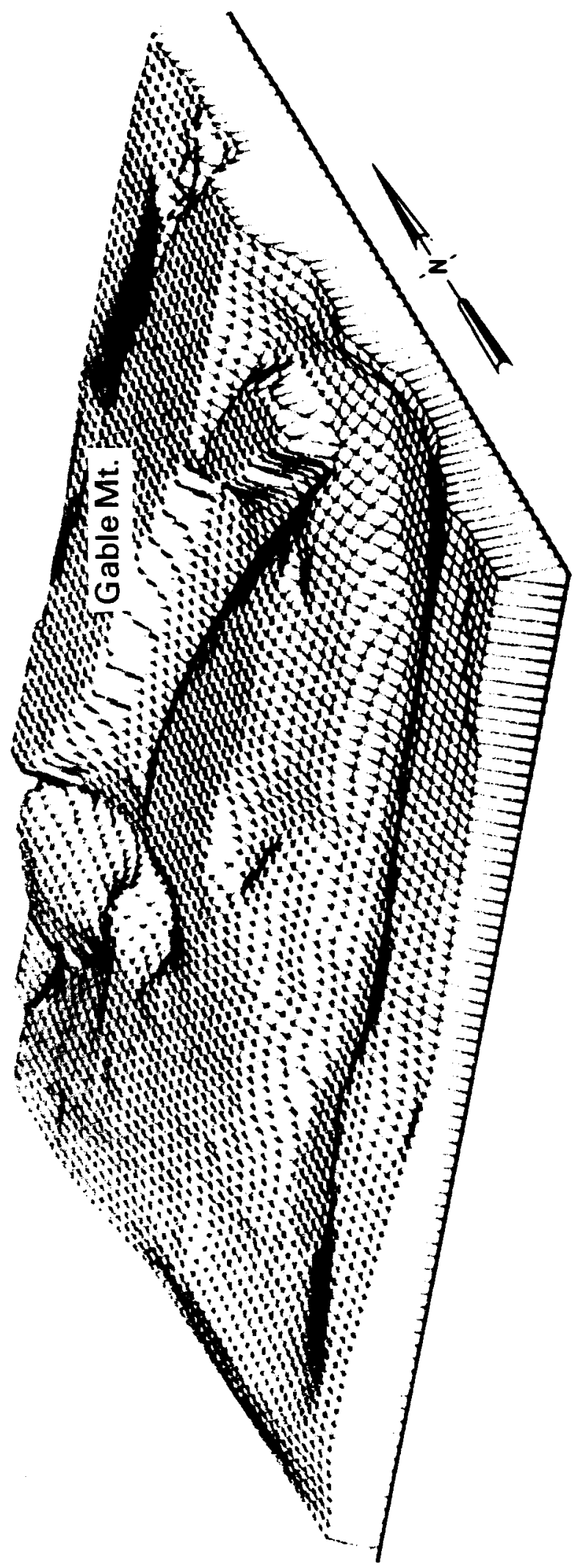

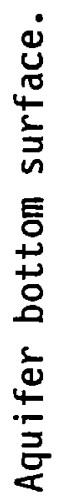

\begin{tabular}{c}
$m$ \\
$\dot{4}$ \\
0 \\
5 \\
0 \\
\hdashline
\end{tabular} 
finite difference model of the Hanford Site was composed using existing data and newly revised hydraulic conductivity and aquifer thickness values described above. An existing grid of the Hanford Site model (Kipp et al., 1972) was used. Each rectangular element of the two-dimensional model has a grid space of 610 meters (2000 feet). Natural boundaries are the Columbia and Yakima River (specified held head), bedrock (impermeable, zero flux) where the basalt rises above the water table, and recharge at aquifer boundaries from irrigation (constant flux). These boundaries are shown in Figures A.1. and A.4. Steady state hydraulic heads were solved using the VTT code.

A sub-model characterizing the study area was constructed by first reducing this Hanford Site grid as shown in Figure A.4. Since few natural boundaries occur for the unconfined aquifer in the study area, boundaries were derived from the larger Hanford site model. This was accomplished by assigning potential values along the perimeter of the study area, as shown in Figure A.4., derived from the solution of the larger Hanford Site model. These boundary potentials do not change in the simulation process, hence are commonly called "held head" boundaries and represent Dirichlet boundary conditions. The northern portion of the study area has natural impermeable boundaries (Gable Mountain). "Zero-flux" boundaries are assigned to this impermeable zone.

Hydraulic heads (potentials) were solved within the study area using the VTT code. The simulation was evaluated by comparing the resulting potentials with observed data. The difference between the 


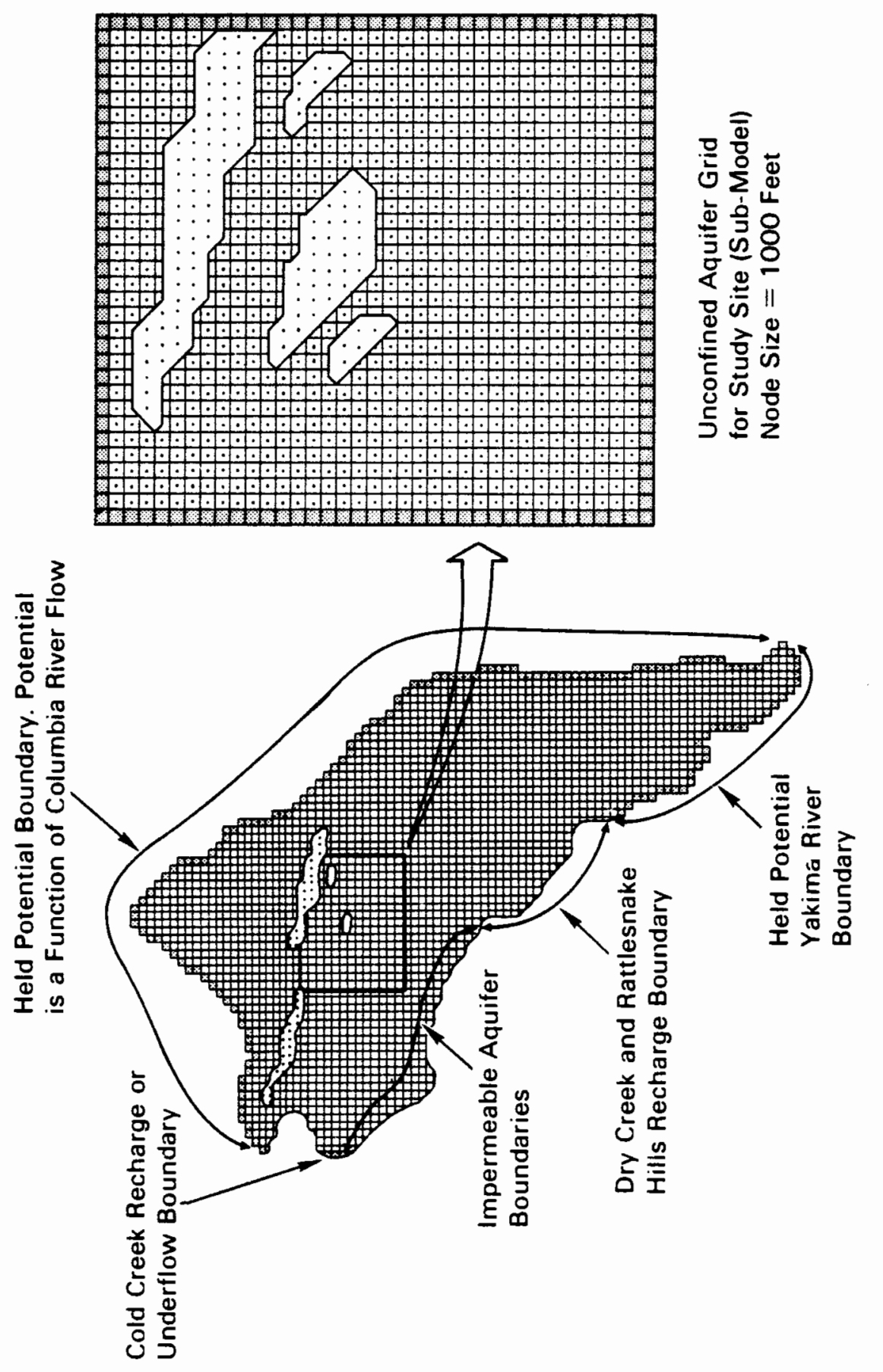

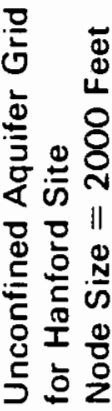

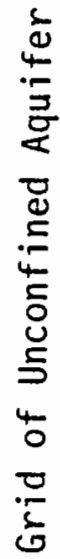

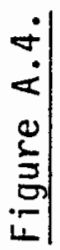

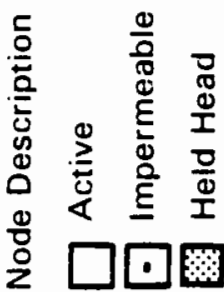


results and the observed (referred to as an error) were recorded as a means for quantifying the quality of the simulation. Results were excellent (i.e., low errors) in most of the site, except in two areas, south of Gable Mountain and in the vicinity of B Pond. The hydraulic conductivity was adjusted in these two problem areas in an attempt to reduce the errors. Reductions in the hydraulic conductivity in the $B$ pond area improved the resulting potentials. Adjustment of the hydraulic conductivity in the vicinity south of Gable Mountain however, did not improve results in that region. Perhaps the sandwiching effect of the basalt ridges is to blame for the difficulty of calibrating this area. Figure A.5. shows the errors of 51 well locations associated with this calibrated run.

The resulting potentials from this run were used in leakage calculations described in this study. Potentials along the perimeter of the study area (derived from the regional model) were used for estimating boundary conditions for the confined aquifer. 


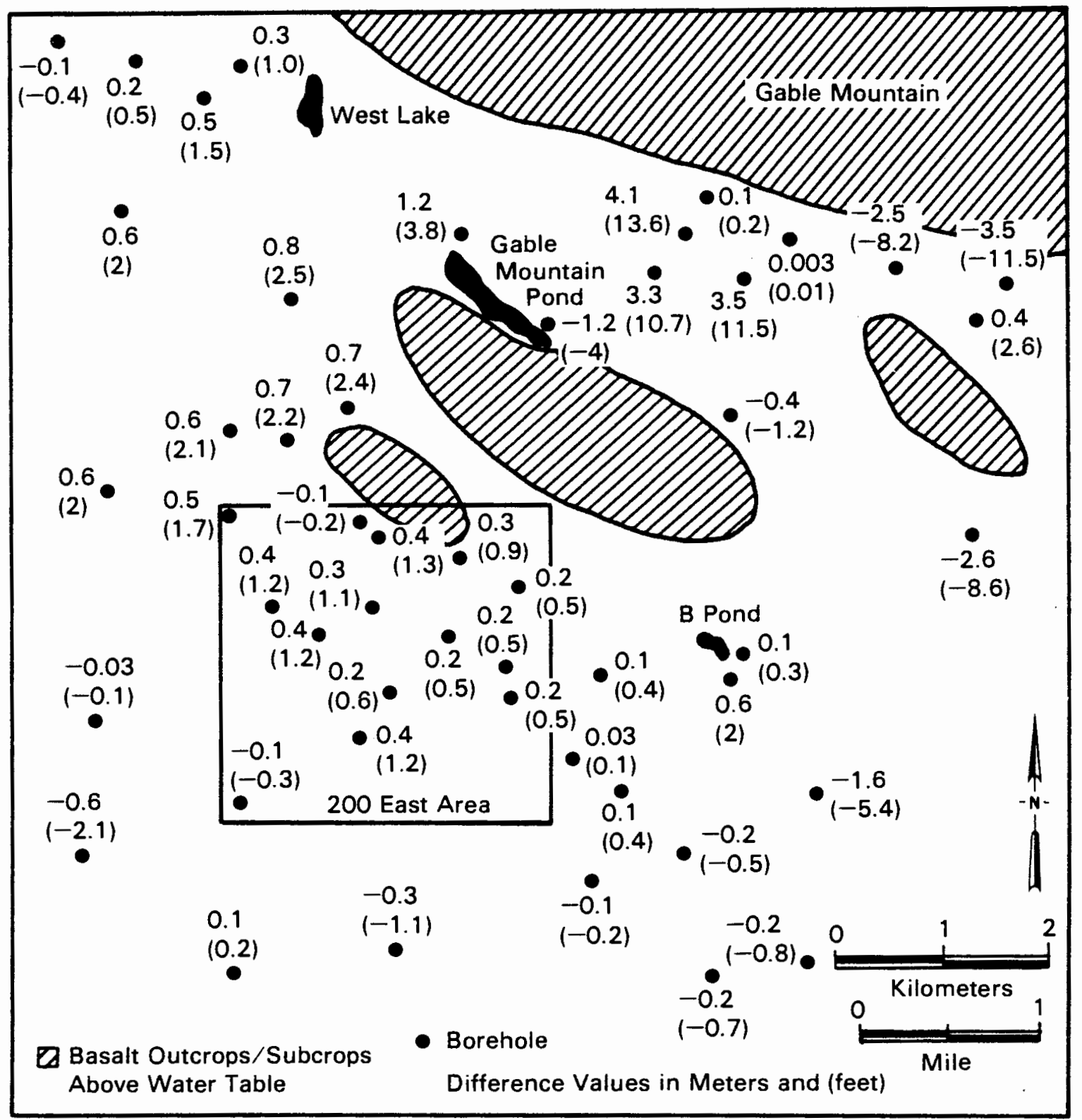

Figure A.5. Residual error of unconfined model's results. 
APPENDIX B

NUMERICAL AND MATHEMATICAL MODEL 
The mathematical model in this study translates the physical characteristics described in the conceptual model into a set of differential equations. The derivation of these equations are based on Darcy's law and conservation principles.

CONTINUITY EQUATION FOR STEADY STATE FLOW

Darcy's law, based on empirical evidence, describes the physics of groundwater flow. It is written in differential form for each of the $x, y$, and $z$ components of three-dimensional flow as:

$$
\begin{aligned}
& q_{x}=-k_{x} \partial h / \partial x \\
& q_{y}=-k_{y} \partial h / \partial y \\
& q_{z}=-k_{z} \partial h / \partial z
\end{aligned}
$$

where

$q=$ specific discharge or Darcy velocity $(1 / t)$

$K=$ proportionality constant or hydraulic conductivity $(1 / t)$

$h=$ hydraulic head

$\partial h / \partial x, \partial h / \partial y, \partial h / \partial z=$ components of head drop over distances $x, y, z$ (unitless)

The differential equations governing groundwater flow for steady state conditions can be derived from a physical point of view using principles just described.

Conservation of mass states that there can be no net change in the mass of a fluid contained in a small volume of an aquifer. 
Therefore, this requires that the volume of water flowing into a representative elemental volume (i.e. the cube pictured below in Figure B.1.) equal to the volume flowing out. A change in mass flowing in must then be balanced by a change flowing out. The discharge $Q$, is a product of the flow rate per unit area and the area of the face from which flow occurs. Therefore:

$$
\begin{aligned}
& Q_{x}=\left[\left(\partial q_{x} / \partial x\right) \Delta x\right] \Delta y \Delta z \\
& Q_{y}=\left[\left(\partial q_{y} / \partial y\right) \Delta y\right] \Delta x \Delta z \\
& Q_{z}=\left[\left(\partial q_{z} / \partial z\right) \Delta z\right] \Delta y \Delta x
\end{aligned}
$$

where

$$
\begin{aligned}
& Q=\text { discharge }(13 / t) \\
& q=\text { specific discharge over face of cube which flow occurs }(1 / t) \\
& x, y, z=\text { lengths of cube }(1)
\end{aligned}
$$

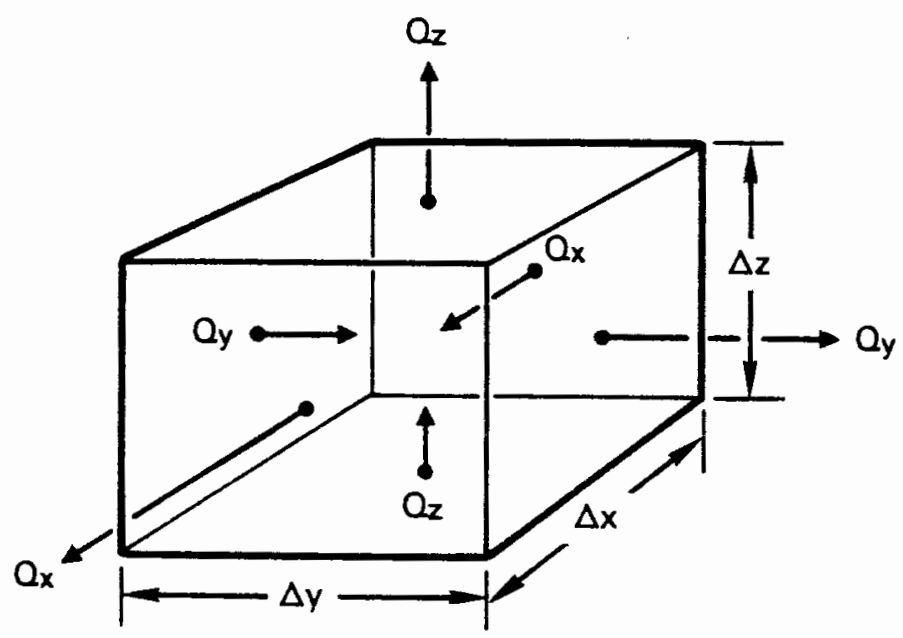

Figure B.1. Representative elemental volume cube 
Setting the sum of all discharges to zero (conserving mass) and dividing through by the volume $(x, y, z)$, we are left with:

$$
\partial q_{x} / \partial x+\partial q_{y} / \partial y+\partial q_{z} / \partial z=0
$$

substituting Darcy's 1 aw into equation 1 gives:

$\partial / \partial x(-K \partial h / \partial x)+\partial / \partial y(-K \partial h / \partial y)+\partial / \partial z(-K \partial h / \partial z)=0$

Assumptions:

1. head is independent of time

2. water is incompressible

3. volume contains no sources or sinks

4. principal components of the hydraulic conductivity tensor are oriented with the $x, y, z$ directions

5. aquifer is isotropic

6. system is everywhere saturated with liquid at all times

7. flow system is confined

Since this study allows water to be added and removed from the aquifer (e.g. Teakage, recharge), a source/sink term is incorporated in equation 2 by setting the right hand side equal to the addition or withdrawal of groundwater (see equation 3 ).

If flow is essentially horizontal such that the vertical component of flow ( $z$ ) is considered minimal, a two-dimensional representation of the actual three-dimensional aquifer can be assumed:

$$
\partial / \partial x(-K \partial h / \partial x)+\partial / \partial y(-K \partial h / \partial y)=R(x, y)
$$


where

$R=$ source or sink term

Leakage through semi-permeable confining layers was

incorporated into the source/sink term (Bredehoeft and Pinder, 1970):

$$
q=\left(-k_{e} / m\right) A\left(h_{1}-h_{2}\right)
$$

where

$q=$ interaquifer transfer flux $\left(1^{3} / t\right)$

$\mathrm{Ke}=$ effective transfer conductivity (vertical hydraulic conductivity of confining layer, i.e. Elephant Mountain Member in this study) $(1 / t)$

$\mathrm{m}=$ effective thickness (of confining layer) (1)

$A=$ nodal area $\left(1^{2}\right)$

$h_{1}, h_{2}=$ hydraulic potentials in the upper and lower aquifer (1)

$-\mathrm{Ke} / \mathrm{m}(1 / \mathrm{t})$ is referred to as the interaquifer transfer

coefficient (Variable Thickness Transient code users manual), and when multiplied by $A$, it represents the interaquifer transfer coefficient per node $\left(1^{2} / t\right)$.

NUMERICS

The Variable Thickness Transient (VTT) code (used in this study) utilizes the finite difference technique in transforming the differential equations, previously described, into a large set of coupled algebraic equations.

The finite difference approximation to Laplace's (two-dimensional) equation (equation 2 with constant $K$ ) can be 
derived by considering the function plotted below (Figure B.2.) and a regularly spaced grid.

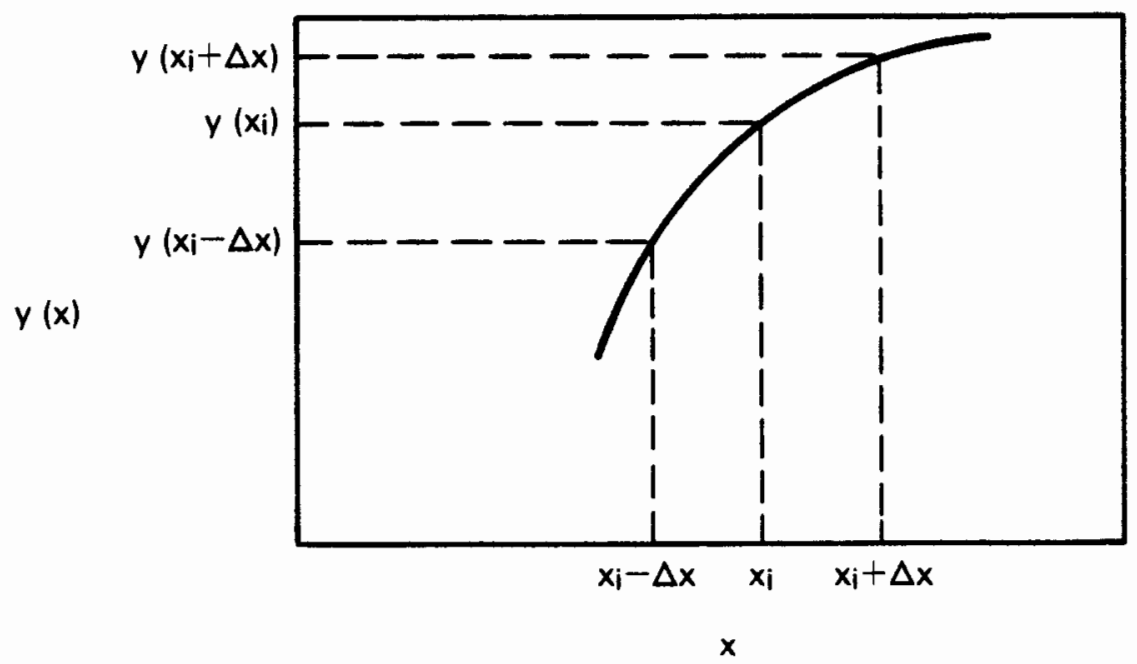

Figure B.2. Function plot

To approximate the function above, the basic definition of the derivative at $x_{j}$ is given as:

$$
\mathrm{dy} / \mathrm{dx} \mid \mathrm{x}_{j} \approx \lim _{\mathrm{x}+0}\left[y\left(\mathrm{x}_{i}+\Delta \mathrm{x}\right)-y\left(\mathrm{x}_{j}\right)\right] / \Delta \mathrm{x}
$$

The central difference approach is common way to express the approximation of the derivative above. This method approximates the derivative as the difference between two points that are separated by $2 \Delta x$ :

$$
\begin{gathered}
d y / d x \mid x_{i} \approx\left[y\left(x_{i}+\Delta x\right)-y\left(x_{i}-\Delta x\right)\right] / 2 \Delta x \\
d^{2} y / d x^{2} \approx 1 / 2
\end{gathered}
$$


In the finite difference approximation, the derivative is estimated by the differences between nodal points in the configuration given below (Figure B.3.).

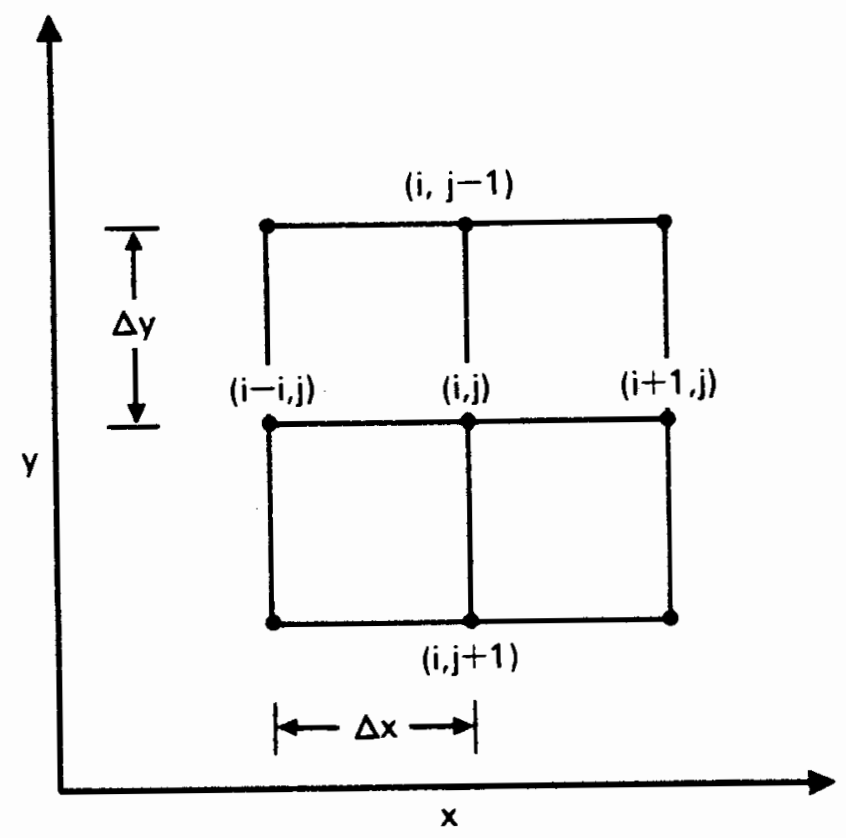

Figure B.3. Finite difference grid

The central difference method estimates $\partial^{2} h / \partial x^{2}$ (see equation 2) by taking the first derivative as the difference between the head values at $(i, j)$ and $((i+1), j)$ and the difference between $(i, j)$ and $((i-1), j)$ and lastly taking the difference between the two derivatives:

$$
\partial^{2} h / \partial x^{2} \approx \frac{\frac{h_{i+1, j}-h_{i, j}}{\Delta x}-\frac{h_{i, j}-h_{j-1, j}}{\Delta x}}{\Delta x}
$$

which simplifies to:

$$
\partial^{2} h / \partial y^{2} \approx \frac{h_{i, j-1}-2 h_{i, j}+h_{i, j+1}}{(\Delta x)^{2}}
$$


and likewise for the $y$ component:

$$
\partial^{2} h / \partial y^{2} \approx \frac{h_{i, j-1}-2 h_{i, j}+h_{i, j+1}}{(\Delta y)^{2}}
$$

As stated previously, the continuity principal requires that changes in mass flowing in and out of a unit volume must balance out. Therefore, the combination of the two derivatives listed above must equal zero:

$$
\frac{h_{i+1, j}-2 h_{i, j}+h_{i-1, j}}{\Delta x^{2}}+\frac{h_{j, j-1}-2 h_{i, j}+h_{i, j+1}}{\Delta y^{2}}=0
$$

If $\Delta x=\Delta y$, and combining terms, the generalized form of the finite difference approximation states:

$$
h_{i+1}-4 h_{i, j}+h_{j-1, j}+h_{i, j-1}+h_{i, j+1}=0
$$

and forms the basic framework for the VTT code.

By incorporating the source and sink terms and given boundary conditions that make the model unique, this equation solves for the head (the unknown) at node $i, j$. In this manner, an equation for each node (unknown) is derived. These sets of linear equations are simultaneously solved by the Cholesky decomposition technique. Details on this common elimination method are described in most numerical method textbooks (James et al., 1985, for example). 
MODEL GRID

A finite difference grid was developed by superimposing a system of 1023 nodal points over the study area's domain as shown in Figure B.4. Lattice points were spaced equidistanced apart, with $\Delta x$ $=\Delta y=305$ meters (1000 feet).

Boundary conditions assigned to the confined aquifer consisted of either held head or zero flux (impermeable). Held head values, assigned along most of the perimeter of the study area, were derived from the regional unconfined aquifer model. A detailed description of this derivation is included in Chapter 3, Model Strategy and Assumptions. Impermeable boundaries were assigned to nodes containing Gable Mountain, located in the northern portion of the site.

Potentials of the unconfined aquifer (see Appendix A) were used for computing head differentials, which are input parameters in the leakage calculations (described in the calibration section). In summary, the unconfined aquifer was treated as a held head surface (see Figure B.4.). At each node, a head differential was computed by taking the difference between this held head potential and the potential resulting from the confined aquifer simulation. 

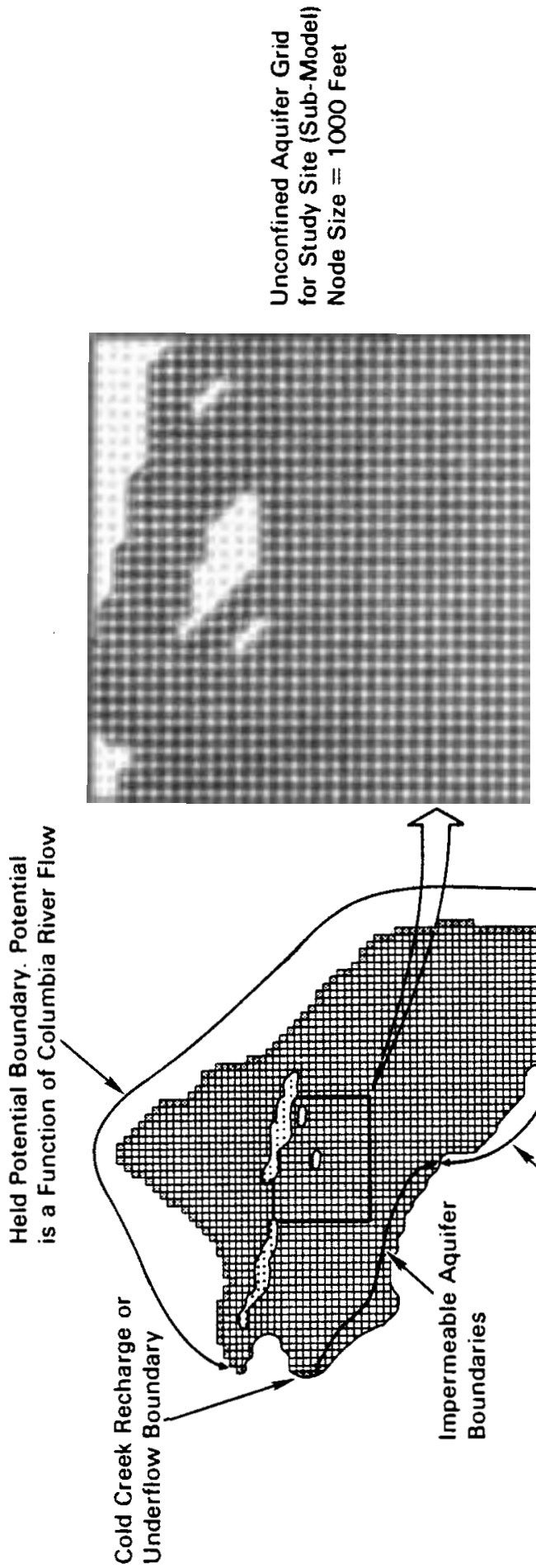
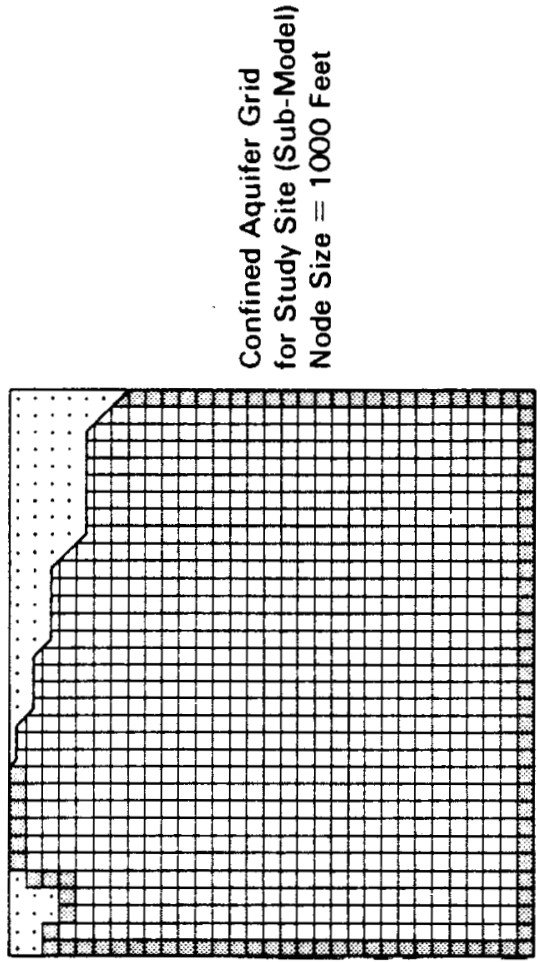

$\frac{n}{5}$
$\frac{1}{5}$
$\frac{1}{2}$

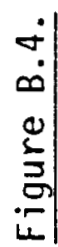

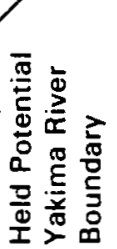

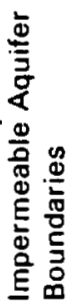

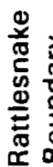

등

웡

๘

논

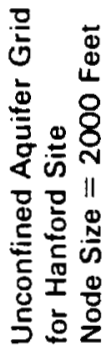

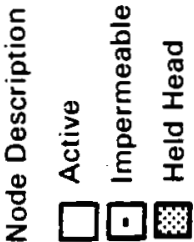


APPENDIX C

GLOSSARY 
Aquifer Pump Test: A test to determine hydraulic characteristics of an aquifer by pumping a well and observing the change in hydraulic head of the aquifer.

Aquifer Intercommunication: The hydrologic mixing of two or more aquifers.

Aquifer: Saturated porous rock or sediment.

Borehole: Well drilled for exploratory work.

Boundary Condition: In groundwater modeling, boundaries may by physical (impermeable, specified flux, or constant head) or derived from a larger model (e.g., taken from a model with physical boundaies assigned, and then held constant). These boundaries, which are translated into mathematical terms, are required by Laplace's equation to constrain the problem and make solutions unique.

Conceptual Model: Contains the understanding of the aquifer system's physical makeup.

Condition: Referred to in this study as a variation on the value assigned to a model component (see table 5).

Constant Flux Boundary: see Specified Flux

Constant Head Boundary: see Held Fotential Boundary

Darcy's Law: A law based on empirical evidence that describes the physics of groundwater flow.

Discharge Area: Region where water is withdrawled.

Disposal Pond: Natural or diked surface depression which allows liquid effluent to percolate into the underlying sediment. Effluent consists mainly of cooling water and steam condensates from chemical processing facilities. The major disposal ponds in the study area are Gable Mountain Pond and B Pond.

Dupuit Assumption: The assumptions that (a) the hydraulic gradient is equal to the slope of the watertable, which is assumed small and (b) flow is horizontal.

Equipotential line: A line mapped of equal hydraulic head values.

Grid (finite difference): A translation of a given continuous aquifer to a simplified network of points, when connected forms a pattern of rectangular cells. Each cell, also referred to as a node, represents a uniform hydrogeological distribution. Solving a flow equation for each node yields a solution for the unknown variable. The grid spacing defines the size of each node and hence the spatial resolution of the model and its solution. 
Head Differential: The difference of head values. In this study the term commonly refers to the difference between the heads of the unconfined and confined aquifers.

Held Potential Boundary: A type of boundary condition where head is known or approximated across a surface (also referred to as a Dirichlet Condition, Held Head, or Constant Head).

Hydraulic Conductivity: A coefficient of proportionality defining an aquifer's ability to transmit water. Effective Hydraulic Conductivity in this study is referred to as the conductivity in the direction of expected flow, e.g. in the confining bed, the direction is vertical.

Hydraulic Gradient: The ratio of the change in head and the change in distance in a given direction.

Interaquifer Transfer Coefficient: A coefficient which when multiplied by the vertical head differential yields the flow quantity being transferred between two aquifers separated by a semi-permeable confining layer. The coefficient's value is computed as the vertical hydraulic conductivity (effective) divided by the thickness of the confining layer.

Impermeable Boundary: see No-Flow Boundary

Mathematical Model: Translates the physical characteristics of the conceptual model into continuous differential equations based on principles of conservation of mass and Darcy's Law.

Model Component: A constituent of the physical makeup of a model. Values are assigned to these constituents to define the geohydrological setting. Examples of model components in this study are: source term, interaquifer transfer coefficient, hydraulic conductivity, and boundary conditions (see table 5).

Model Calibration: A process that involves the adjustment of geohydrological parameters, so that the model output reasonably agrees with observed field data.

Mound (ground water): Elevated potentiometric surface.

No-Flow Boundary: A groundwater divide or an impermeable barrier to groundwater flow. Also called zero flux or impermeable boundary.

Numerical Model: Transforms the differential equations of the mathematical model into a large set of coupled algebraic equations, which can then be solved on a digital computer.

Potential/Potentiometric Surface: The surface that represents the level of which water will rise in a well. Also referred in this study to head, head potential, hydraulic head, and piezometric 
surface. Observed (field) potential is used in this study in reference to values measured from well readings, while modeled potential is used in reference to resulting values from a computer simulation. It has units of length.

Recharge Area: Region where water replenishs an aquifer.

Residual (error): A means of quantifying the validity of a modeled potential surface. In this study the error is calculated as the standard deviation of the difference between the modeled head differentials and the head differential values as interpreted from observed data.

Sensitivity Analysis: The sensitivity of a groundwater system to its hydrologic properties and boundary conditions. Testing involves evaluating the response of the system to variations on values assigned to selected properties.

Separations Area: Major liquid waste disposal location for the Hanford Site. Gable Mountain Pond and B Pond contain the largest volumes of liquid effluent.

Simulation (run): The combination of all necessary input variables that describe a given scenario. Results of a simulation consist of values of an unknown variable (the solution).

Source Term: The recharge term of Poisson's equation. It has units of length per unit time.

Specified Flux: Recharge boundary to a surface that recives a constant rate of groundwater flow. Also referred to as constant flux.

Steady State: A condition that states that the hydraulic heads in the system are independent of time, which implies a state of equilibrium.

Storage Coefficient: The volume of water an aquifer releases from or takes into storage, per unit surface area of the aquifer per unit change in head. Unitless.

Transient: A condition that states that the hydraulic heads in a system are dependent of time. This implies a state of disequilibrium.

Transmissivity: Describes the transmittance of water through an aquifer as a function of both the hydraulic conductivity and the thickness of the aquifer. It has units of length squared per unit time.

VTT (Variable Thickness Transient): A set of computer codes that 
uses the finite difference method to simulate groundwater flow in two-dimensions.

Water Table: The surface of an unconfined aquifer.

Zero Flux: see No-Flow Boundary. 